\title{
الثقة التنظيمية ودورها في تطوير الأداء الوظيفي للعاملين بالجامعة
}

\author{
إعداد \\ د/ مروة جبرو عبد الرحمن \\ د/ هنية جاد عبد الغالي \\ مدرس أصول التربية \\ مدرس أصول التربية \\ كلية التربية- جامعة أسوان. \\ كلية التربية- جامعة أسوان.
}




\section{الثقة التظيمية ودورها في تطوير الأداء الوظيفي للعاملين بالجامعة \\ ملخص البحث}

استهدف البحث تقديم مجموعة من التوصيات التي من شأنها أن توضح

دور الثقة التظظيمية في تطوير الأداء الوظيفي للعاملين بجامعة أسوان ، وذلك ملك من خلال رصد واقع الأداء الوظيفي وواقع دور التقة التتظيمية بجامعة أسوان ، استخدم البحث المنهج الوصفي (المسحى - التحليلي)، والاستبانة كأداة لجمع البيانات من عينة البحث التي تمثلت في عينة من (العاملين) بجامعة أسوان بلغ قوامها (ب. (r) ، وتوصلت نتائج البحث إلي أن هناك قصوراً في الأداء الوظيفي للعاملين بجامعة أسوان، وبِ النهاية قدم البحث مجموعة من التوصيات التي من شأنها توضح دور الثقة التظيمية في تطوير الأداء

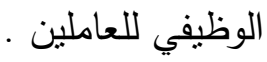
الكلمات المفتاحية: الثقة التتظيمية- الأداء الوظيفي.

\section{Abstract}

The research aimed at presenting a set of recommendations that would indicate the role of organizational trust in the development of the job performance of the employees of Aswan University, by monitoring the reality of the job performance and the reality of organizational confidence role in Aswan University. The research used the descriptive- (205). The results of the research revealed that there is a shortage of job performance for the employees of Aswan University. Finally, the research presented a set of recommendations that will clarify the role of organizational trust in performance development. Career for both Laxative.

Keywords: Organizational Trust - Functionality. 
تتشهر المجتمعات الحديثة على إختلاف أنواعها تزايداً مضطرداً في عدد وحجم المؤسسات التي توفر الخدمات الضرورية للمجتمع، وتعتمد هذهات التهات المؤسسات على متخصصين يفترض فيهم القيام بعملهم بطرق تتسم بالفاعلية،

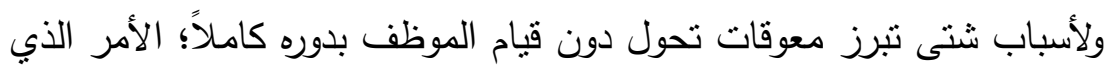

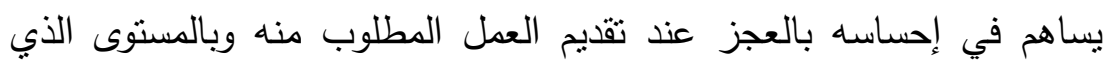
يتوقعه منه الآخرون. ومنى ما حدث ذلك فان العلاقة التي تربط الموظف بالمؤسسة تأخذ بعداً سلبياً له آثاره السيئة على الآلى الفرد والمؤسسة والعملية

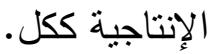

والجامعات من أهم المؤسسات التي تؤدي دوراً فاعلاً وهاما في عملية

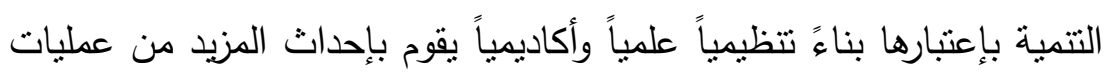

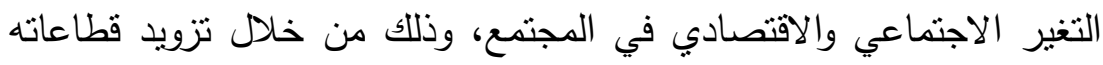

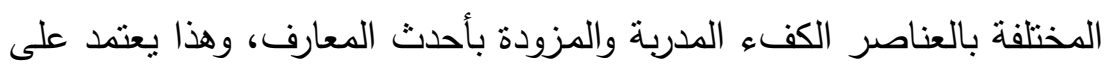
كفاءة وفاعلية العاملين بالجامعة.

وما يشهده العالم هذه الأيام من تتافس يتطلب من الجامعات التركيز على

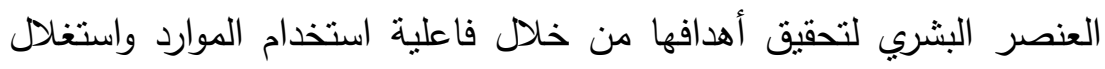
الفرص المتاحة والطاقات المتوفرة لتحقيق مستوي أعلي من الأداء، كل هذه

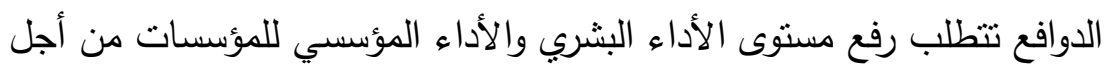
تقديم الخدمات بسرعة وجودة عالية، وذلك من أجل الاستجابة لاحتباجات وتوقعات العاملين (البلوي، م ـ . ب). 
حيث تزايد الإهتمام في الوقت الحاضر بموضوع الأداء وبمدى فاعلية وكفاءة المؤسسات في تأدية وظائفها، وتحقيق الأهداف التي وجدت من أجلها،

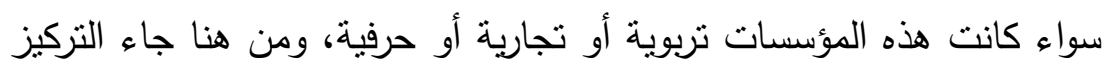

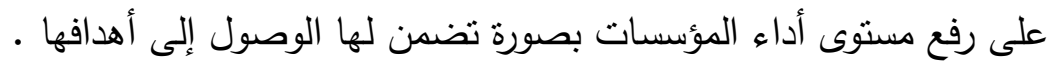
حيث ينظر للأداء على أنه من العمليات الأساسية، التي لا بد من الإهتمام بها عند التفكير ، والتخطيط لعمليات النطوير في الجامعة، فمن خلاله

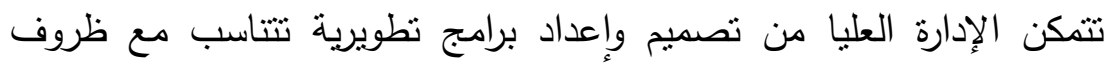

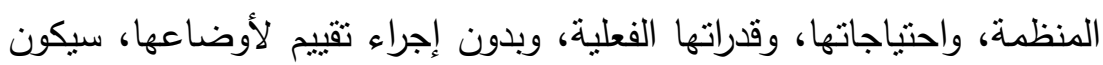

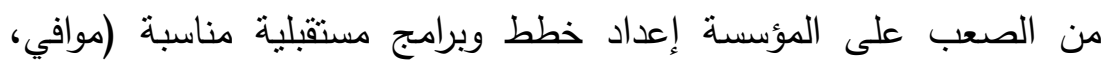
. (0. r. T. V

كما أن الأداء الوظيفي يحتل مكانه خاصة داخل أي مؤسسة ، باعتباره

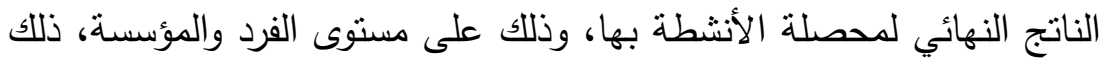
أن المؤسسة تكون أكثر استقرارا وأطول بقاء حين يكون أداء العامين أداء لأداء

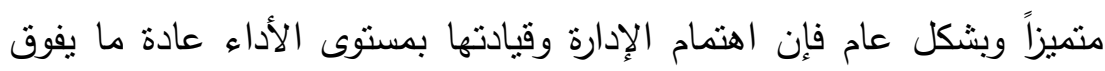

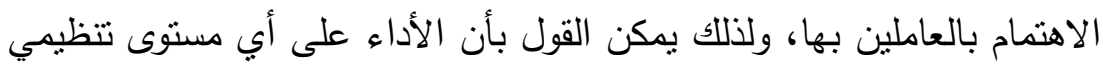

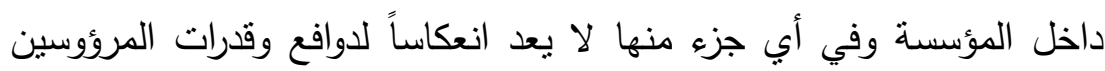
فحسب بل هو انعكاس لدوافع وقدرات الرؤساء والقادة أيضاً (الثريف، ـ ـ . . ب). وإذا كان الأداء الوظيفي هاماً في المؤسسات فإن أهميته تزداد بشكل أكبر

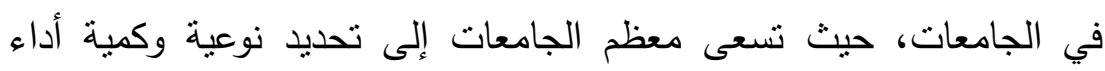

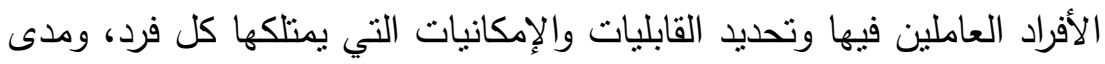
احتياجات الأفراد إلى التطوير . 


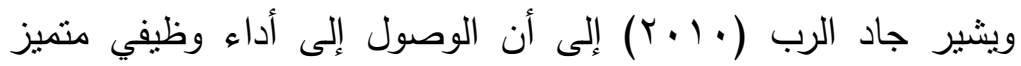

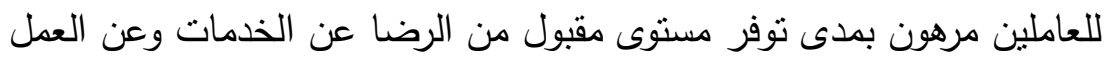
وعن العدالة المادية والمعنوية ولن يتحقق ذلك الرضا إلا بوجود ثقة بين القيادة الإدارية والعاملين بالجامعة.

ولتحقيق ذلك يجب أن تقوم الجامعة بدور مميز في إعداد الكوادر المؤهلة

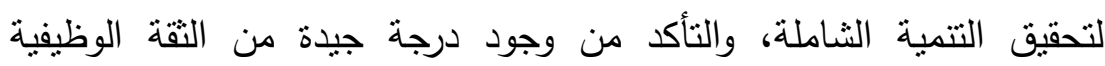
للعاملين فيها، لينعكس ذلك علي تطوير الأداء الوظيفي للعاملين بالجامعة. أسئلة البحث تحددت أسئلة البحث فيما يلي 1 ا ـ ما فلسفة الثقة التظظيمية ؟

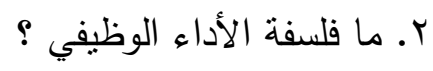
r. ما واقع دور النقة التنظيمية لدي العاملين بجامعة أسوان ودورها في تطوير أداء العاملين؟ ها وافع دور ء. ما التوصيات المقترحة لتفعيل دور الثقة التظظيمية في نطوير الأداء الوظيفي للعاملين بجامعة أسوان؟ أهداف البحث هدف البحث الحالي إلي: - الي - التعـرف علـي فلسـفة التقــة التظظيميـة مـن حيـث المفهـوم والأهميـة والأهداف. - - التعرف علي فلسفة الأداء الوظيفي . 
- الكثـف عـن واقـع الأداء الـوظيفي وواقـع دور التقـة التنظيميـة لـدى -

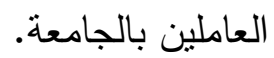
- توضيح دور الثقة التتظيمية في تطوير الأداء الوظيفي للعاملين بكليات

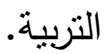

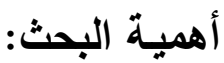

برزت أهمية البحث من كونه سعى إلى التعرف على واقع التقة التظيمية

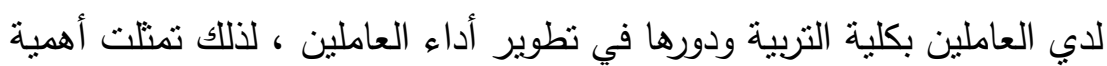

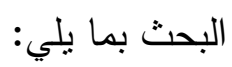

ا. الكثف عن واقع دور الثقة التنظيمية في تطوير الأداء لدي العاملين

$$
\text { بالجامعة. }
$$

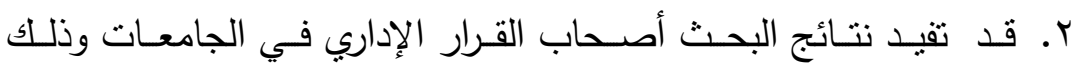
بإعطائهم صـورة واضحة عن الثقة التتظيميـة وعلاقتها بمستوى الأداء

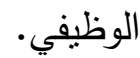

r. يمكن أن تقيد هذه الدراسـة في إثراء الأدب النظري المتعلق بموضدوع

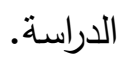

ع. إفادة الباحثين وطلبة الدراسات العليا المهتمين بهذا الموضوع. 0. اكتسب البحث أهمية خاصة من خلال ما طرحه من مقترحات لتوظيف دور الثقة التنظيمية في تطوير أداء العاملين بالجامعة.

$$
\text { تحدد البحث: }
$$


1. الحــدود الموضــوعية: تتـاول البحـث موضـوع التقــة التتظيميـة والأداء

الوظيفي.

r. الحدود البشرية: عينة من العاملين بجامعة أسوان.

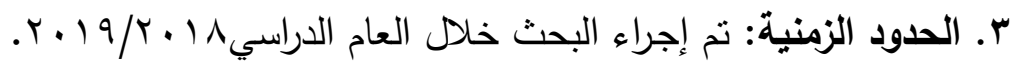

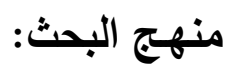

أعتمد البحث علي المنهج الوصفي (التحليلي)، حيث يهنت بدراسة الظاهرة

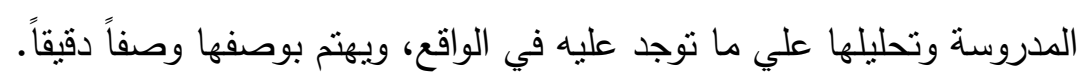

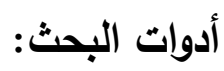

قامتا الباحتان بإعداد إستبانة للتعرف علي واقع دور الثقة التنظيمية في

تطوير أداء العاملين بجامعة أسوان.

مصطلحات البحث :

-

الثقة لغة: هي مصدر وثق ، ويثق ثقة إذا ائتمنه ( الرازي ) ، أوثق الثيء : جعله وثيقاً ، أوثقه : شده بالرباط ، وكذلك الميثاق والمواثقة وهي المعاهدة.

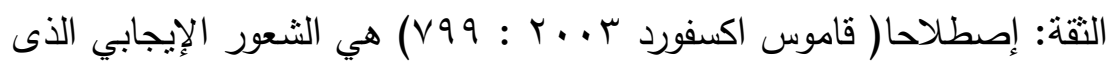

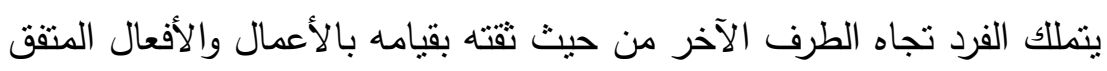

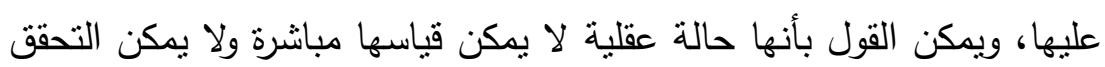

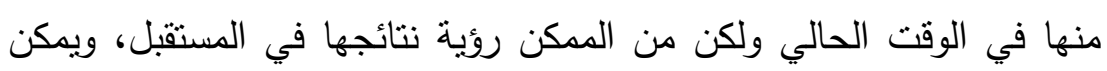
قياسها من خلال التصرف، وهي حركة تتضمن عمل تطوعي بين انثين فيجب التبن

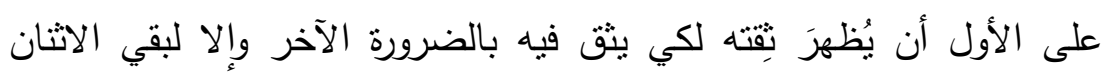
فاقدي الثقة في بعضهما البعض. 
وتعرف الثقة التنظيمية بأنها: إيمان الفرد بأهداف وقرارات المنظمة والسياسات التتظيمية والقائد التظظيمي وبجميع الأفراد العاملين معه في المنظمة التئة

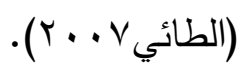
وبذلك تعرف التقة التظظيمية إجرائياً بأنها توقعات متفائلة لأحد الأطراف في

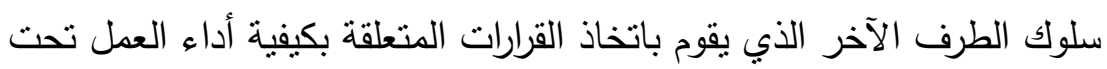

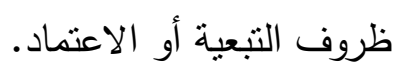

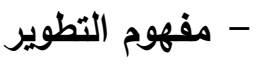

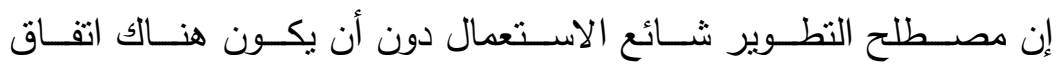

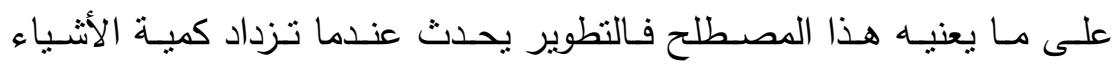
المرغوب فيها والمفضلة نسبيا.

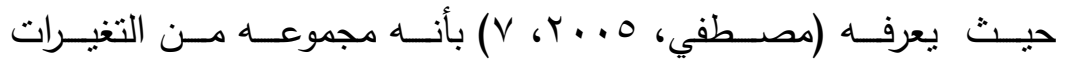

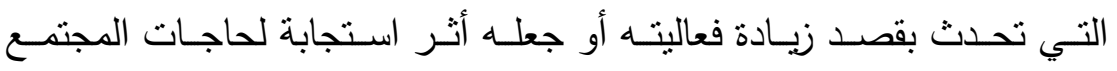
الذي بنشأ فيه.

ويعـرف تطـوير أداء العـاملين :هـي تحسـين الممارسـات التعليميـة التـي

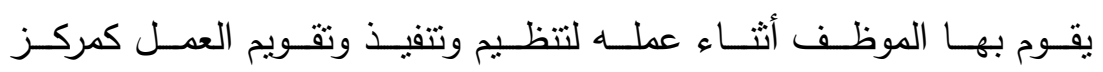

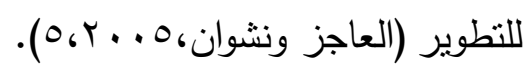

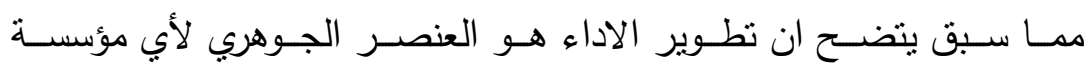
فعالة، وهذا يتطلب مهارات يتعلمها العاملون ويقوم بممارستها.

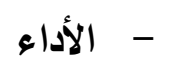

يعرف الأداء : بأنه قيام الفرد بإنجاز الأهداف التي تسعي إليها المؤسسة

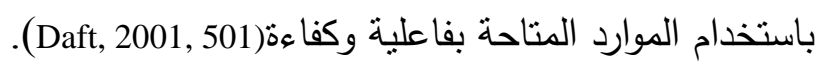


كما يعرف بأنه الإنجاز الذي يتحقق نتيجة ما يبذل في العمل من مجهود

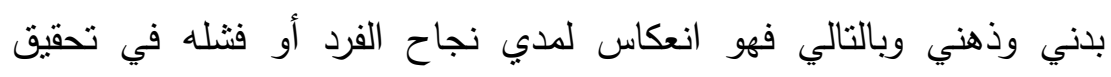

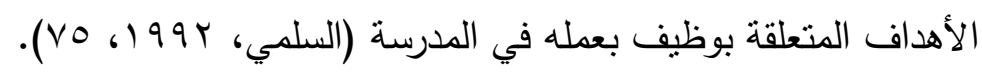

حيث يؤكد هذا التعريف علي أن أداء الفرد يظهر من خلا الإنجاز الذي عاي

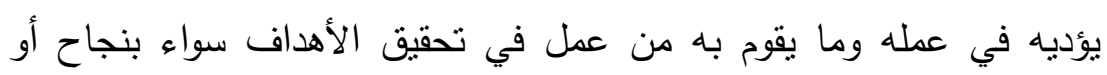
فنثل.

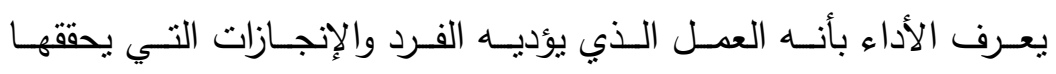

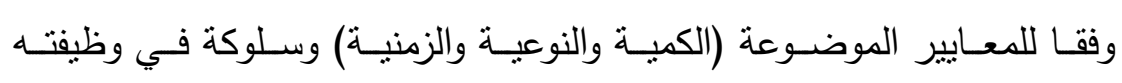

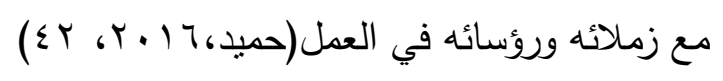

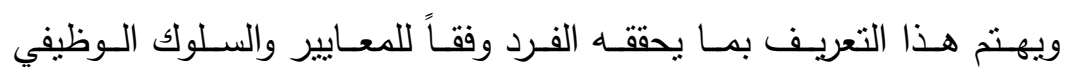
بهدف إنجاز أهداف المؤسسة بفاعلية وكفاءة.

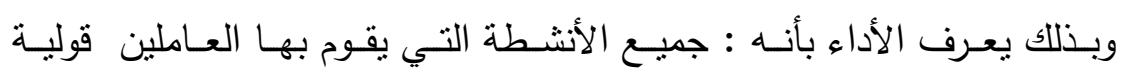

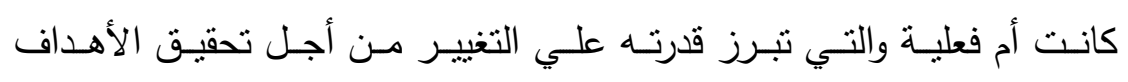
المرسومة. - مان.

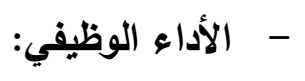

يشير الأداء الوظيفي إلى درجة تحقيق وإتمام المهام المكونة لوظيفة الفرد،

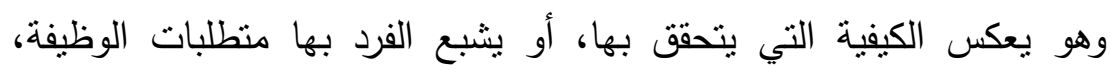

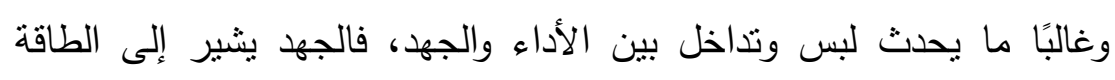
المبذولة، أما الأداء فيقاس على أساس النتائج التي حققها الفرد.

كما يعرف بأنه : مجموعة السلوكيات الإدارية المعبرة عن قبام الموظف المبف

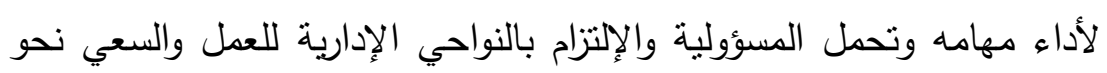

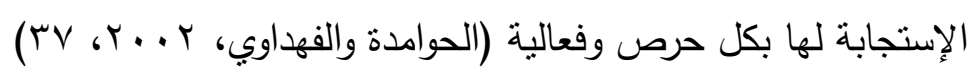


ويعرف إجرائياً بأنه:

قيام العاملين بالجامعة بتتفيذ المهام والواجبات المنوطه بهم وفق الأنظمة والتعليمات المعمول بها في الجامعة وذللك لتحقيق أهداف الجامعة بكفاءة

وفاعلية.

الاراسات السابقة

- أجرى جيمس (James, 2010) دراسة هدفت إلى الكثف عن الثقة

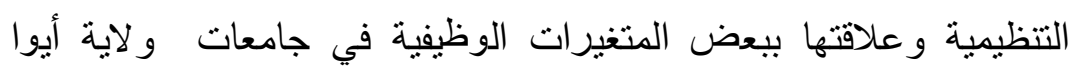

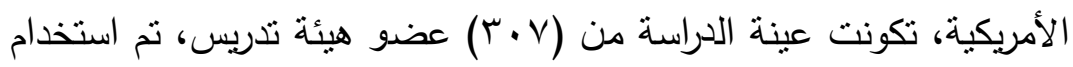

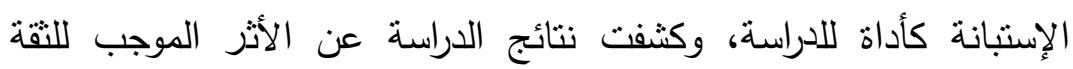
التنظيمية على مستويات عالية من الأداء التنظيمي والتتافسي، والفاعلية النتظيمية والاستقرار والديمومة والإبداع لأعضاء هيئة التنريس.

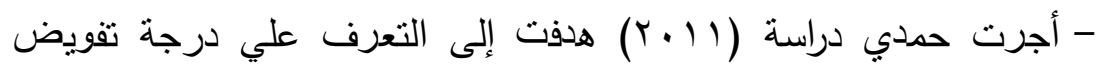

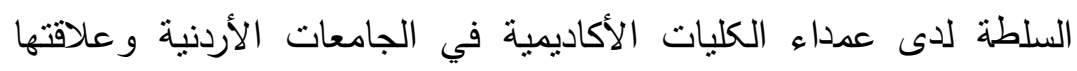

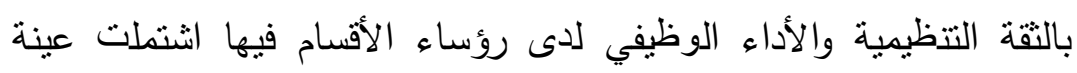

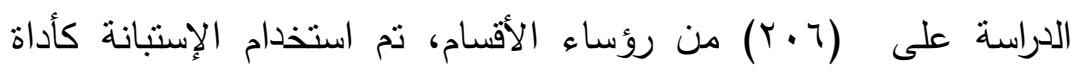

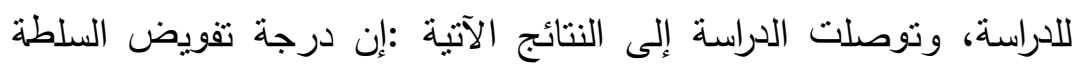

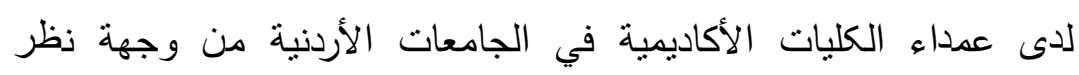

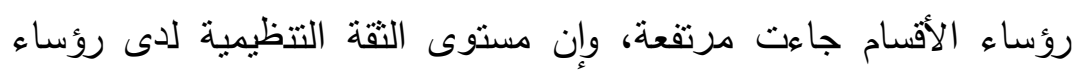

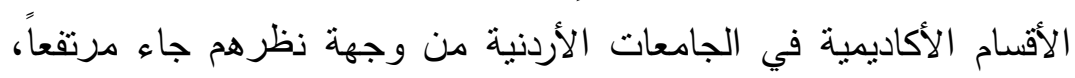

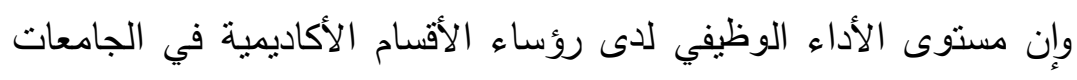


الأردنية من وجهة نظرهم جاء مرتفعاً. كما كثفت النتائج وجود علاقة ارتباطية موجبة بين درجة تفويض السلطة لدى عمداء الكليات الأكاديمية

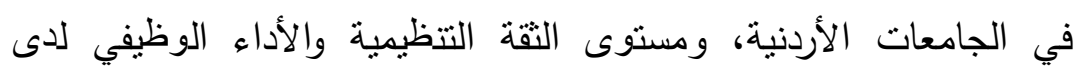
رؤساء الأقسام فيها.

- أجرت هوبز وهويل (Hoppes \& Holley, 2014) دراسة حاولت الكثثف عن العلاقة بين الثقة التتظيمية والمتغيرات المتعلقة بجودة أداء

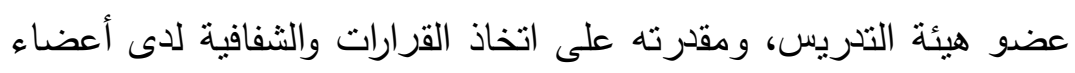

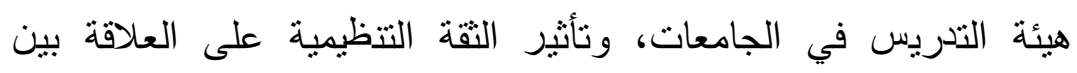

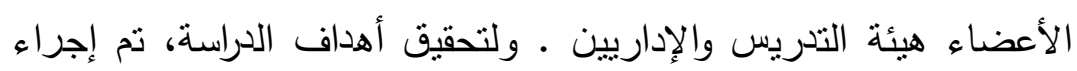

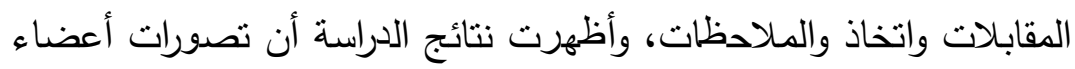

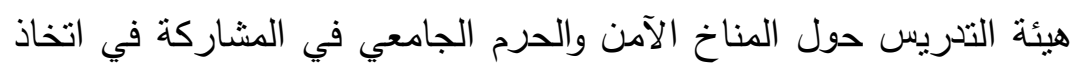
القرارات والثفافية تؤثر إيجاباً في النقة بينهم.

وبناء على ما سبق، يمكن القول بأن الدراسات السابقة تتاولت الأداء

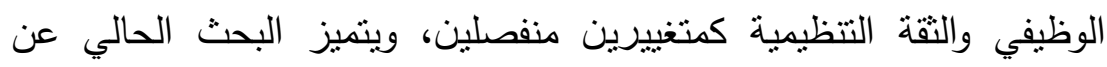
الدراسات السابقة في محاولة التعرف على دور التقة التنظيمية وعلاقتها

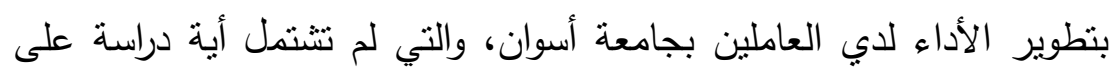
تتاول المتغييرين معاً. إجراءات البحث:

للإجابة عن السؤال الأول: ما فلسفة الثقة التتظيمية ؟ نم تتاول إطاراً فلسفياً عن النقة التتظيمية. r. للإجابة عن السؤال الثاني: ما فلسفة الأداء الوظيفي ؟جم تتاول إطاراً فلسفياً

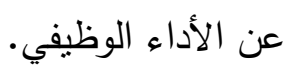


r. للإجابة عن السؤال الثالث: ما واقع دور الثقة التنظيمية لدي العاملين

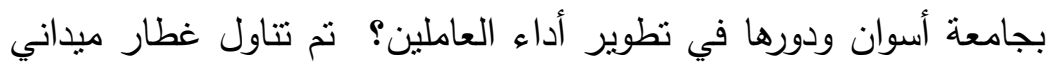

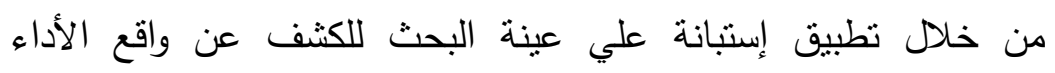
الوظيفي ، وواقع دور النقة التنظيمية لدي العاملين بالجامعة.

ع. للإجابة عن السؤال الرابع: ما التوصيات المقترحة لتفعيل دور النقة

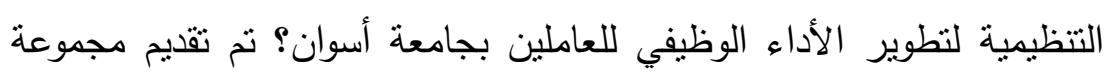

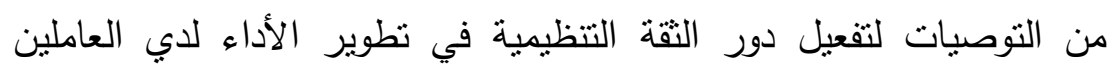

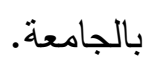

\section{الإطار القلسفي}

أولاً: فلسفة الأداء الوظيفي:

تمهيد:

تعتمد عملية تطوير العملية التعليمية علي مدي تحسين وتطوير مدخلاتها الأساسية، وينعكس تطوير وتحسين أداء العاملين بصورة مباشرة وتطويره وزيادة

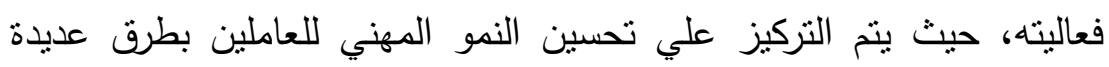

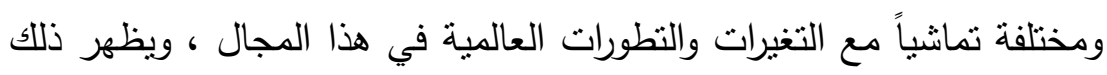
من خلال الدورات التدربيية التي ترتكز بشكل أساسي علي تحسين الأداء.

(1): الأداء الوظيفي: المفهوم والأهمية:

يرتبط مفهوم الأداء بكل من سلوك الفرد والمنظمـة و يحتل مكانـة خاصـة

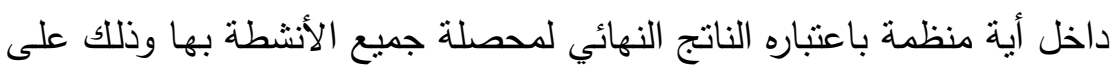

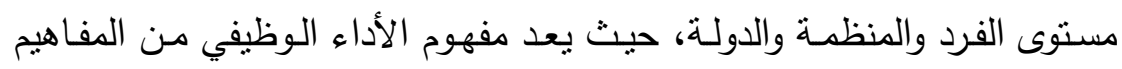

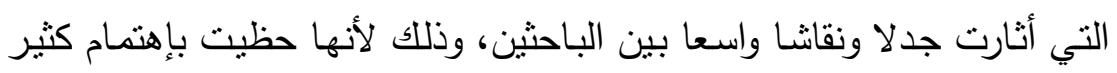


من الباحثن في تخصصات مختلفة مما أدى على اختلافهم في وضع تعريف

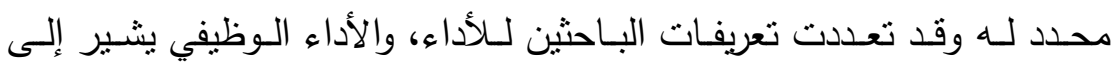

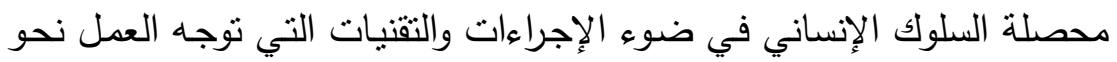

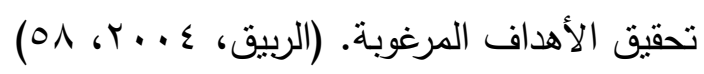

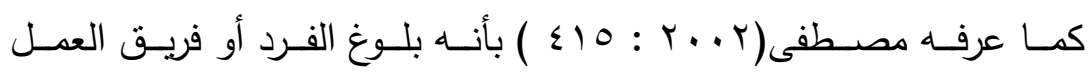

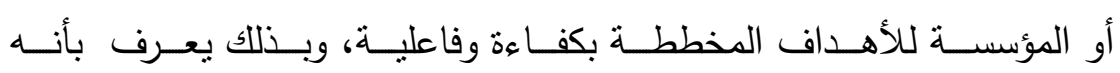

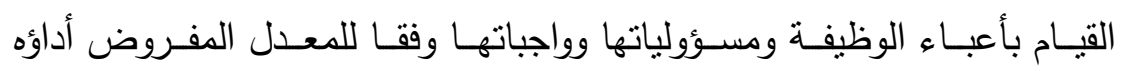
للعامل الكفء المدرب.

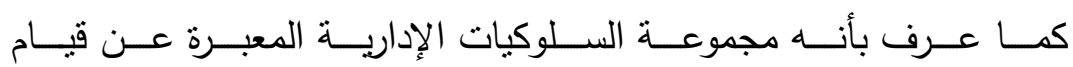

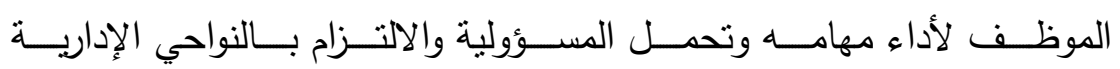

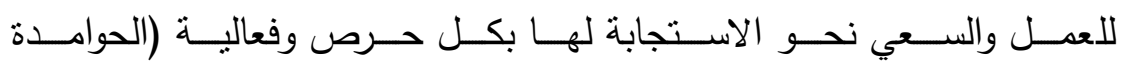

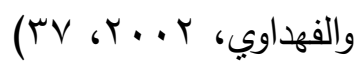

وفي هذا البحث يعني الأداء الوظيفي للعاملين : تحسين المهام المنوطة

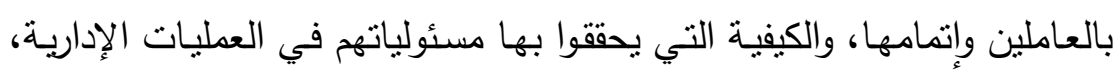

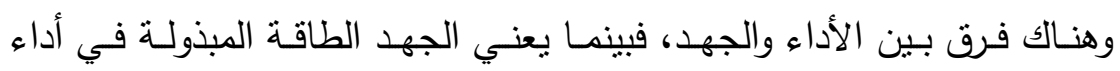

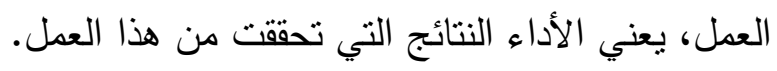
وعلى الرغم من الاختلاف بين الباحثين في تعريف الأداء الوظيفي ، إلا أن الن الني

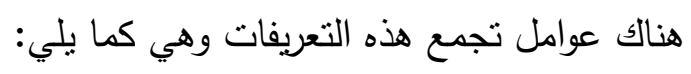

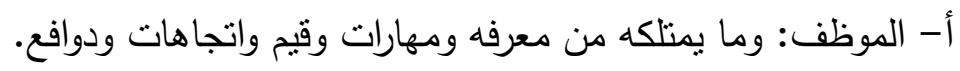

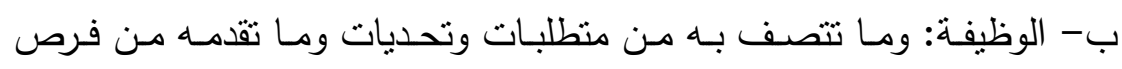
عمل. ج- الموقف: وهو مـا تتصف بـه البيئة التنظيمية والتي تتضمن منـاخ العمل

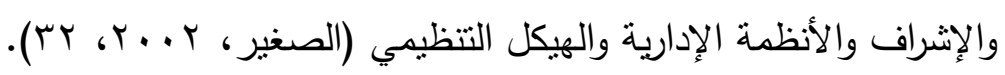


ويخلص الباحثنان إلى أن مفهوم الأداء الوظيفي هو ذلك النشاط الذي يقوم

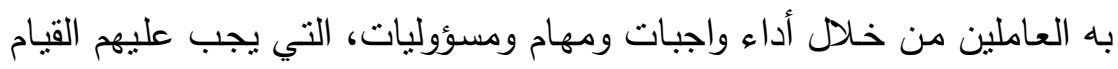

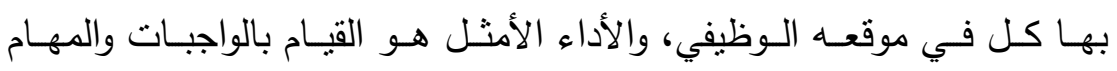

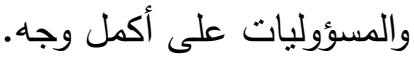

بنـاء علـى مـا سـبق نسـتطيع القـول بـأن الأداء الـوظيفي هـو قيـام الفـرد

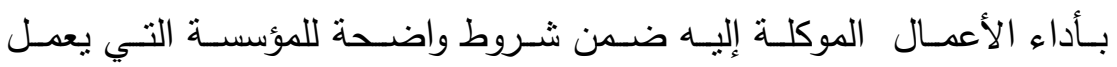

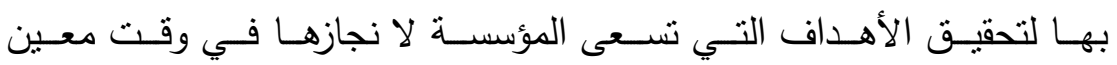
مراعيا في ذلك الكفاءة والفاعلية في العمل.

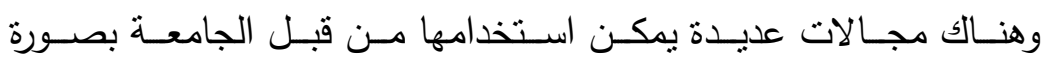

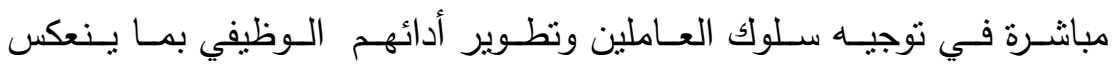
بالإيجـاب علي تحسين العمل بشـكل عـام وذلك مـن خـلال تـوفير مـا يلي:

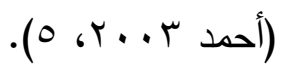

1. الاهتمام بعملية النمو المهني للعاملين بالجامعة من خلال استخدام

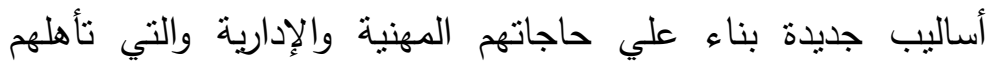
للعمل، وذلك من خلال إعطاءهم المزيد من الحرية والديمقراطية لتطبيق أفكارهم الذاتية وإظهار قدراتهم الثخصية. r. تقديم الحوافز المادية والمعنوية للعاملين بالجامعة بناء علي نشاطهم

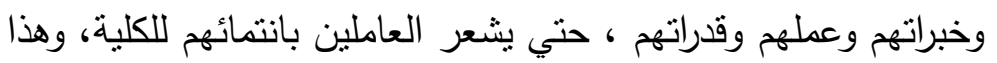
ينطلب سياسة تعليمية واضحة من قبل الإدارة توفر لهم بيئة تعليمية ومناخ تعليمي مناسب لأدائهم الوظيفي. ז. التعرف علي حاجات العاملين المهنية وتقديم دورات تدرييية أثناء الخدمة لهم بناء علي هذه الحاجات من اجل إكسابهم العديد من لنان 
المهارات التي تساعدهم في التعامل مع مكونات العمل المادية والمعنوية بسهولة ، وتسهم في تحقيق الأهداف بأقل جهد وتكلفة ووقت.

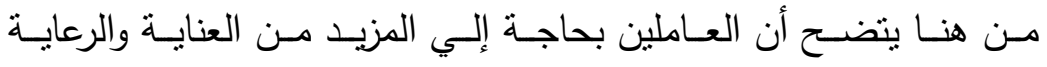

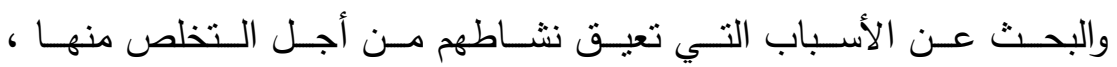

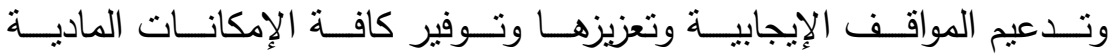

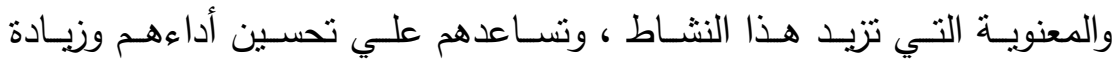

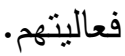
حيـث تعتبـر الحاجـة إلـى زيــادة فعاليـة العـاملين وتطـوير أدائهم مـن

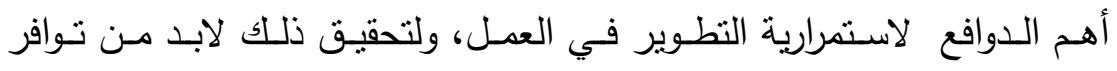

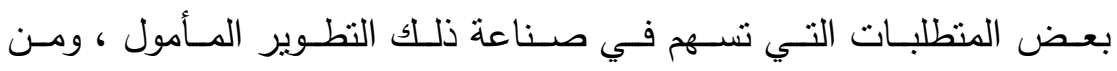

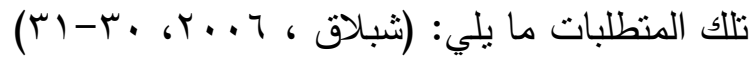
ا ب. توافر إرادة قويه للتغيير وعزيمة للنطوير أيضاً.

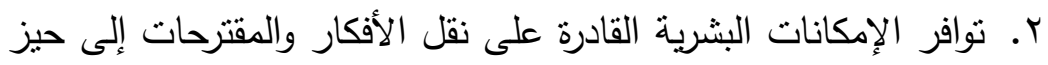
التنفيذ. r. توافر الإمكانات المادية التي تمكن من تحقيق النطوير المنشود. ـ. توافر الوقت الكافي لإجراء الدارسات وعمليات التطوير المتعددة. ه. تعزيز مشاركة العاملين في التخطيط والتتفيذ لعمليات التطوير.

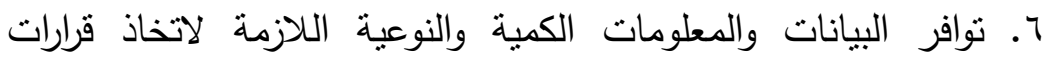

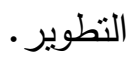

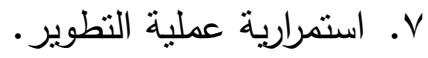
(Y) ( أهداف تطوير الأداء الوظيفي للعاملين. 
يسـعي تطــوير الأداء الـوظيفي إلـي تحقيـق التكامـل فـى في جميـع

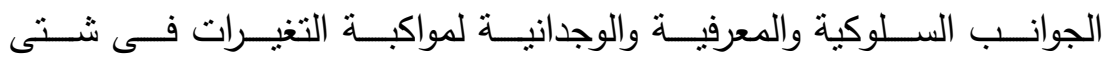

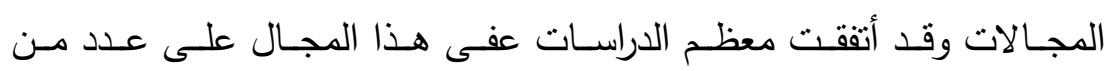

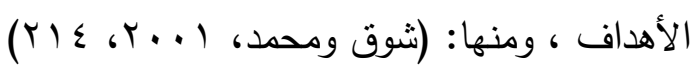

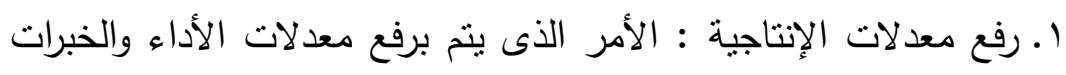
والمهارات للعاملين، ورصد القدرات والمهارات الكامنة لايهم.

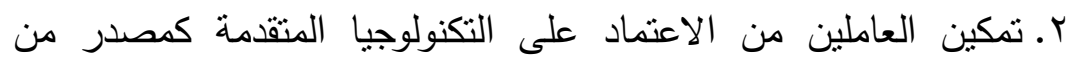
مصادر المعرفة. - مان.

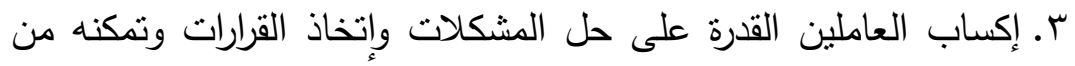
إستخدام أساليب التقويم الذاتى والتفكير الناقد والإبتكارى. ع. تتمية الإتجاهات الإيجابية لدى العاملين ، والتى من ضمنها الولاء

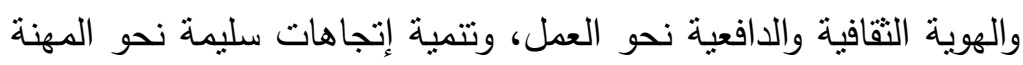

$$
\text { وأثارها الإجتماعية. }
$$

0. توسيع نظرة العاملين نحو التجريب والممارسة وتقبل الرؤى الجديدة

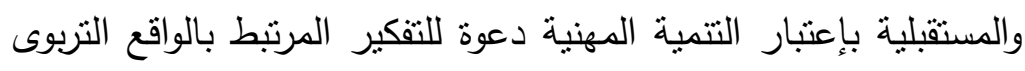
والذى يبدأ من الإحتياجات الفعلية مما يعود بالفائدة على بيئة التعليم ككل.

7 7. تجديد معلومات ومعارف العاملين لكى تتواكب مع الثورات المعرفية النى يشهدها العالم اليوم فى شتى ميادين العلم والمعرفة. v. خلق المناخ المناسب لتبادل الخبرات وتعزيز التعاون والثنقة وروح الجماعة فيما بينهم. (ץ): العوامل المؤثرة في الأداء الوظيفي : 
يتطلب تحديد مستوى الأداء الفردي معرفة العوامل التي تحدد هذا المستوى

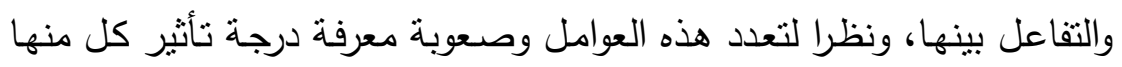

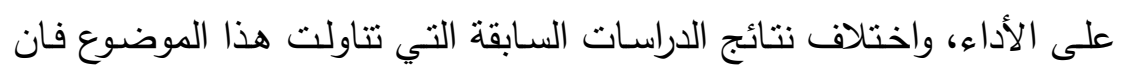

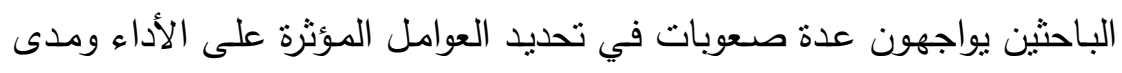
التفاعل بينها.

وهناك العديد من العوامل التي تؤثر في الأداء الوظيفي لعل من أهمها

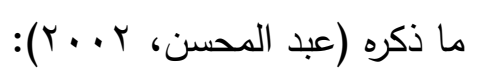

أولا: الاختلاف في حجم العمل فالمؤسسة التي تعالج حجما كبيرا في العمل

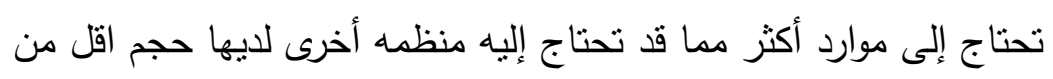
العمل نفسه.

ثانيا: التحسينات التنظيمية والإجرائية: فمعدل الإنتاج يتوقف على عوامل

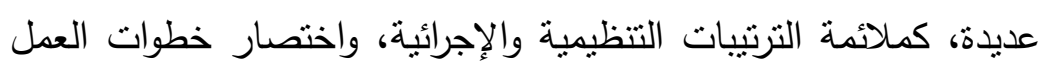
في عملية ما، يقلل من الموارد المطلوبة لإنهاء وحدة العمل.

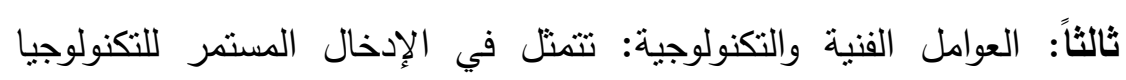
المتقدمة والحديثة من أجهزة وبرمجيات، حيث أن أداء الموظفين بتحدد

بمستوى ونوعية التكنولوجيا المتوفرة لديهم.

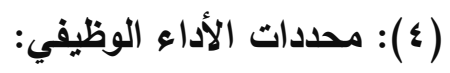

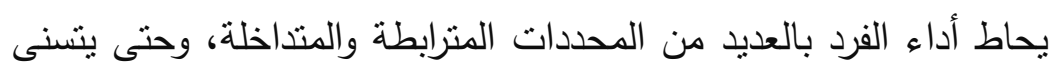

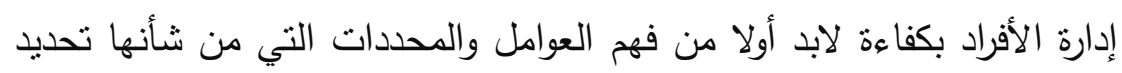
طبيعة السلوك الذي سيسلكه الفرد عند أدائه لمهام وظيفته، وقد سعى الباحثن التهن

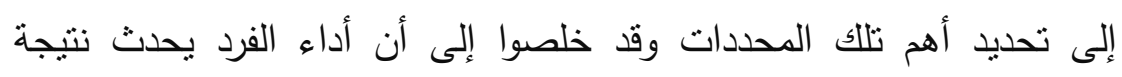

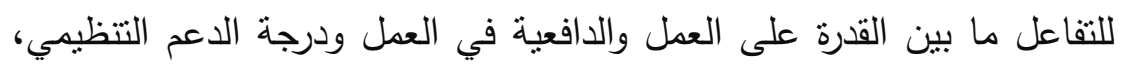

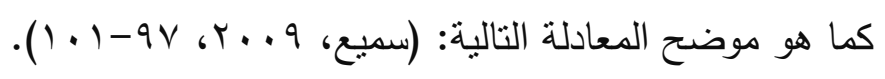




$$
\text { أداء الفرد = الدافعية+ القدرة + الدعم التتظيمي+ الإدراك. }
$$

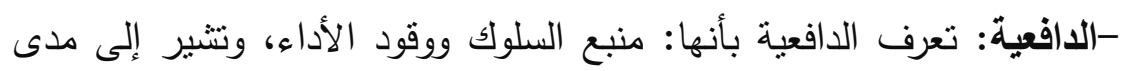

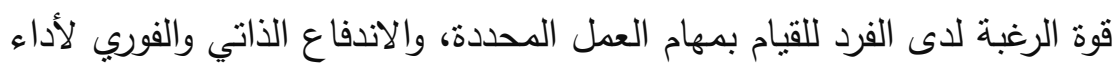

$$
\text { هذه المهام. }
$$

- القدرات: القدرات عبارة عن الخصائص الثخصية التي يستخدها الفرد

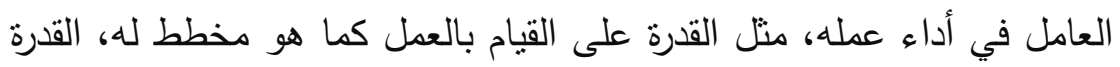

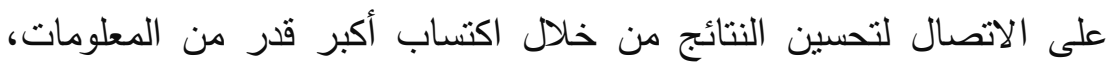

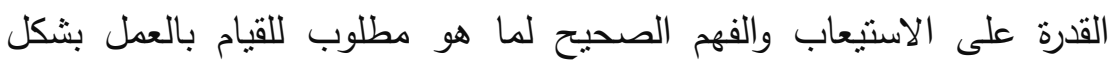

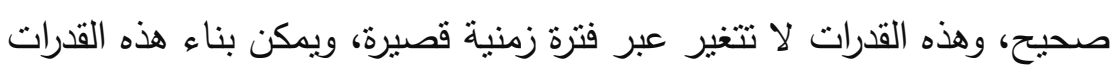

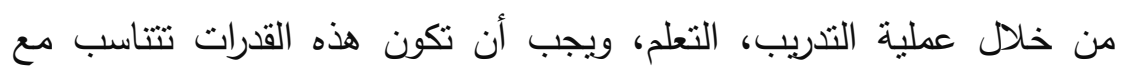
الوظيفة التي يتم أداؤها. - الدعم التنظيمي: يثير الدعم التنظيمي إلى القدر الذي تهتم فيه الدنظمة

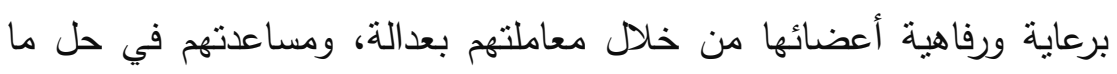
يواجهونه من مشكلات والإنصات لثكواهم. وبمعنى آخر فالدعم التتظيمي

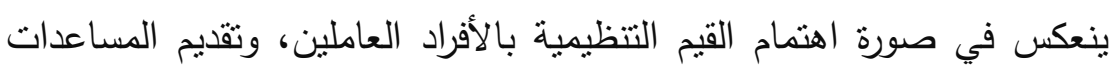

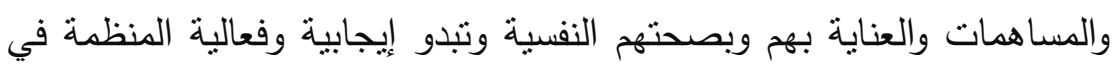
استمرارية العناية والاهتمام، مما ينعكس في صورة إدراك الأفراد لهذا التأييد

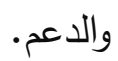

-الإدراك: بثير الإدراك إلى: "العملية المعرفية الأساسية الخاصة بتنظيم المعلومات أو أنه عملية استقبال المؤثرات الخارجية وتقسيرها من قبل الفئ الفرد الفية

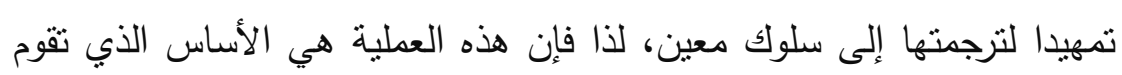

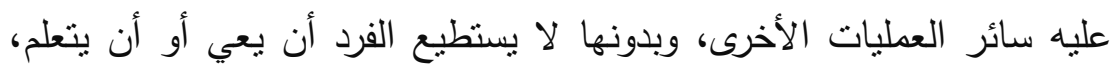


وتجدر الإثشارة إلى أن الإدراك يختلف بين الأفراد، لذا لا بد من تفهم قدرات الموظفين وأسلوب تتظيمها للمعلومات الواردة إليها.

ثانياً: الأسس القلسفية للثقة التنظيمية :

(1) (1) : مفهوم الثقة التنظيمية:

حاز موضوع الثقة التنظيمية على اهتمام الكثير من الكتاب والباحثين خاصة فى دراسة السلوك التنظيمى، وذلك لدورها الهام فى تشكيل وبناء البيئة التتظيمية الداعمة لنمو وتطور المؤسسة، فلا يوجد اتفاق حول تعريف شامل

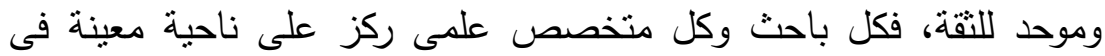

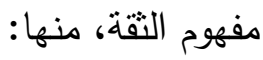
- الثقة عبارة عن توقعات ايجابية نحو سياسات وممارسات المؤسسة،

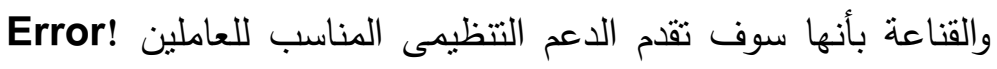
،(sonerpolat,2013:106)Unknown switch argument. ووبذللك فهى الاعتقاد القوى بأن المؤسسة تتبع إجراءات وسياسات نزيهة وواضحة وموثوق بها، وان هناك تقة وقناعة فى أهدافها وقيمها ورسالتها وتوجهاتها. كما تعد الثقة فى علاقات العمل أحد الدعائم الاساسية التى تناعد الجامعة

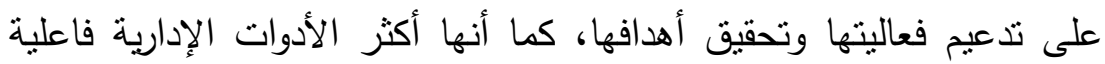

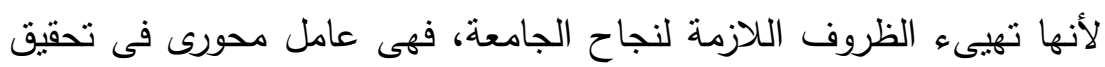

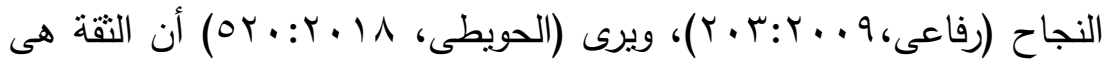

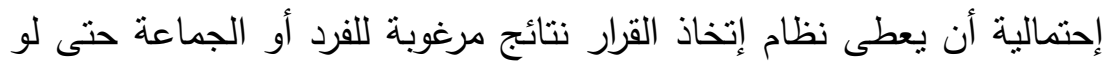
لم تتم ممارسة أى تأثير على هذا النظام، وهذا يدل على أن الوعد والإتفاق

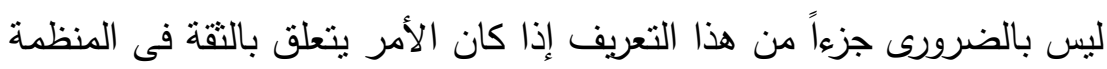


اذ يمكن الحصول على نتائج مرغوبة دون ممارسة أى تأثير على نظام اتخاذ

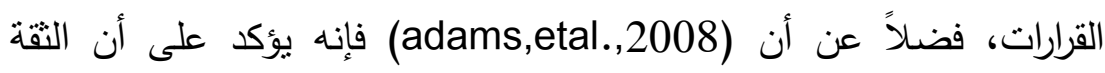
عبارة عن التوقع الإيجابى للفرد أو الجماعة عن السلوك الأخلاقى للآخرين والذى يتمثل فى قراراتهم وتصرفاتهم.

وبناء على ما سبق ترى الباحثتان أن النقة التنظيمية هى توقعات

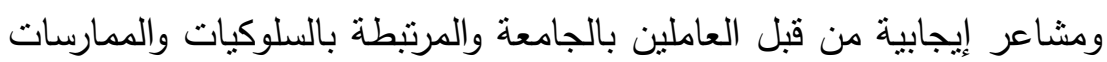

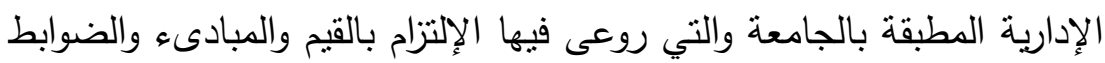
الاخلاقية السليمة، مما ينتج عنه إيمان العاملين بأهدافها وسياساتها وقراراتها ورغبته فى الاستجابة للتعليمات والقرارات ومدى قناعته بسلامتها ومنطقيتها،

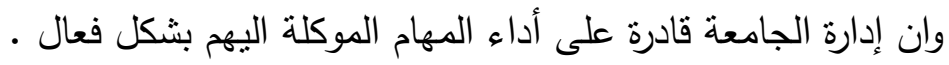

\section{(Y) ( أهمية الثقة التنظيمية}

يعتبر تكوين الثقة شرطا أساسياً لضمان التفاعل والتبادل المشترك بين

العاملين، لإنجاز المهام والفعاليات المختلفة بالجامعة لما يسهم فى نجاحها

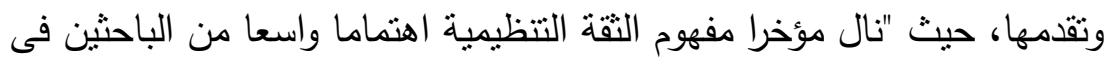

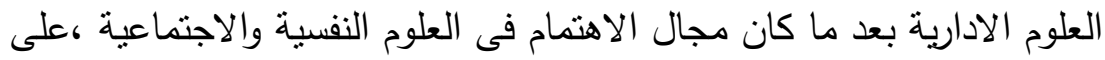

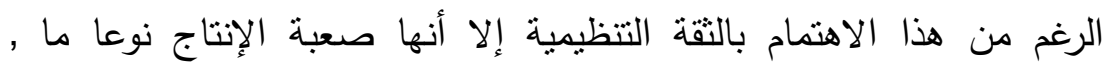

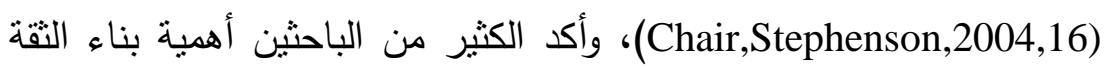
التتظيمية فى المؤسسات بين الأطراف المعنية؛ إذ أن بناءها بيتغرق وإنتاً

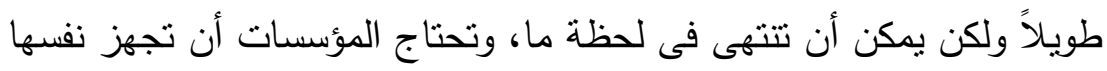
ليس فقط لكسب الثقة بل للحفاظ على هذه النقة (boe,2002:4). بالإضافة إلى أن المنظمات التى تسود أعمالها وأنشطتها وعلاقاتها

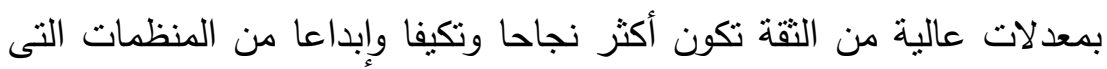


تتعدم بها الثقة، والتواصل بين الأفراد، وإرتفاع الروح المعنوية فيما بينهم، وتقبل

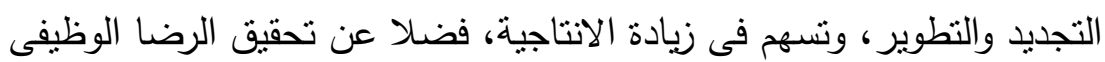

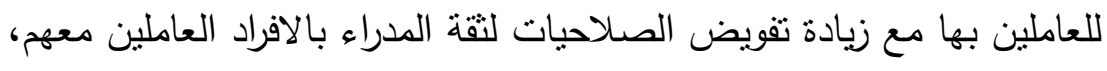

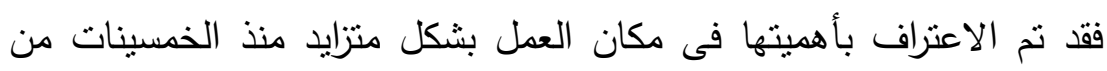

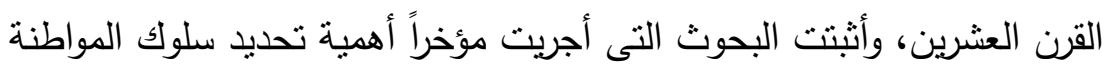

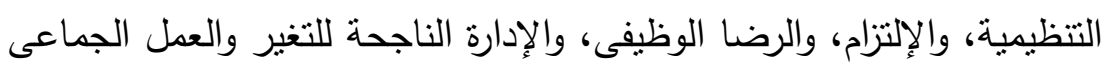

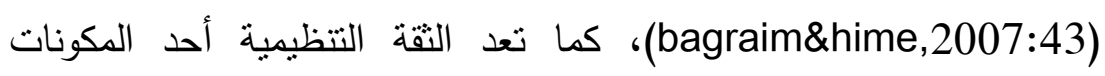

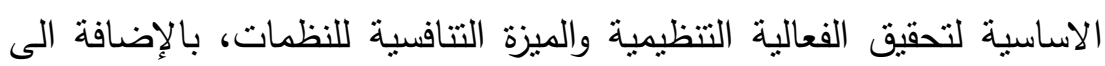
أهميتها فى زيادة فرص النجاح والنمو النتظيمى وزيادة الالتزام وسلوكيات المواطنة التنظيمية (رضوان، ع ( • ب: (1)).

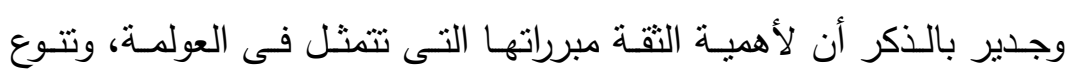

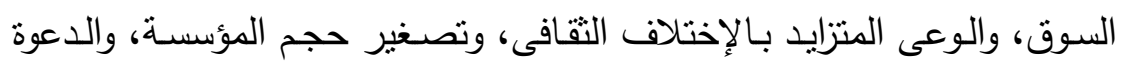

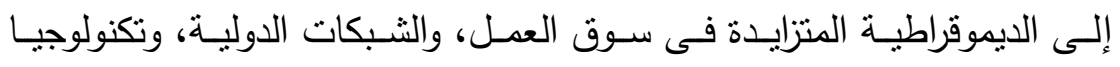

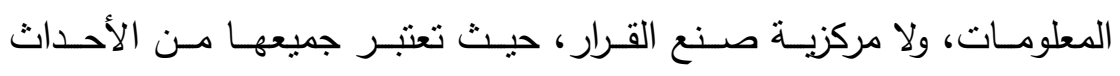

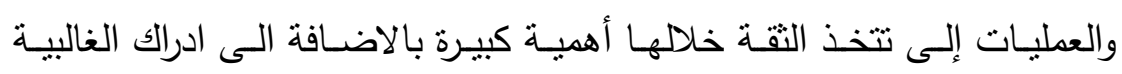

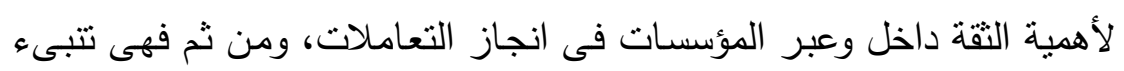

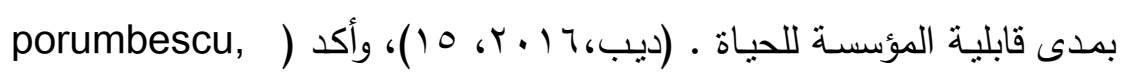

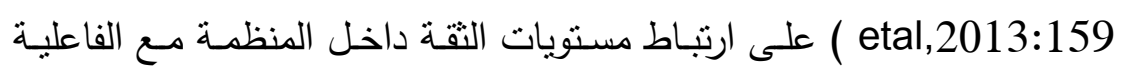
ومستويات الأداء التنظيمى، هناك مجموعة كبيرة من البحوث تتعلق بالقطاعين

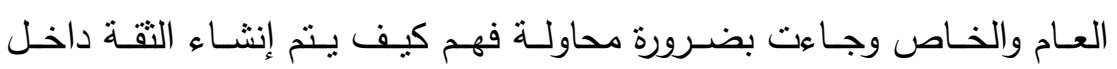
المنظمات وذلك من خلال توفير أفضل الظروف التى نساعد على ظهور التقة التنظيمية . 
مما سبق ترى الباحثتان أن النقة التظيمية تزيد من تبادل الافكار بين

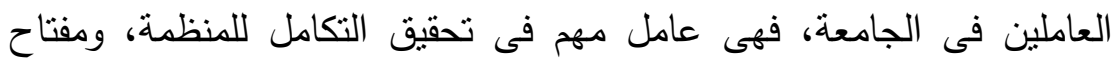

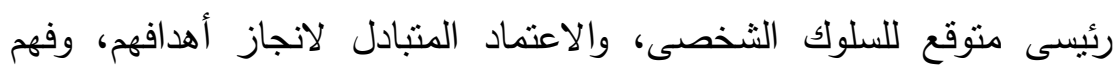

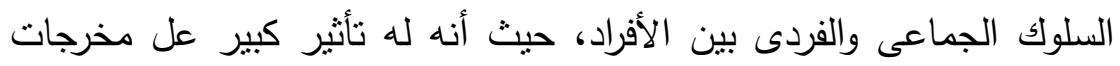

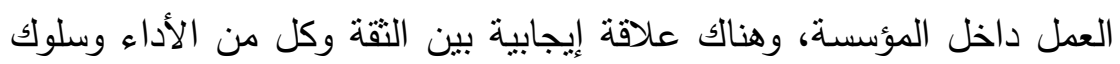
المواطنة والإبداع. وفي ضوء ما تقدم وحتى تتحقق الثقة لدى العاملين، فلا بد من الندول من

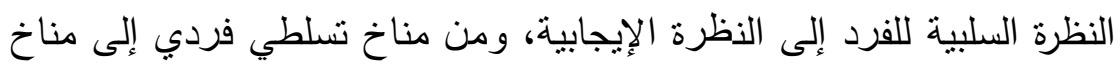
تشاركي جماعي، يتيح فرصة للفرد التعبير عن آرائه وأفكاره وتوليد الثنعور لديه بالعدالة والثقة في تحقيق أهدافه. فنشعور الفرد بثقته وإنتمائه لمؤسسته

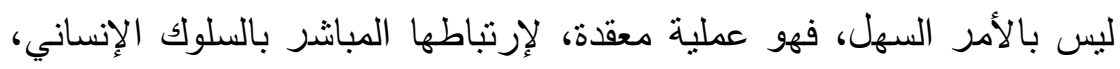

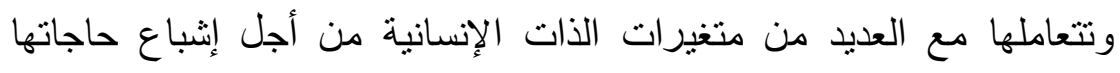
المرتبطة بالظروف الداخلية والخارجية للفرد.

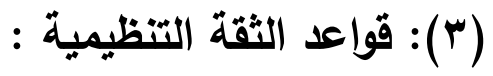

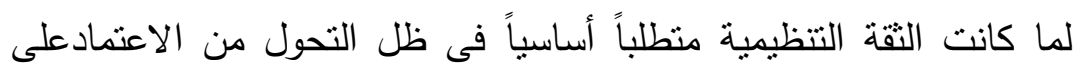

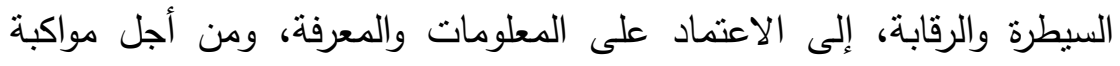

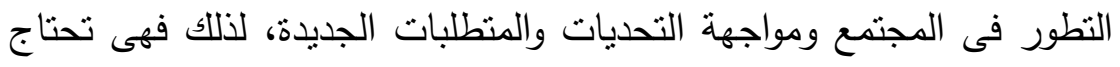

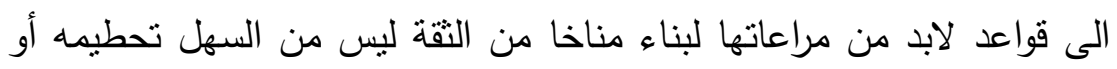

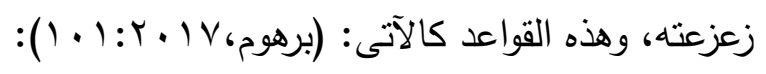

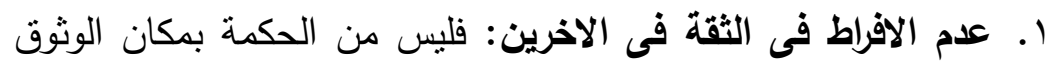

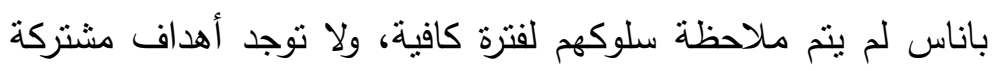


r. محدودية الثقة: ثقة بلا حدود تعنى ثقة غير واقعية، حيث أن الثقة بحدود فى المنظمات نعنى الثقة بقدة العاملين والتزامهم بتحقيق الاهداف والتضحية من أجل تحقيقها. r. القدرة على التعلم والتكيف: إذا كان البناء التنظيمى يحدد مدى ملى استقلالية وثنات الجماعات، فان بعض الظروف قادرة عل إحداث تغيير، لذا يتوجب على المنظمات امتلاك القدرة على التكيف. ء. الحزم: تتطلب الثقة الحزم، لذا يتوجب على الإدارة إختبار موظفين

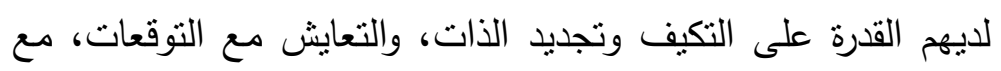
إمكانية الاعتماد عليهم فى إنجاز المطلوب.

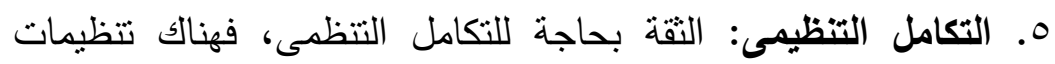

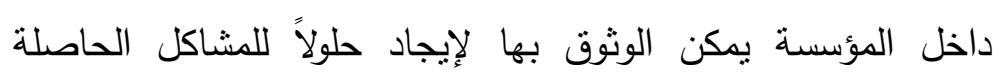
بالمؤسسة.

7. الاتصال: حاجة الثقة للتصال يتطلب اتصالاً شخصياً لكى يكون

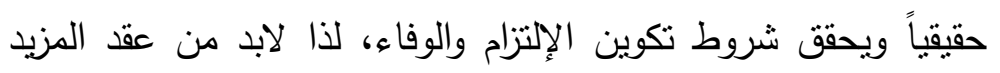

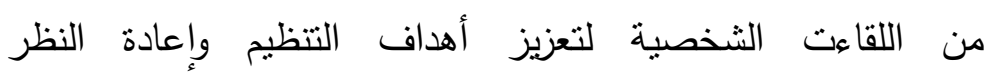
بالاستراتيجيات التتظيمية.

V. تعددية القادة: نتطلب الثقة تعددية فى القادة حيث أنه من الصعوبة

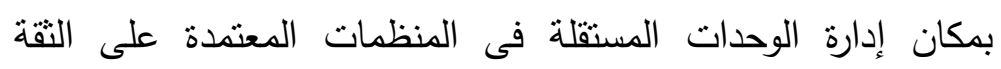
وحدها.

^. تناقض الثقة التظيمية: من السهل تحطيم التقة إذا ما ذهبنا بطرق

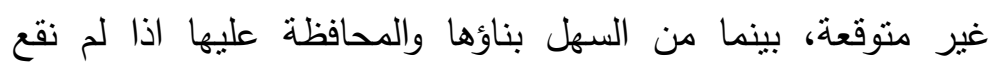
ضحايا للتفكير السطحى الضيق. 


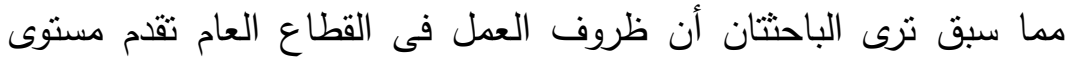

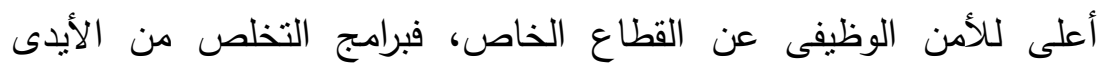

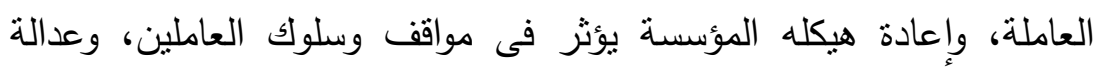

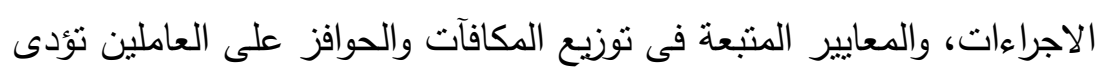

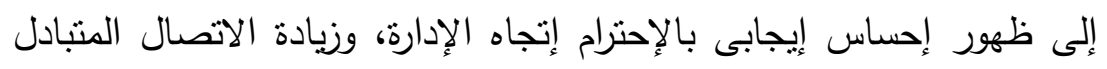

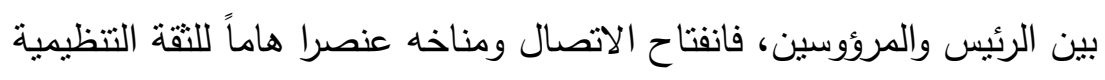

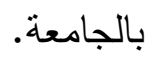

\section{( ) : أنواع الثقة التظيمية :}

النقافة التنظيمية من الممكن أن تكون ضعيفةً أو قويّةً؛ وذلك من خلال

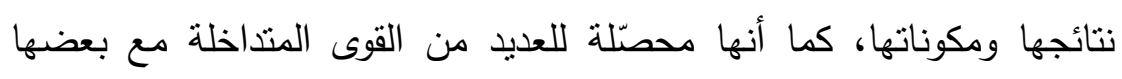
البعض في حال كانت هذه القوى تفيد أو تُاسب مصلحة العاملين بالجامعة،

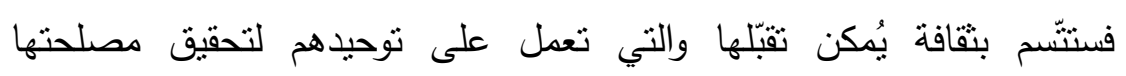

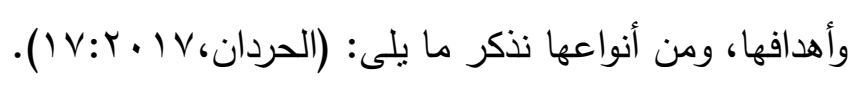

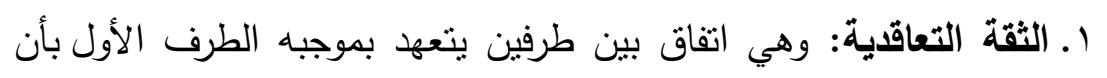

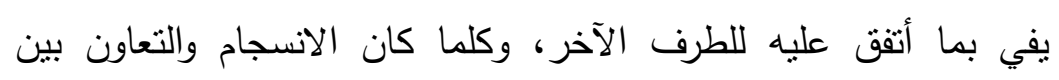

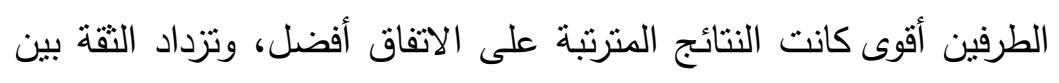
الطرفين من خلال الالتزام بالتعهدات.

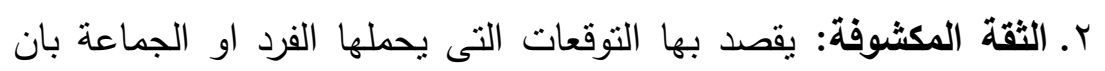

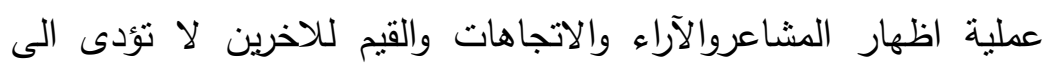

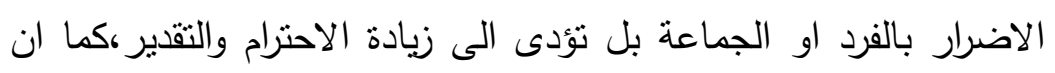

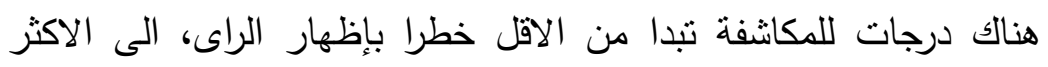
خطورة فى المشاركة الوجدانية والمشكلات الشخصية. 
r. الثقة المبنية على العاطفة: وهي ناجمة عن الارتباطات العاطفية بين

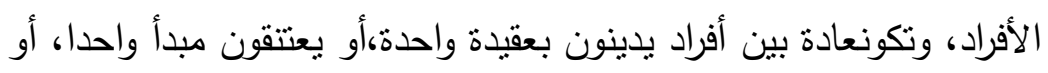

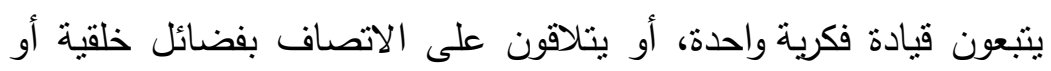
توجهات سلوكية معينة.

ع. الثقة المبنية على المعرفة؛ وهى الثقة فى المعتقات الفئة الفردية حول موثوقية الزملاء ومدى امكانية الاعتماد عليهم،وتكون التقة مستتدة الى المعرفة عندما نختار من نثق به فى جوانب وظروف محددة وعندما نرجع الاختيار

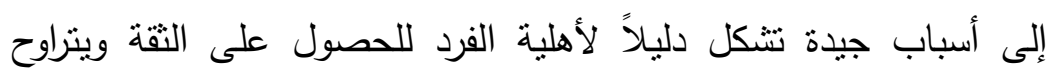

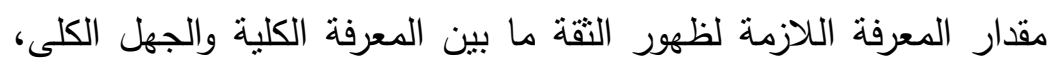
وتوفر المعرفة المتوفرة والاسباب الجيدة قاعدة لإتخاذ القرارات المتعلقة بالتقة .

\section{(0) أبعاد الثقة التظيمية وعلاقتها بتحسين الأداء الوظيفي :}

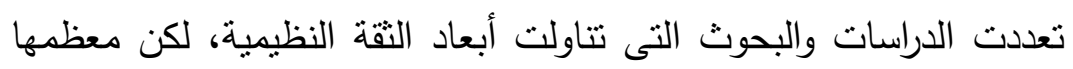

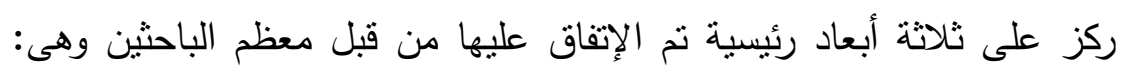

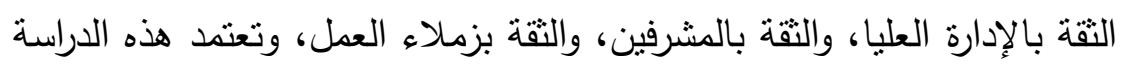

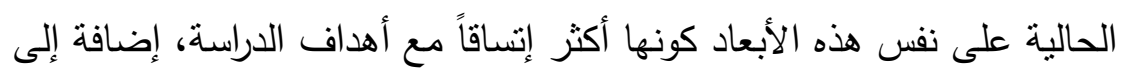

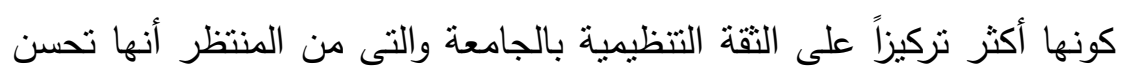

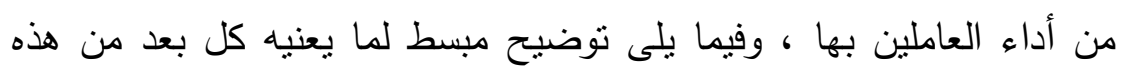
الأبعاد:

1. الثقة بالإدارة العليا: وهى تمثل نوقعات الأفراد أو الجماعات بأن

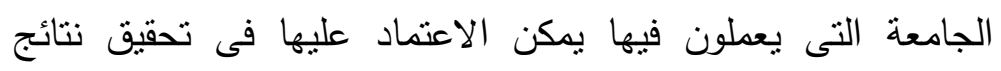

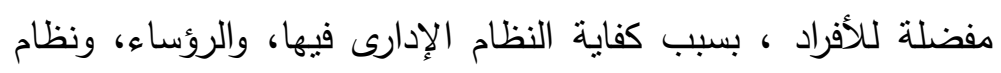

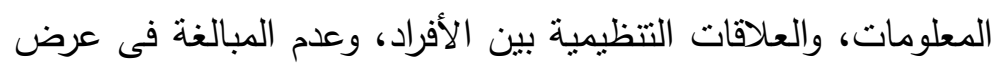
- ro 
الحقائق (الحوامدة، 9 . . ץ:V T)، والثقة سمة أساسية مرتبطة بأداء

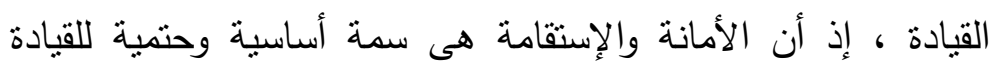

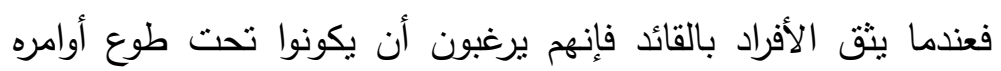

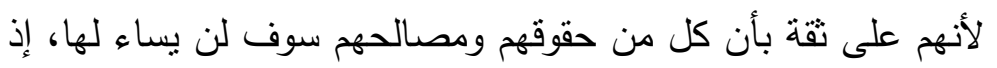

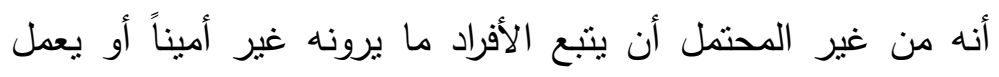
على إستغلالهم (robbin,2003:337).

وترى الباحثتان أن الثقة بالإدارة العليا تثير إلى تقة الأفراد بقدرة الجامعة

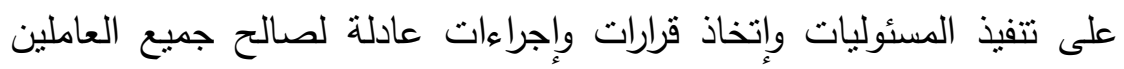
بها، وتقديم دعماً نتظيمياً ملائماً لهم، وخلق مناخاً من العلاقات واتجات الإنسانية

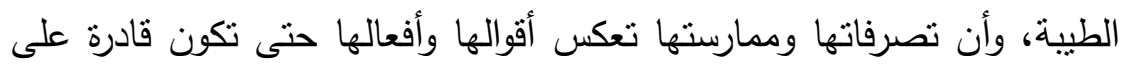
إدارة الجامعة بكفاءة وفاعلية مما يجعلها تتمتع بسمعة طيبة سواء داخل الكلية

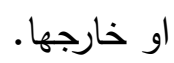

r. الثقة بالمشرفين: وهي تتبثق من تصورات الفرد ومدركاته عن المشرف

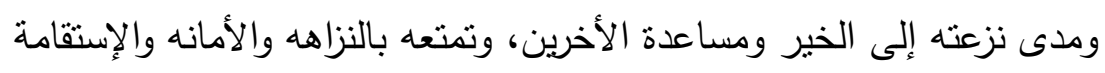

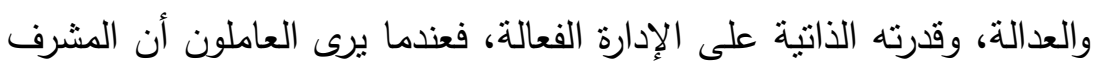
يهتم بهم وبرفاهيتهم وبمشكلاتهم، ويقدم لهم الفرص المتاحة لبساعدهم على لئل

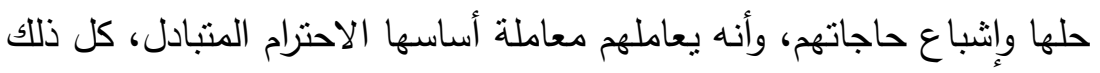

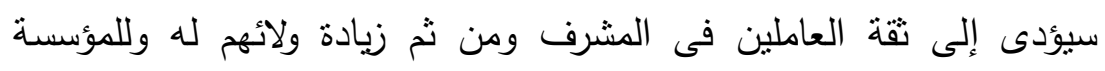
.(mourad.m,2014:23)

وأكدت إحدى الدراسات أن الثقة فى المشرف نابعة من العلاقات الثخصبة والعدالة التفاعلية وهى الطريقة التى ينم بها توصيل المعلومات المتعلقة بالمنظمة للمرؤوسين من قبل المشرف لتكوين تصورات عن العدالة التفاعلية 
porumbescu etal, ) والتى بدورها تؤثر على نقة المرؤوسين بالمشرفين

$$
\text { . } 2013 \text { : } 38
$$

وبناء على ما سبق ترى الباحثنان أن ثقة المشرفين تثير إلى ثقة الأفراد

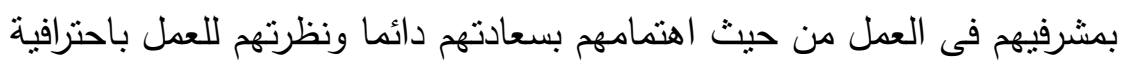

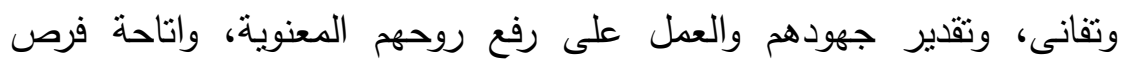

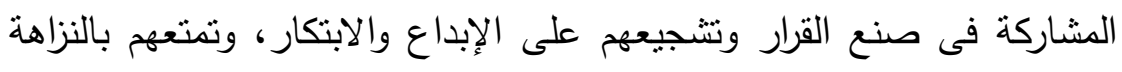
والثنفافية والموضوعية فى التعامل مع جميع العاملين.

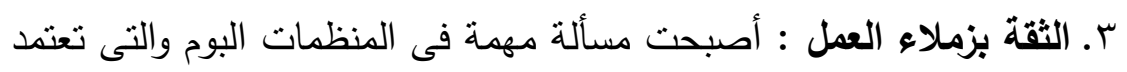
بشكل كبير على مجموعات او فرق العمل، الذين يتمتعون بمهارات تكاملية،

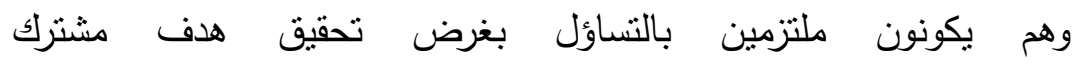

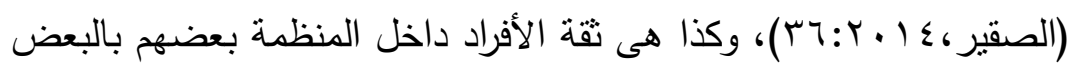
الاخر من خلال العلاقات التعاونية والانسانية الطيية، والاتصالات المفتوحة الإنة والاعتماد المتبادل بين الجميع، وانتراكهم فى المشاعر والاهداف والافكار

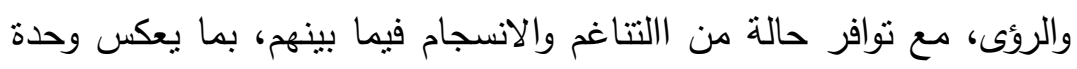

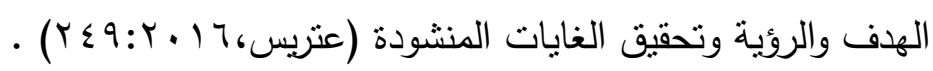

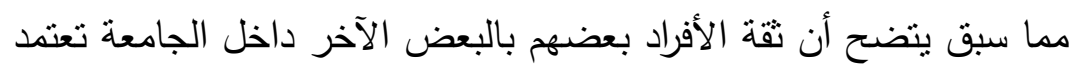

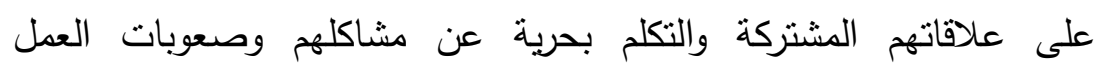
وانشتراكهم فى المشاعر والآمال، وذللك بما يسهم فى تحقيق الاهداف والغايات

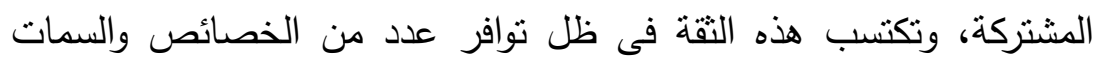
التى تجعل الفرد جديرا بثقة الاخرين وتشمل كل من الالتزام فى العمل والقيم

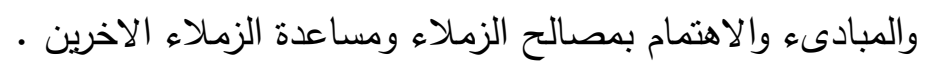


بالإضافة الى ما أكده كلا من (kort\&lewicka,2012:224) أن أبعاد التقة ثلاثة: التقة العمودية أو الرأسية وتكون بين المديرين والعاملين، والتقة

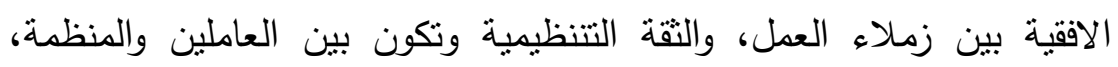

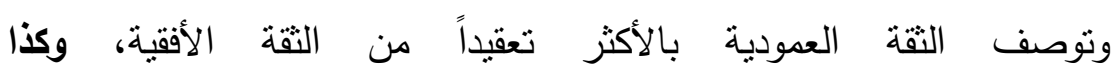

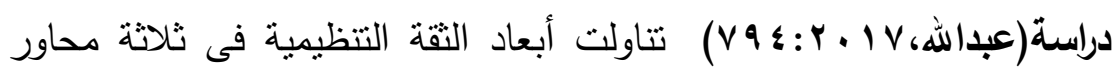

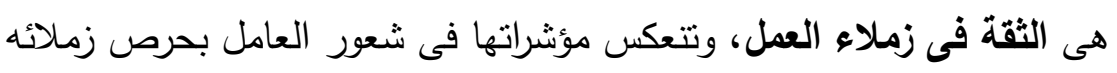

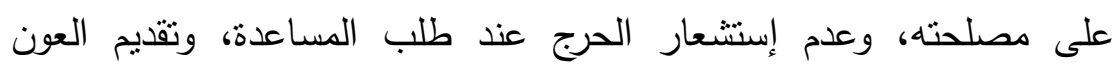
للزملاء، والثقة المنبادلة، وتبادل المعلومات فيما بينهم، والثثة فى الرئيس

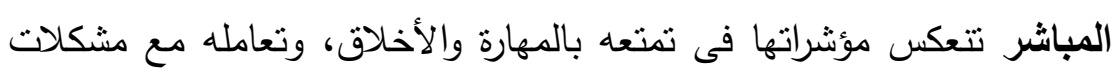

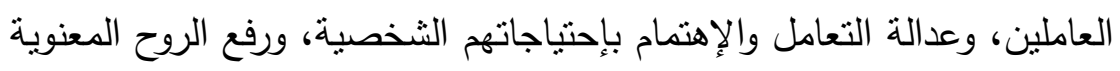

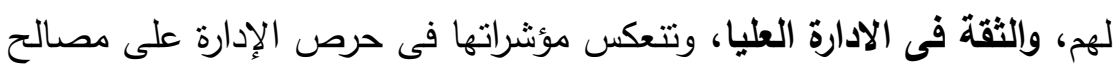

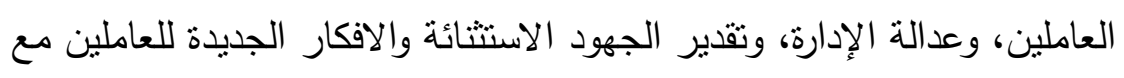

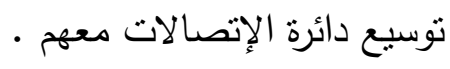
( آ) العوامل المؤئرة فى الثقة التنظيمية :

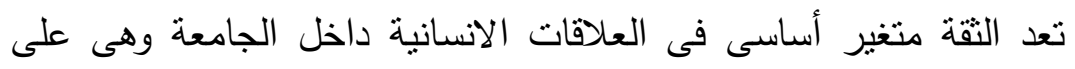

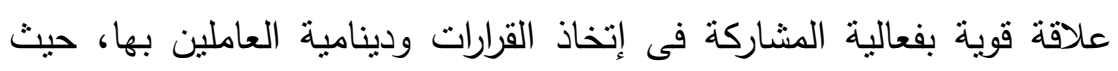

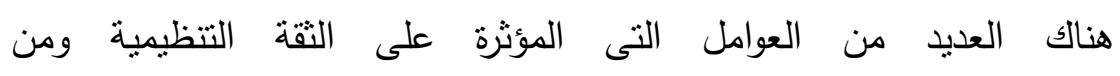

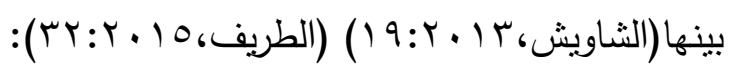

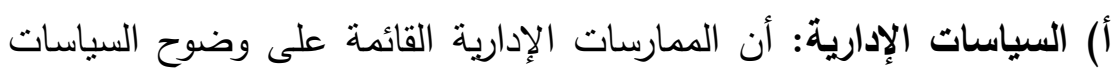

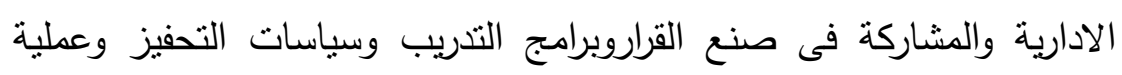

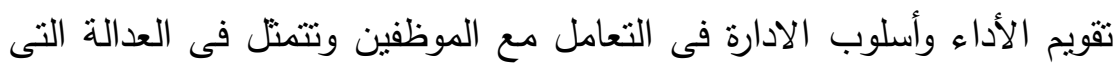

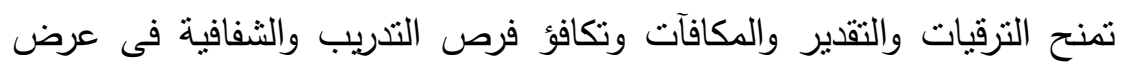
الحقائق والتعامل الجيد بين أفراد المؤسسة. 
ب) الإبتكار وتحقيق الأات: المقصود هنا أن الإدارة تثق فى قدرات مرؤوسيها وتقدر مجهوداتهم وتقوضهم ببعض الصلاحيالت وتتجعهم على الإبتكار والتجديد فى بيئة العمل وتعمل على تتفيذ بعض مقترحاتهم وتعززها لديهم .

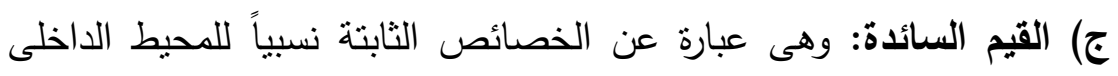

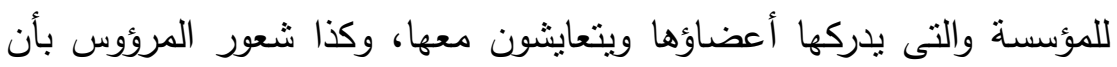
لايه إدارة متمثلة فى شخص القائد التربوى تحمل سمات التدين والإلتزام

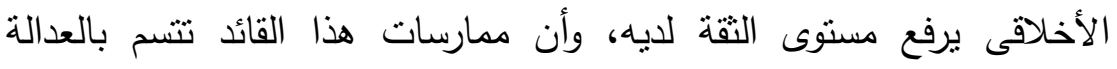
والموضوعية قراراته واجتهاداته فى تحرى الدقة وإبراء الذمة. د) المعلومات المتاحة في التظيم: يتضمن ذلك توافر المعلومات الثاملة الدقيقة المؤسسة للموظف فى الوقت المناسب، بما يضمن مصداقية مصادر المعلومات التى يتعامل معها فى بناء أجواء من النقة التتظيمية، وتعزيز قدرة

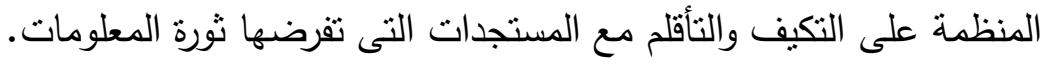
مما سبق ترى الباحثان أن هناك عوامل رئيسية نولد الثقة التتظيمية منها

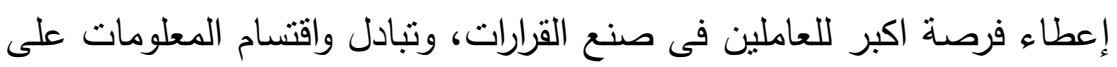

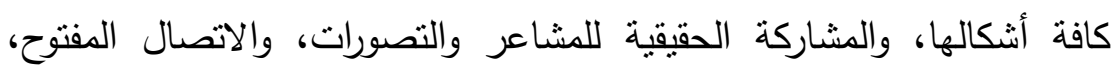
والسعى نحو إنجاز الأعمال بدقة، وإظهار الإهتمام بالمرؤوسين فيما يتصل بالخدمات والمعاملات، ومتابعة ظروفهم ومشكلاتهم الخاصة، توفير البيئة الاعنة

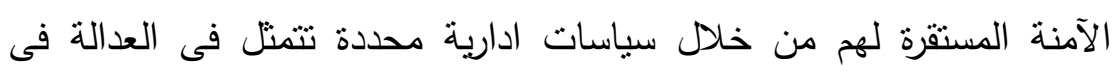
الترقية، وتطبيق النظام على الجميع، سيادة العلاقات الجيدة بين العاملين في المنظمة ووجود إحترام لقيمة الوقت لدى العاملين بالجامعة. 


\section{الإطار الميداني}

- الهـدف مـن الدراسـة الميدانيـة: دراسـة واقع دور التقـة التتظيميـة في الأداء

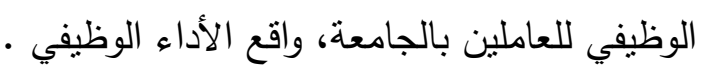
- مجتمع البحث لمن

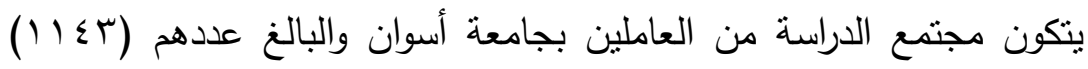

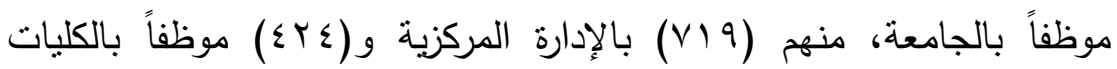
المختلفة.

\section{- وصف العينة}

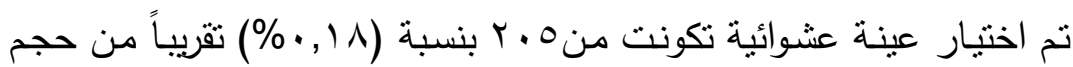
العينة الكلي (العاملين بجامعة أسوان). - أداة البحث: ألمينة تم تصميم استبانة لتحقيق أهداف البحث، حيث تكونت الاستبانة في صورتها الأولية محورين : المحور الأول ويتعلق بواقع أداء المعلمين بالجامعة ويتكون

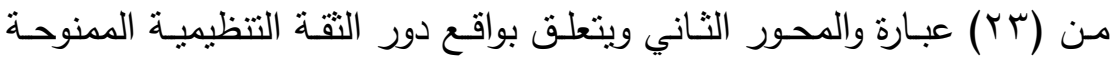

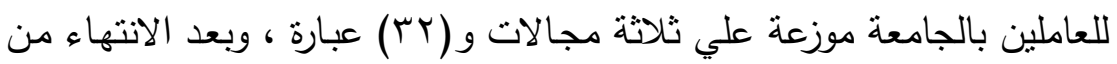


بنـاء الصـورة الأوليـة للاستبانة تم عرضـها على مجموعـة مـن أعضـاء هيئة

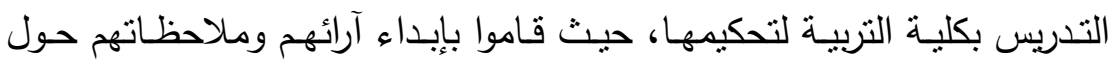
مناسبة عبارات الاستبانة، ومدى انتماء العبارات إلى مجالات الاستبانة، وكذللك

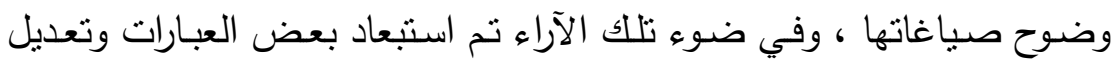
بعضها الآخر ، كما في الجدول التالي:

جدول (1)

التعديلات التي أجريت علي عبارات الاستبانة

\begin{tabular}{|c|c|c|c|c|}
\hline \multirow[b]{2}{*}{ عدد العبارات المعدلة والمحذوفة } & \multicolumn{2}{|c|}{ العدد } & \multirow[b]{2}{*}{ المجال } & \multirow[b]{2}{*}{ المحور } \\
\hline & بعد التحكيم & قبل التحكيم & & \\
\hline تم حذف العبارات (r، ع (، بr) & r. & r & & الأول \\
\hline تم تعديل العبارة رقم (ॅ)، (^) & 1. & 1. & الأول & \\
\hline تم حذف العبارتين( ؛، V) . & 1. & ir & الثانى & \\
\hline 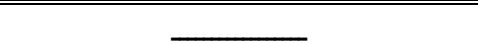 & 1. & 1. & الثالث & الثانى \\
\hline تم حذف (0) عبارات، وتعديل عبارتين & o. & 00 & & اله \\
\hline
\end{tabular}

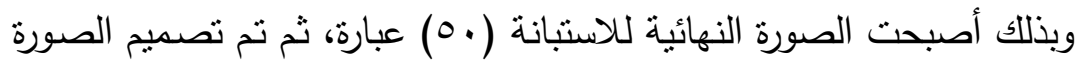

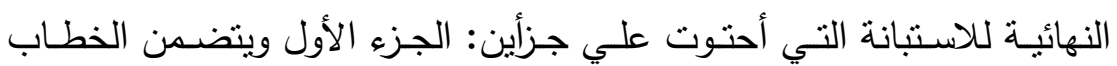
الموجه إلي عينة الدراسة والجزء الثاني يتضمن مجانهات الات الاستبانة.

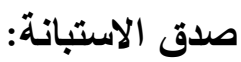

- صدق المحكمين : نم التأكد من صدق الاستبانة وصلاحيتها للنطبيق، وذلك

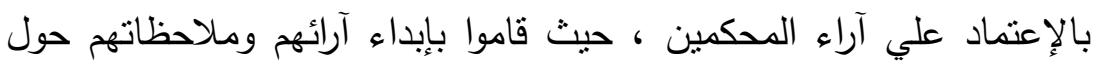


مناسبة عبارات الاستبانة ووضوح صياغتها اللغوية، وفي ضوء تللك الآراء نم إستبعاد بعض العبارات وتعديل البعض.

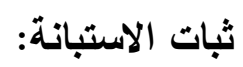

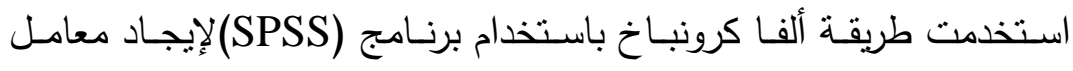

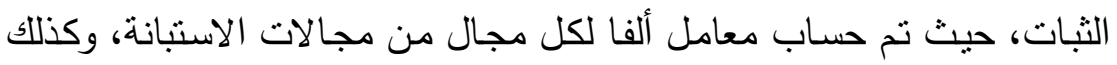

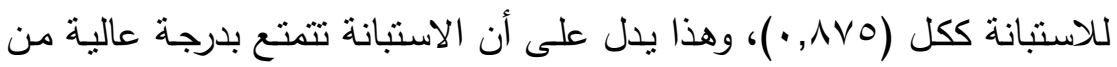

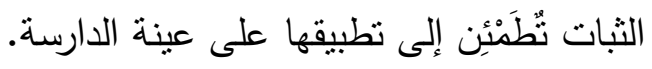

الأساليب الإحصائية المستخدمة في الاراسة: تم استخدام البرنامج الإحصائي (SPSS)، حيث استخدم فئلائه عددا من الاساليب الإحصائية المناسبة لطبيعة البحث، وهي : - - التكرارت والنسب المئوية. - المتوسط الحسابي. - - الانحراف المعياري لكل فقرة من فقرات كل مجال، وكذللك ترتيبها. ولتسهيل تفسير النتائج استخدم الأسلوب التالي لتحديد مستوي الإجابـة علي

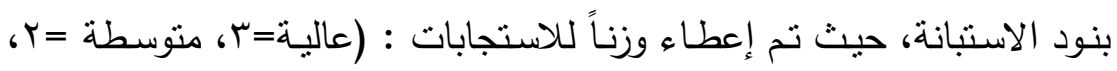

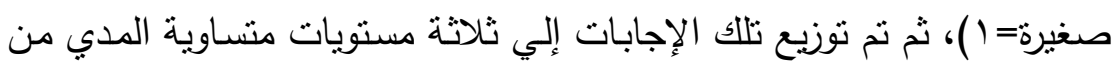
خلال المعادلة التالية : بالية

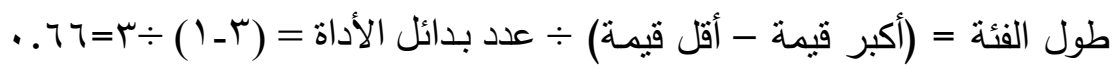

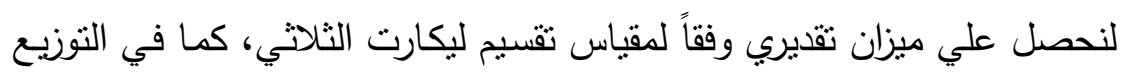

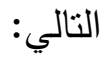
جدول (r) ميزان تقديري وفقاً لمقياس تقسيم ليكارت الثلاثي 


\begin{tabular}{|c|c|c|}
\hline الاتجاه العام & المتوسط الحرج & الاستجابة \\
\hline عالٍ & من ع ז.rإلي r & يتحقق بدرجة عالية \\
\hline متوسط & من VI. إلي س. & يتحقق بدرجة متوسطة \\
\hline ضعيف & من ا إلي 7.1. & بتحقق بدرجة صغيرة \\
\hline
\end{tabular}

\section{مناقشة النتائج وتفسيرها:}

للإجابة عن السؤال الثالث ما واقع الأداء الوظيفي وواقع دور الثقة التظيمية في

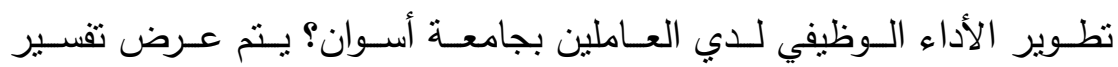

$$
\text { لاستجابات أفراد العينة ، وذللك كما يلي: }
$$

أولاً: النتائج المتعلقة بواقع الأداء الوظيفى للعاملين بجامعة أسوان :

$$
\text { جدول (r) }
$$

\begin{tabular}{|c|c|c|c|c|c|c|c|}
\hline \multirow{3}{*}{ الإستاه } & \multirow[t]{3}{*}{$ت$} & \multirow{3}{*}{ المتو } & \multicolumn{3}{|c|}{ يتحقق بدرجة } & \multirow[b]{3}{*}{ العبـــــــــــارة } & \multirow[b]{3}{*}{5} \\
\hline & & & 15 & ك & ك & & \\
\hline & & & $\%$ & $\%$ & $\%$ & & \\
\hline متوسط & 1. & $1.9 \mathrm{~V}$ & ro. & $01 . Y Y$ & $r$ r.qr & التلازمتعة التطوير العمل. بالمهارة المهنية و والفنية & 1 \\
\hline متوسط & 11 & $1.9 r$ & Y Y.rs & 00.71 & $11 . .0$ & 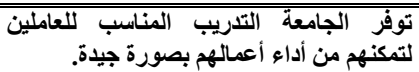 & r \\
\hline عالٍ & 0 & Y.0Y &.$\cdots$ & $\varepsilon \varepsilon . r q$ & 00.71 & يلتزم العاملون بأنظمة وقوانين العمل. & $r$ \\
\hline عالٍ & 7 & Y.00 & $\because \cdots$ & $\leq 0 . r v$ & $0 \leq .74$ & أدئراء العمل. العاملون أوامر رؤسنائهم تحقيقاً لجودة & $\varepsilon$ \\
\hline ضعيف & 11 & $1 . r$. & $\vee 9.01$ & $r . . \leq q$ & $\because \cdots$ & تتناسب رواتب العاملون مع حجم مهامهم. & 0 \\
\hline ضعيف & IV & $1 .<9$ & $0 . . V T$ & $\leq 9 . r V$ & $\because \cdots$ & فيته عملهم. العاملون من أى مسئووليات إضافية & 7 \\
\hline متوسط & 9 & $r . \cdot 1$ & Y.TE & rq. r & $r \leq .7 T$ & طارئة في العملين على التكيف عند حدوث حالات & V \\
\hline متوسط & Ir & 1.9. & Y.TE & ov. V V & 17.09 & يتم تقديميم الأداء الوظيفى للامعلين وفقا لمعايير & $\wedge$ \\
\hline متوسط & $1 \%$ & $1 . \wedge 1$ & $r 0.71$ & $\leq \vee . \wedge$. & 17.09 & يغطى العاملون على اخطاء زملائهم فى العمل. & 9 \\
\hline عالٍ & 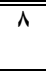 & $r . \leqslant 7$ & 1.90 & $\leqslant 9 . \vee 4$ & $\leqslant \Lambda . Y q$ & يؤدى العاملون واجباتهم الوظيفية بلةقة & 1. \\
\hline متوسط & $1 \leq$ & 1.71 & $\Delta V_{.} \cdot v$ & $11 . .0$ & $Y \leq . \wedge \wedge$ & إنجاز العمل. معظ العاملون بمساعدة رؤسائهم فى & 11 \\
\hline
\end{tabular}

استجابات أفراد العينة علي المحور الأول 


\begin{tabular}{|c|c|c|c|c|c|c|c|}
\hline عالٍ & $\bar{r}$ & Y.71 & $\therefore$ & $r q . r^{2}$ & 7.91 & اليبذل العاملون. الجها الكافى لانجاز الاعمال فى & Ir \\
\hline عالٍ & 1 & r.v. & $\therefore$ & $r ., Y \leq$ & 79.17 & مئتزم المسئول المباثُون بتليمات وتوجيهات الصادرة & $1 T$ \\
\hline عالٍ & 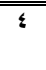 & r.09 & 1.90 & $r v . \cdot v$ & $7 . .91$ & أنجازقها. العاملون بالجامعة الاهداف المطلوب & $1 \leqslant$ \\
\hline عالٍ & $\overline{T r}$ & r.Tr & $\therefore$ & r..०9 & Tז\& & 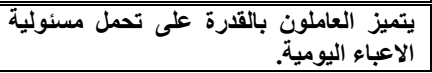 & 10 \\
\hline ضعيف & 17 & $1.7 \mathrm{r}$ & $0 \wedge .0 \leqslant$ & $r \cdot . \leqslant q$ & $Y \cdot .9 \wedge$ & اثثناء ادائهم الوظيفيى. & 17 \\
\hline متوسط & $\bar{v}$ & Y.o. & Y. $\leqslant$ & ؛ $₫ . \wedge \Lambda$ & ג.ד. & المتمتويات الادارية لتحقيق جودة العمل. & IV \\
\hline ضعيف & 10 & 1.77 & $\sum V . r Y$ & $r 9.01$ & Ir.IV & 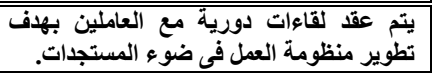 & 11 \\
\hline عالٍ & 0 & $r .07$ & $\therefore$ & 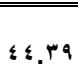 & 00.71 & تشهرص في تحسين اداء العمل. تقليم المبادرات التى & 19 \\
\hline عالٍ & $\overline{1}$ & r.v. & $\therefore$ & $r \cdot r \leq$ & 79.17 & العالملين من قبنل الرؤساء. والمتابعة المستمرة لأداء & $r$. \\
\hline
\end{tabular}

\section{من خلال الجدول السابق يتبين لنا التالى :}

- جاءتا العبارتين رقم (ب(، • Y)، والتى تتصان على " يلتزم العاملون بتعليمات وتوجيهات الصادرة من المسئول المباشر"، و" الإشراف المباشر والمتابعة المستمرة من قبل الرؤساء يؤدى إلى تحسين مستوى أداء العاملين" أعلى

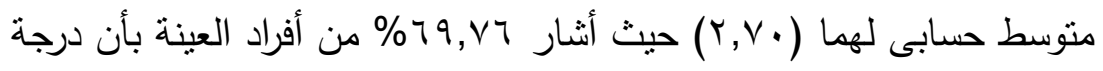
التحقق عالية مما بدل على إلتزام العاملين بالجامعة بالتعليمات ومتابعة

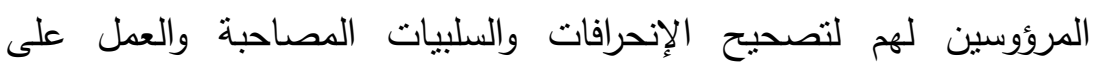
معالجتها أول بأول؛ بما ينعكس إيجابياً على تحسين مستوى وكفاءة أداءهم ، والمتابعة المستمرة من قبل القائمين في إدارة الجامعة على إعطاء متطلبات

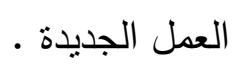

- وحول واقع تميز العاملون بالقدرة على تحمل مسئولية الأعباء اليومية جاءت العبارة (10) في المرتبة الثانية بمتوسط حسابي (r,T) حيث أنثار اء,rآ\% من أفراد العينة بأن ذلك يتحقق بدرجة كبيرة. 
- بينما جاءت العبارة رقم (r I) "يبذل العاملون الجها الكافى لإنجاز الأعمال

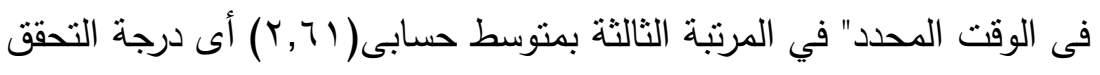

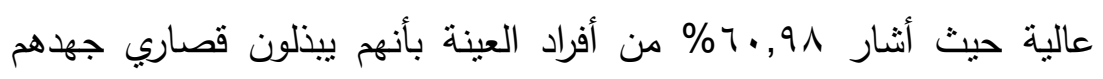

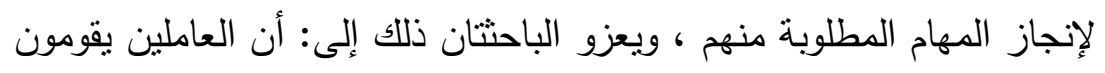

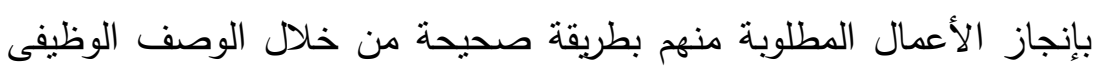

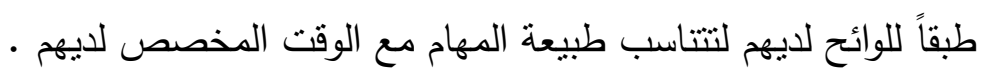

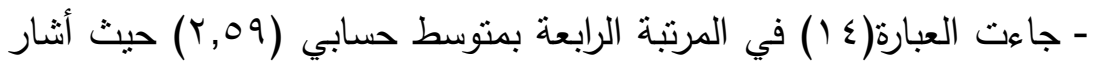

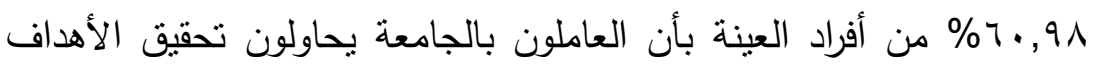

المطلوبة.

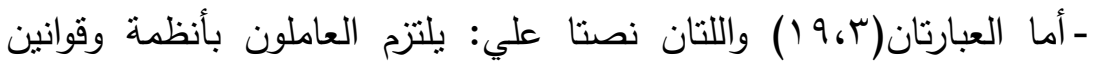

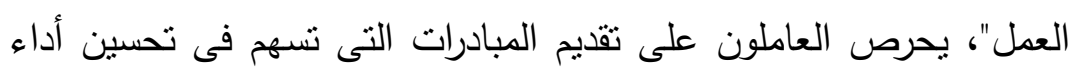

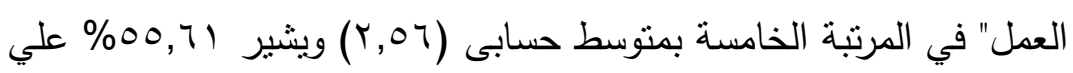

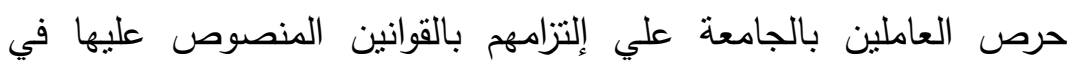

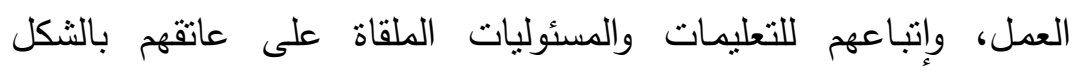

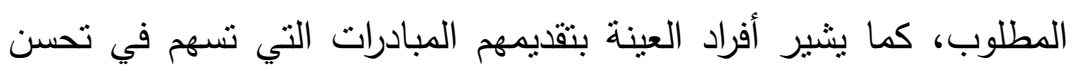

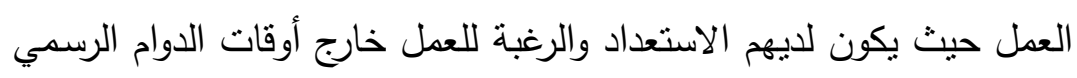
من أجل سرعة إنجاز بعض الأعمال المطلوبة منهم.

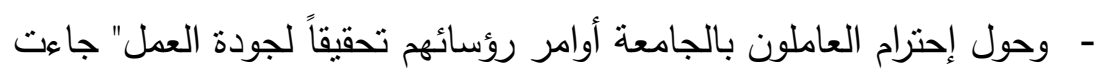

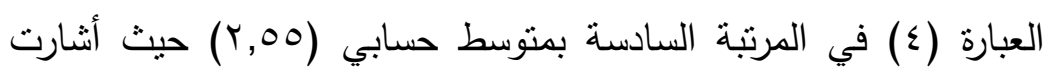
r r, §०\% من استجابات أفراد العينة بأن ذلك يتحقق بدرجة كبيرة. - - جاءت العبارة (YV) في المرتبة السابعة العمل بمتوسط حسابى (Y.0. وتتص علي " التتسيق والتعاون المستمر بين المستويات الإدارية لتحقيق

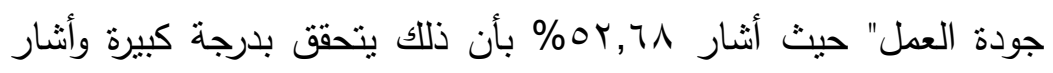




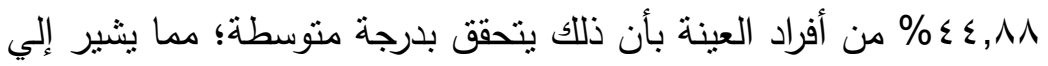
قصور إهتمام الجامعات بتحسين العلاقة بين العاملين فى الجامعة أثناء

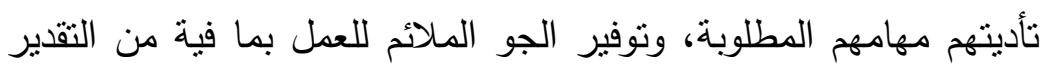
والإحترام لجميع العاملين.

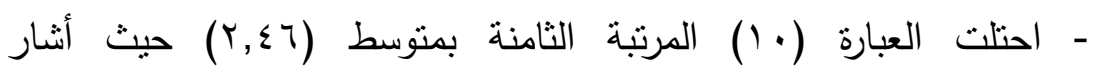

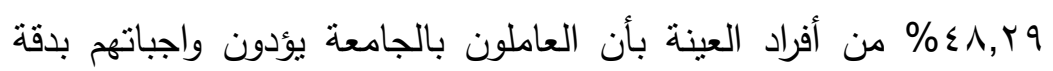

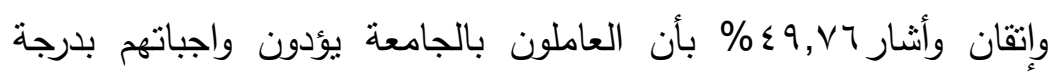
متوسطة. - - جاءت العبارة (V) وتتص علي قدرة للعاملين على التكيف عند حدوث

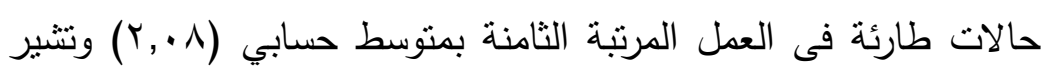

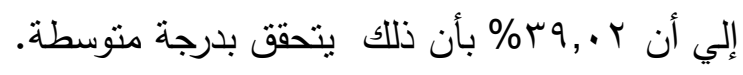

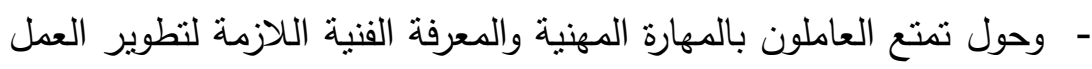

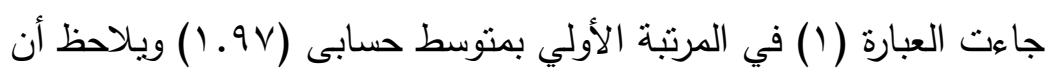

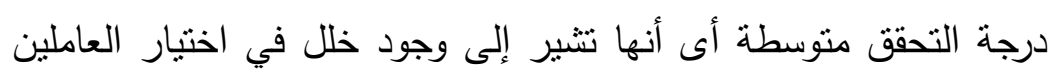

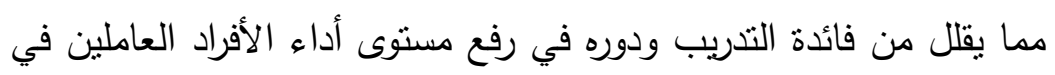
الجامعة.

وترى الباحثتان ضرورة معرفة وإلمام العاملين بطبيعة الأعمال الموكلة إليهه،

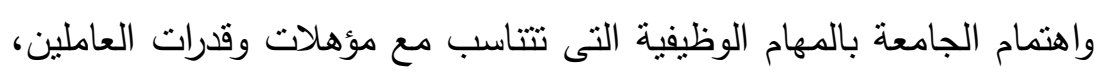

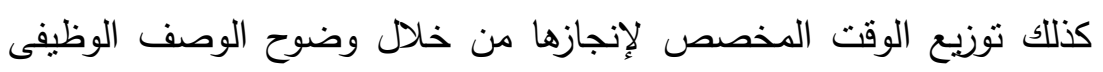
الخاص بالعمل . - وحول نوفير الجامعة التدريب المناسب للعاملين ، جاءت العبارة (r) في

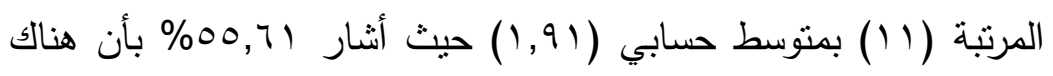
قصور في تحقيق الجامعة لذلك، ضعيف لذلك يجب إعادة النظر في عقد 
الدورات التدريبية بما يتلائم مع إحتياجات العمل، وأن لا تكرر هذه

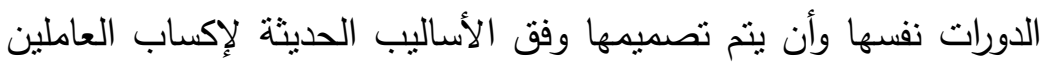
المهارات الجديدة اللازمة للعمل بما يتلائم مع التطورات الحديثة ومواكبة لاكبة التطورات في العمل الإداري وتحقيق الأهداف المرجوة منها. - - جاءت العبارة(^) وتتص علي" يتم تقييم الاداء الوظيفى للعاملين وفقا لإدان

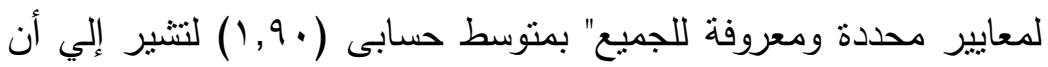

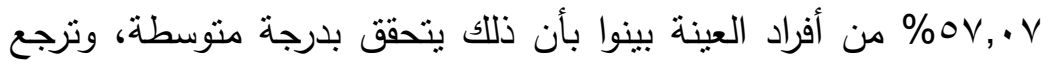
الباحثنان ذلك قصور توافر معايير مناسبة، ومحددة وثابتة لتقييم الأداء

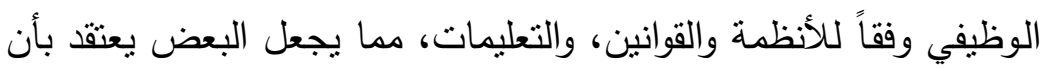
غالبية الترقيات أساسها المحاباة، ولم تستتد لمعايير الكفاءة بالأداء.

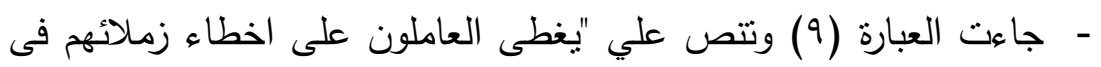

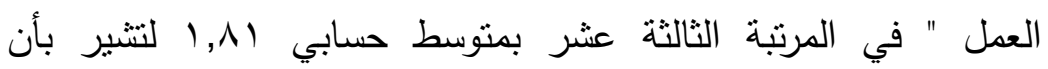

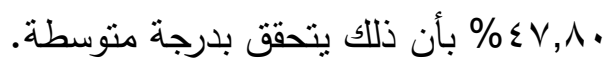

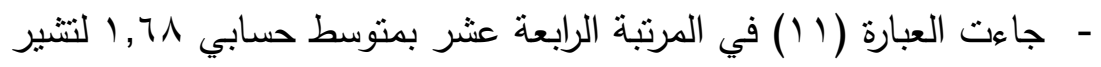
بأن مساعدة العاملون لرؤسائهم فى إنجاز العمل يتحقق بدرجة متوسطة.

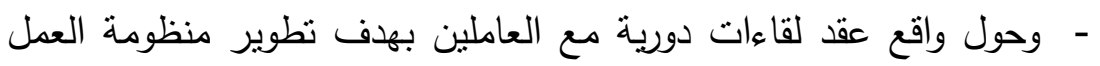

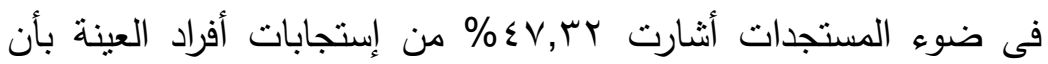
ذللك بتحقق بدرجة صغيرة بمتوسط حسابي 77 1, 1.

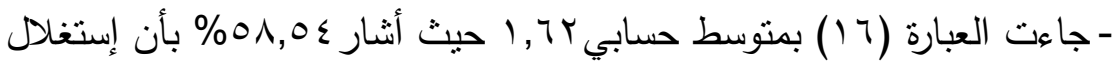

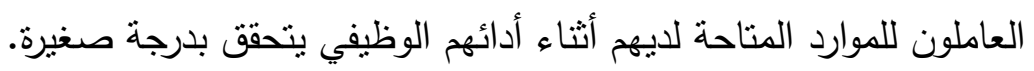

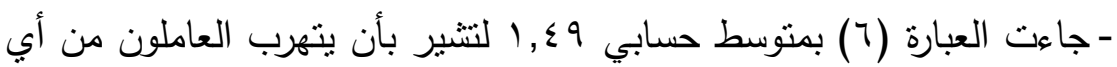

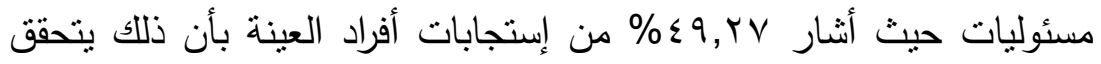
بدرجة صغيرة؛ مما يشير إلي حرص العاملون بالجامعة علي إلتزامهم بالعمل. 
- جاءت العبارة (0) في المرتبة الأخيرة بمتوسط حسابي •ب, إن حيث أثنار

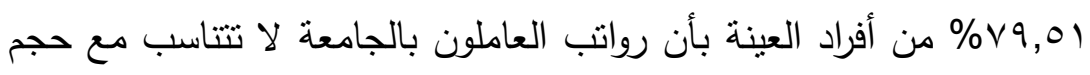
الأعمال التي يقومون بها. مما سبق يتضح القصور في الأداء الوظيفي للعاملين بالجامعة وقد يرجع هذا القصور إلي عدة عوامل منها : - ضعف الثقة بين العاملين ومرؤوسيهم. - القصور في تفويض السلطة من قبل المرؤسين للعاملين. - ضعف الإمكانات المتاحة بالجامعة. - ضعف التقدير المادي والمعنوي للعاملين بالجامعة. - قلة المكافآت للعاملين المتميزين. ثانياً: النتائج المتعلقة بالمحور الثاني: متطلبات تفعيل الثقة التنظيمية لدي

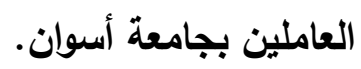

(أ): النتائج المتعلقة بالمجال الأول: واقع النقة بالقيادات الجامعية:

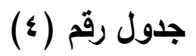

استجابات أفراد العينة عن البنود الخاصة بالمجال الأول

\begin{tabular}{|c|c|c|c|c|c|c|c|c|c|c|}
\hline \multirow{2}{*}{ إتجاه } & \multirow[t]{2}{*}{ ت } & \multirow{2}{*}{ المرتط } & \multicolumn{2}{|c|}{ غير متوفر } & \multicolumn{2}{|c|}{ إلي حد ما } & \multicolumn{2}{|c|}{ متوفز } & \multirow[t]{2}{*}{ الععبارة } & \multirow[t]{2}{*}{$\hat{\imath}$} \\
\hline & & & $\overline{\%}$ & 15 & $\%$ & ك & $\%$ & ك" & & \\
\hline عالٍ & 1 & r.7. & $\because \cdots$ & - & $\varepsilon \ldots$ & $\Lambda T$ & $7 .$. & Tr & لقدرتهم واستيار القيادات الجامعية طبقاً & 1 \\
\hline متوسط & $\wedge$ & 1.19 & rV.rT & 07 & 07.09 & 117 & 17.1. & זr & تلقعام القيادات الجامعية الدعم التنظيمى & r \\
\hline متوسط & 7 & Y.0 & $r \leq . \wedge \Lambda$ & 01 & $\varepsilon 0 . \mathrm{rV}$ & 94 & rq.V7 & 71 & تضع القيادات الجامعية نموذجا للشفافية & $r$ \\
\hline عالٍ & $r$ & t.or & r.q. & $\wedge$ & $\varepsilon$. & AT & 07.1. & 110 & 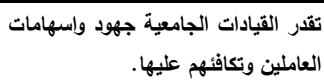 & $\varepsilon$ \\
\hline متوسط & 9 & 1.97 & $r v . v$ & $V_{7}$ & $T \cdot . \leq \leq$ & Tr & גד.T & $T V$ & 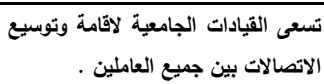 & 0 \\
\hline متوسط & $r$ & r.th & rT.q. & $\leq 9$ & rr.q. & $\leq 9$ & or.t. & $1 . V$ & تنظر القيادات الجامعية بعين الاعتبار & 7 \\
\hline
\end{tabular}




\begin{tabular}{|c|c|c|c|c|c|c|c|c|c|c|}
\hline متوسط & 0 & r. $1 \leqslant$ & 19.01 & $\varepsilon$. & $\sum \tau . \Delta \mu$ & 97 & דוד.ז" & 79 & 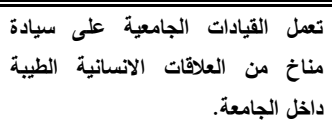 & v \\
\hline متوسط & 1 & 1.09 & $0 \leqslant . \pi$ & $\begin{array}{l}11 \\
r^{\prime}\end{array}$ & r.t. & 77 & $15.1 \mathrm{~V}$ & rV & بهائق الامقاص القيادات الجامعية ومعرفتها & $\wedge$ \\
\hline متوسط & $\bar{v}$ & 1.94 & $r, K r$ & $T \varepsilon$ & $\leqslant 0.10$ & $9 \varepsilon$ & rY.qT & $\varepsilon V$ & 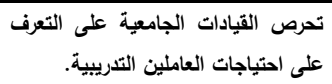 & 9 \\
\hline متوسط & $\varepsilon$ & r.10 & $11.0 \varepsilon$ & rA & $\leqslant \vee . \wedge$. & 91 & דוד.זץ & 79 & المعلومات الللازمة لأداء العمل باستمرار. & 1. \\
\hline
\end{tabular}

من خلال ما توضحه لنا نتائج الجدول رقم (ع) فإننا نسجل مستوى منوسط ومرتفع فى مختلف العبارات ببعد التقة التظظيمية للقيادات الجامعية، وذللك كما يلي - جاءت أعلى قيمة للمتوسط المرجح (T,Y) بالنسبة للعبارة ( (1) والتى تتص على" تضع القيادات الجامعية الرجل المناسب فى المكان المناسب ووفق القدرات المناسب" حيث أجاب أفراد مجتمع البحث بنسبة . 7\% بأن ذلك يتحقق بدرجة كبيرة ، وهى نسبة دالة على تحقيق أهداف الجامعة ورسالتها، أما نسبة • ع فأنشاروا بأن ذلك يتحقق بدرجة متوسطة ؛ وهذا بدل على أن هنالك عاملين لديهم مهارات وخبرات وإمكانات تؤهلهم فى إمتلاكهم مناصب اعلى مما هو مناح لديهم، وتعزى الباحثتان ذلك إلى : أن وضع الرجل المناسب في المكان المناسب هو الأساس في نجاح العمل الجامعي وتطويره، إذ أن الله سبحانه وتعالى خلق الأفراد بقرات مختلفة، فالجامعة كمؤسسة علمية تضم عاملين من طاقات وقدرات مختلفة بما تتفرد به كل شخصية عن الأخرى، لذلك فإن أب خلل في ذلك ينعكس سلباً على أي عمل، فمن الضرورى إسناد المناصب بدافع الكفاءة العلمية بعيداً عن الاعتبارات الثخصية والذاتية والحزبية والتتظيمية ؛ لأن هذه الأمور بعيدة عن العمل الجامعي؛ بالإضافة إلى المهام 
الجديدة للقيادات الجامعية تعطيهر صلاحية إتخاذ القرارات المناسبة، وتحليهم

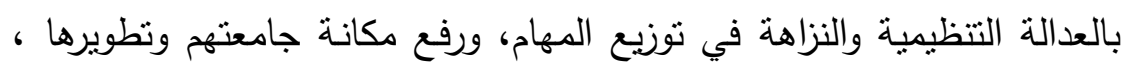
وأهمية إختبار العاملين على أسس سليمة وموضوعية حتى يرفع كفاءة أدائهم في العمل. - جاءت العبارة (§) في المرتبة الثانية وتتص على " تقدر القيادات الجامعية

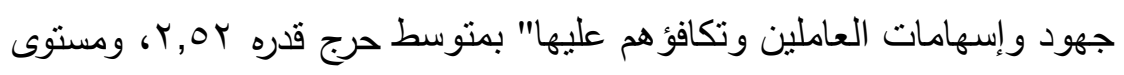

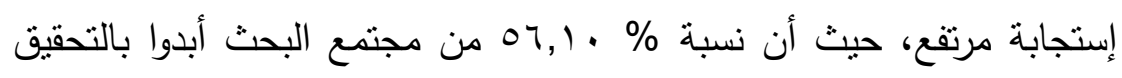

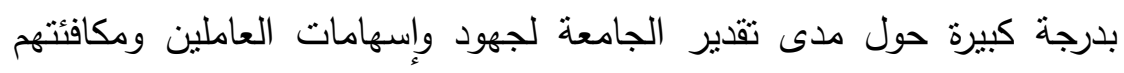
على ذلك في كل مرة ، وذلك بما بتماثى مع التطور الذي تشهده الجامعة فيما

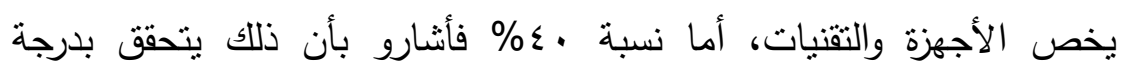

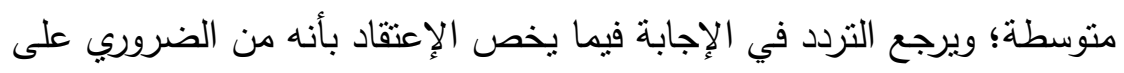

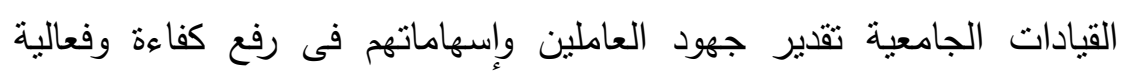

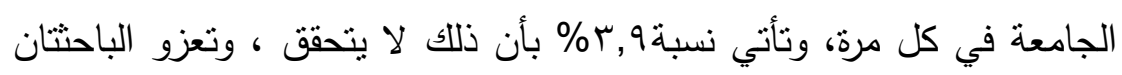

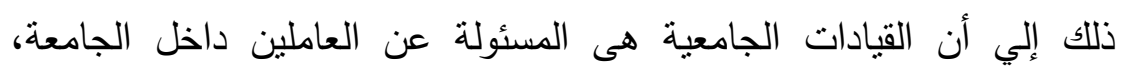

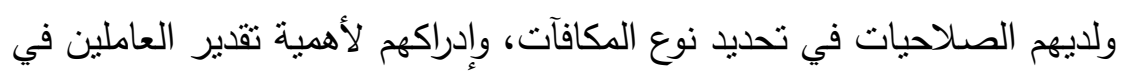

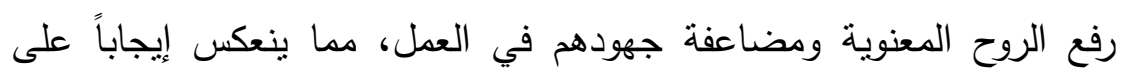

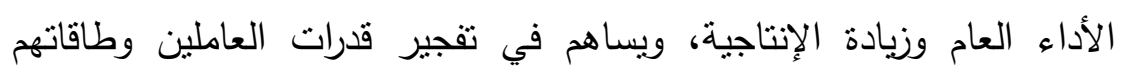

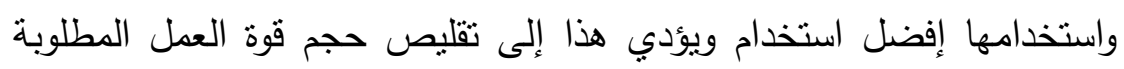
من قبل الجامعة؛ مما ينعكس بدوره علي تقليل التكاليف التي تتحملها الجامعة،

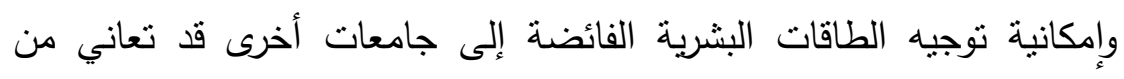
نقص في حجم قوة العمل، وكذلك تحقيق الرضا الوظيفى للعاملين لما يحصلون عليه من حوافز وهذا بدوره يساعد في حل الكثير من المشاكل الجامعية. 
- جاءت العبارة (ج) " تنظر القيادات الجامعية بعين الإعتبار لمصالح العاملين

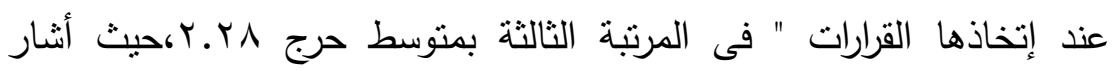

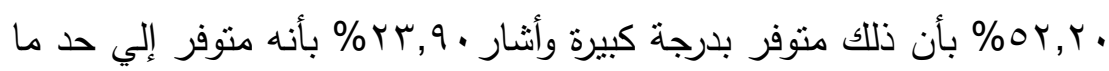

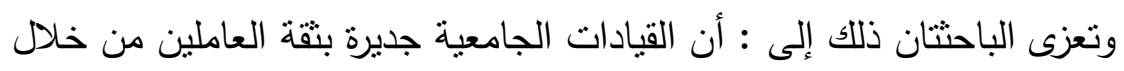

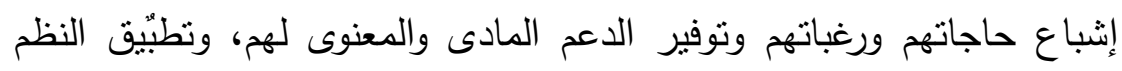

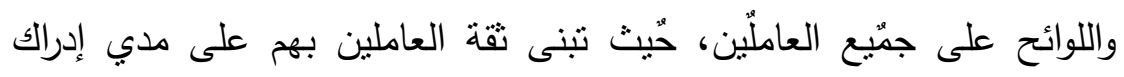

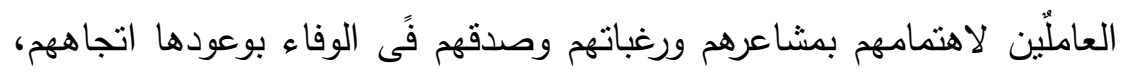

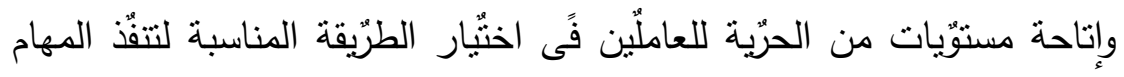

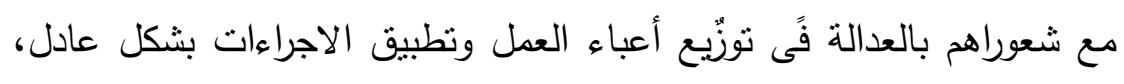
بما يسهم فى زُّيادة تحسين كفاءة العاملين بالجامعة.

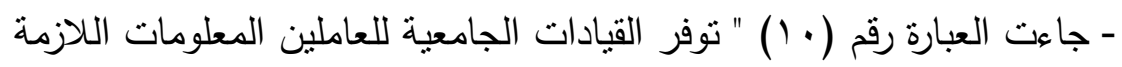

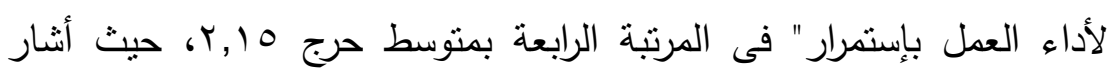
\%乞 \%,A. .

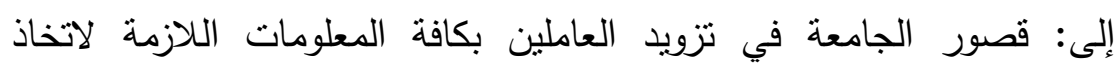
القرارات المناسبة لضمان سير العمل، ومساعدتهم على ممارسة وظائفهم في لجي التخطيط والتنظيم والسيطرة، مع ضرورة جمعها وتصنيفها وتخزينها ومعالجتها

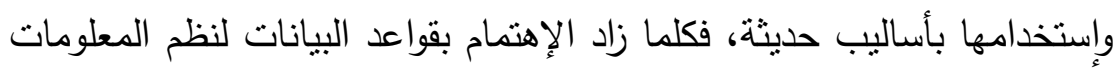

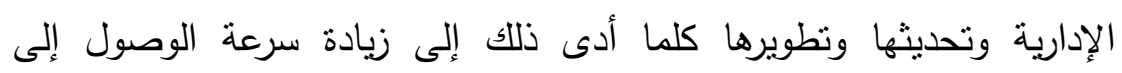

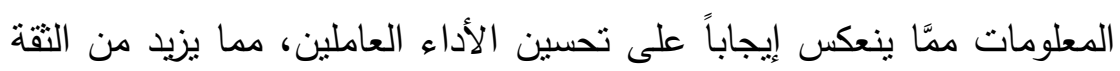

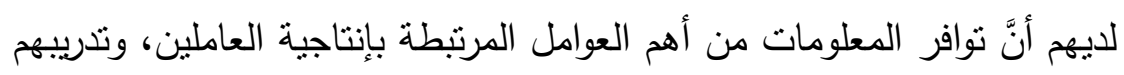

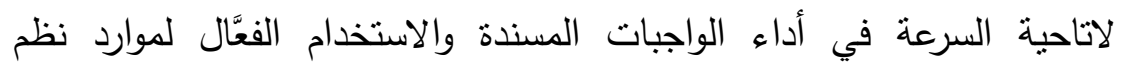
المعلومات الإدارية والتكنولوجيا يزيد من الكفاءة والإنتاجية. 


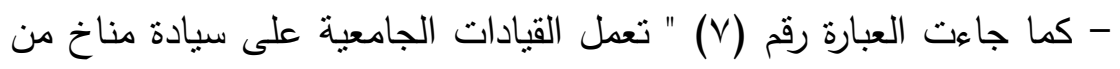
العلاقات الانسانية الطيبة داخل الجامعة " فى المرتبة الخامسة بمتوسط ع (Y,Y،

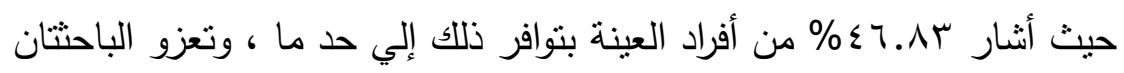

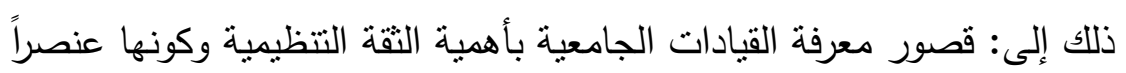
أساسياً في العلاقات الإنسانية التى تعمل على خلق جو من الثقة والإحترام

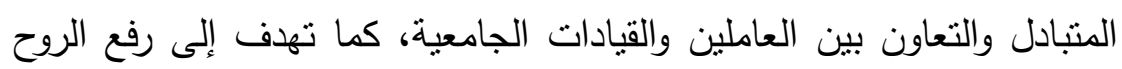

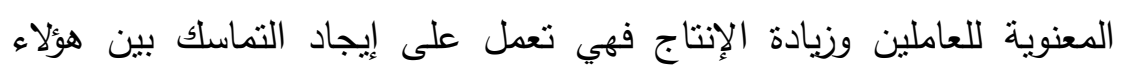

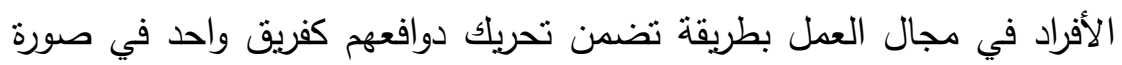

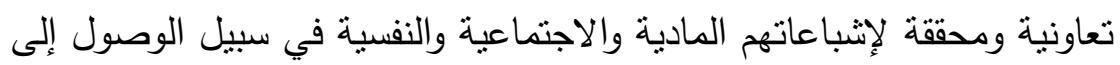
الأهداف المشتركة بينهم وبين الجامعة، مما يخلق روح التتافس البناء وإجراء

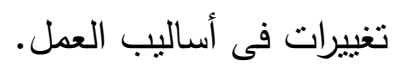

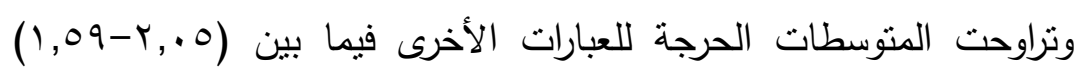

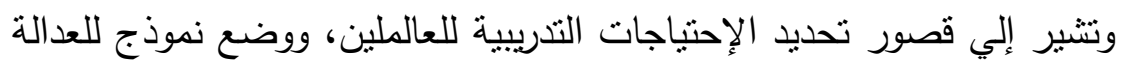

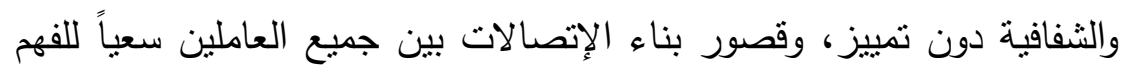
المشترك وقصور الدعم التتظيمي للعاملين بجامعة أسوان.

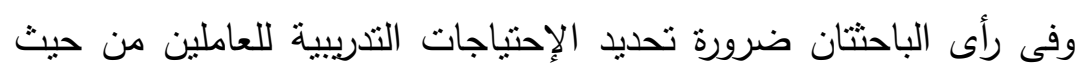
الأسلوب المتبع في تحديد الإحتياجات حسب إحتياجات العمل والأولوية وبناء

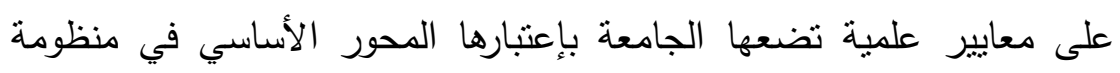
العملية التدريبية بما يتتاسب مع إكتساب المهارات والقدرات المطلوبة، وإختبارهم

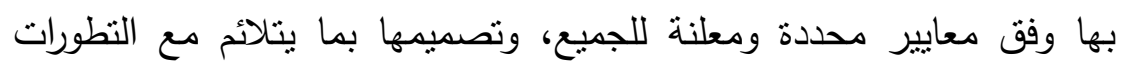

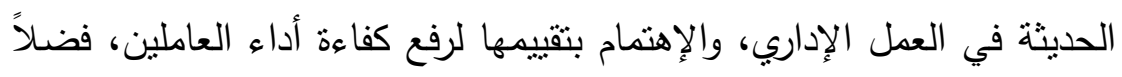

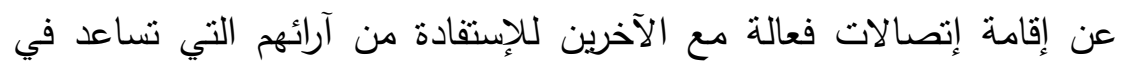

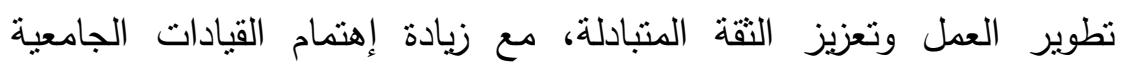


للعاملين من حيث التقدير والإحترام المتبادل بينهم، وتحقيقهم الإستقرار والأمن الوظيفي، ومعرفتهم بدقائق أمور العمل حتى تكسب ثقة العاملين بالجامعة، وتهيئة بيئة تتظيمية تدعم إحتياجاتهم مادياً ومعنوياً، من خلال تطبيق نموذج بون للشفافية والنزاهة والعدالة بين العاملين دون تمبيز شخص عن آخر بما يخدم أهداف الجامعة التي تسعى إلى تحقيقها.

المجال الثانى : واقع الثقة التظيمية بين العاملين والرئيس المباشر :

$$
\text { جدول(0) }
$$

استجابات أفراد العينة عن البنود الخاصة بالمجال الثاني

\begin{tabular}{|c|c|c|c|c|c|c|c|c|c|c|}
\hline \multirow{2}{*}{ الاتجاه } & \multirow[t]{2}{*}{$ت$} & \multirow[b]{2}{*}{ المتوسط } & \multicolumn{2}{|c|}{ غير متوفر } & \multicolumn{2}{|c|}{ إلي حد ما } & \multicolumn{2}{|c|}{ متوفر } & \multirow[t]{2}{*}{ العبارة } & \multirow[t]{2}{*}{ s } \\
\hline & & & $\%$ & I & $\%$ & ك بץ & $\%$ & كt & & \\
\hline منتسط & $r$ & r.rV & $r T . \leqslant 1$ & $\leqslant \Lambda$ & Y7.r & $0 \leqslant$ & $0 \cdot, r \leq$ & 1.4 & 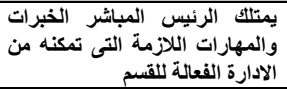 & 1 \\
\hline عال & 1 & $T .00$ & $\cdot$ & $\cdot$ & $\leqslant \leqslant . \wedge \wedge$ & 94 & $00,1 Y$ & $11 \%$ & 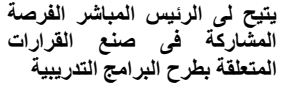 & $r$ \\
\hline متوسط & $V$ & T. $\cdot \varepsilon$ & 17.09 & $r \leqslant$ & $\pi$ TY. & IYA & $r \cdot .91$ & $\leqslant T$ & 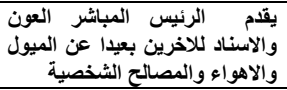 & $r$ \\
\hline عالٍ & $r$ & T. $\leqslant \Lambda$ & $1 \% .77$ & $r \wedge$ & $r \leq . r q$ & 0. & 71.90 & ITV & 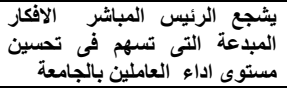 & $\varepsilon$ \\
\hline متوسط & 0 & T.Y. & 9.87 & $r \cdot$ & $7 . .59$ & $T K \varepsilon$ & rq.V7 & 71 & 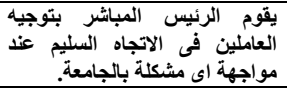 & 0 \\
\hline متوسط & $\Lambda$ & T. .1 & ro.10 & or & $\sum V . r Y$ & $9 V$ & $r 7 . \wedge r$ & 00 & بالجامية لتبادل وليس المبات نظر اجتماعات العاملين & 7 \\
\hline متوسط & 9 & 1.99 & $r \leqslant . \wedge \wedge$ & 01 & $01 . Y Y$ & 1.0 & rr.q. & $\sum 9$ & 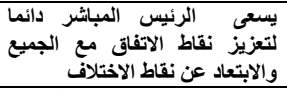 & $\bar{v}$ \\
\hline متوسط & $\varepsilon$ & T.YO & r.9. & $\Lambda$ & TV.TY & $1 \% 1$ & 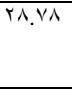 & 09 & 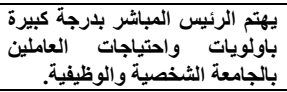 & $\wedge$ \\
\hline متوسط & 1. & 1.94 & TI.YT & $7 \leq$ & $\leqslant 0.10$ & $9 \leqslant$ & rY.qT & $\sum V$ & يثق الرئيس المباشر باعطاء مهام & 9 \\
\hline
\end{tabular}




\begin{tabular}{|l|l|l|l|l|l|l|l|l|l|l|}
\hline & & & & & & & & & & \\
\hline & & & & & & & \\
\hline
\end{tabular}

من خلال ما توضحه لنا نتائج الجدول رقم (0) فإننا نسجل مستوى متوسط

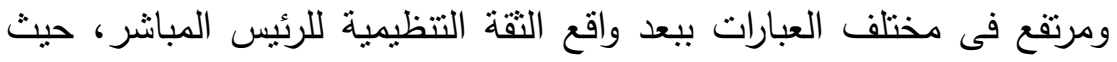

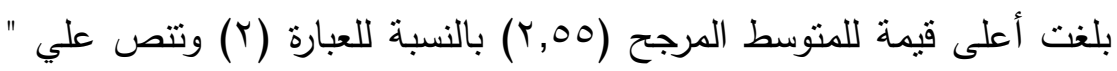

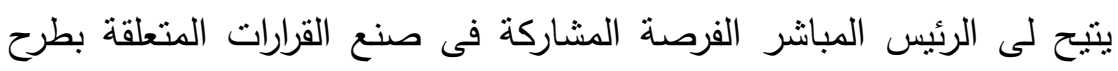

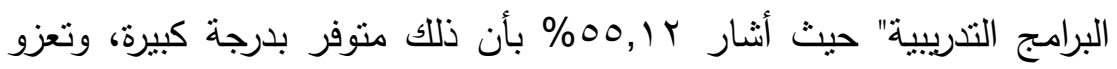

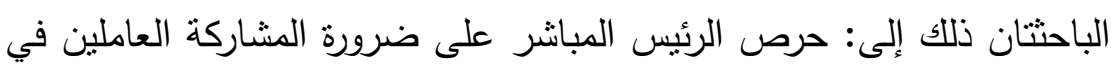

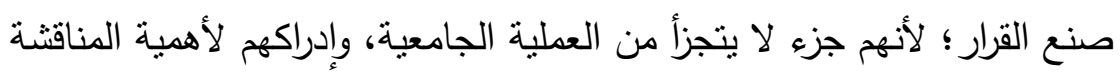

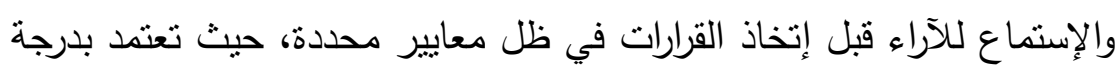

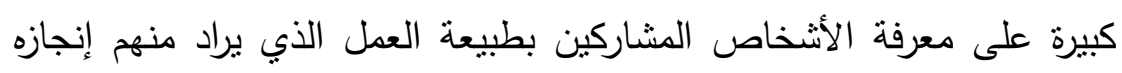

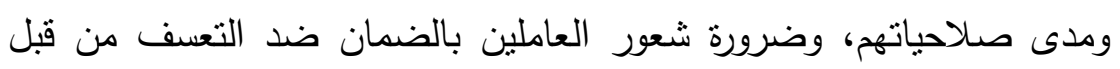
الإدارة أو أية جهة أخرى وعدم إنخاذ إجراءات رادعة نتيجة ممارسته حقه في

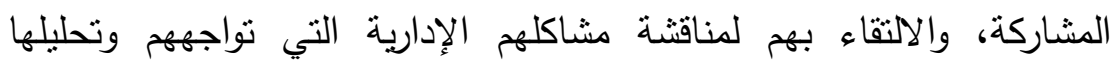
ومحاولة الوصول إلى أفضل الحلول الممكنة لها مما يخلق التقة بينهم.

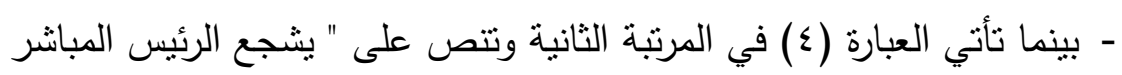

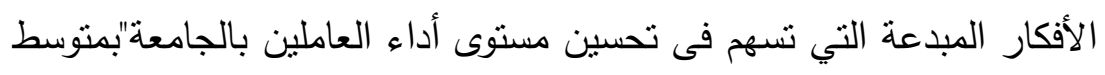

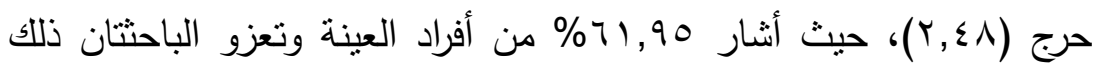

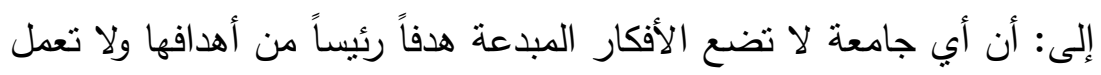

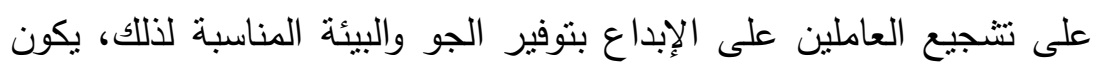

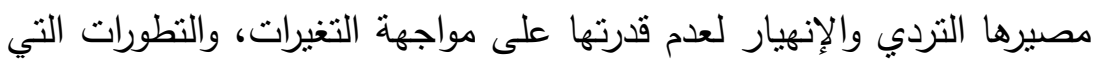

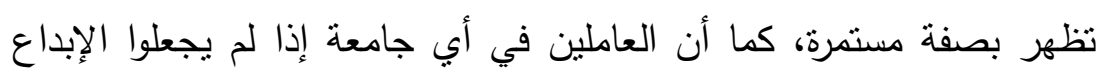

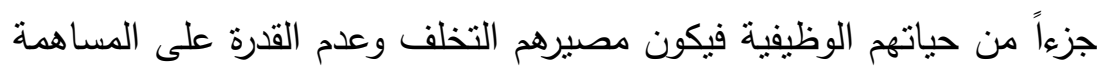

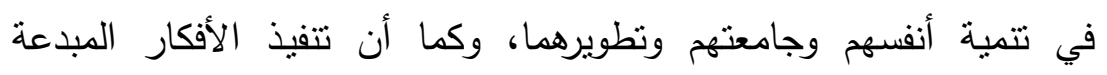


للعاملين يقع في إطار مسؤولية الرئيس المباشر والصلاحيات الممنوحة لهم

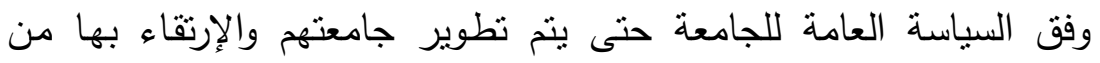
خلال وسائل متعددة، وتشجيعهم لها مع رعاية المواهب والقدرات الإبداعية لهاهية للديهم مما يدفعهم للاستماع إلى مقترحاتهم والعمل بها.

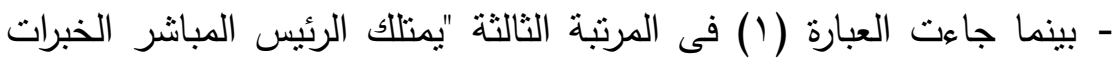

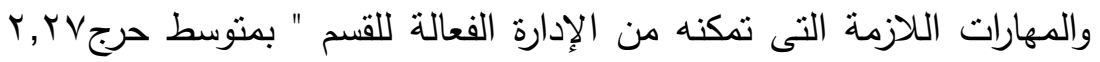

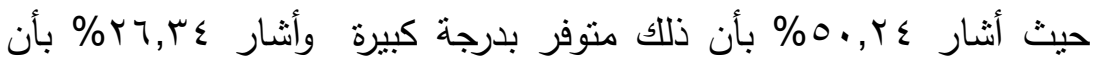
ذللك يتوفر إلي حد ما، وجاءت العبارة (^) في المرتبة الرابعة "يهتم الرئيس المباشر بدرجة كبيرة بأولويات وإحتياجات العاملين بالجامعة الثخصية

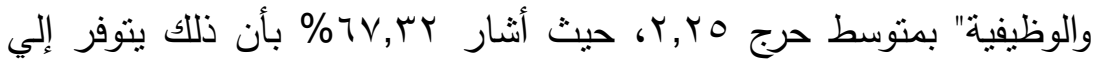

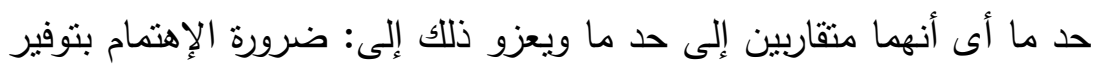

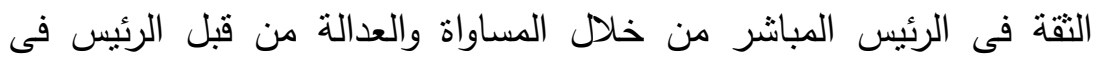
معاملة الأخرين، ومحافظته على وعوده، وإمتلاكه كثير من المعرفة والخبرة

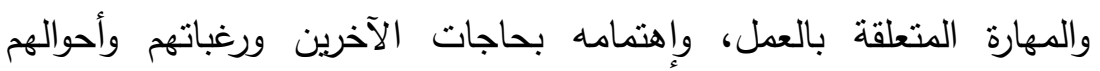

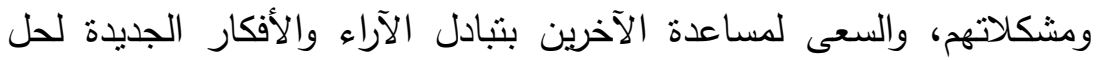

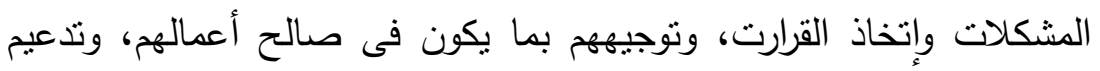

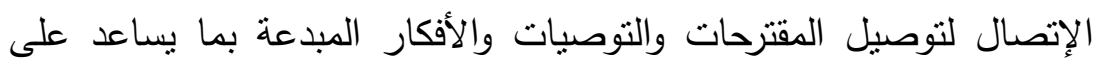

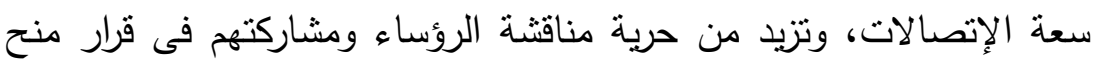
عوائد للمبدعين، وعدم الخوف من مساءلة الرئيس حول تجريب الأفكار الجديدة والحصول على الدعم المعنوى للأعمال المبتكرة.

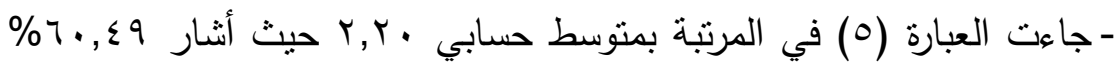

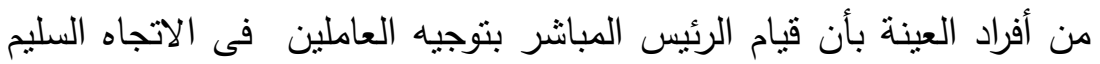
عند مواجهة اى مشكلة بالجامعة يتوفر إلي حد ما. 


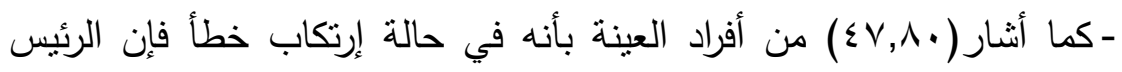
المباشر مستعداً للمسامحة والنسيان.

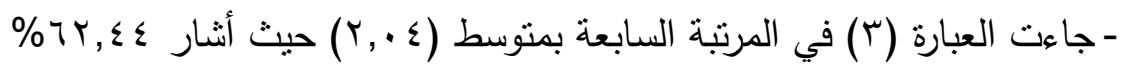
بأن تقديم الرئيس المباشر العون والإسناد للآخرين بعيداً عن الميول والأهواء

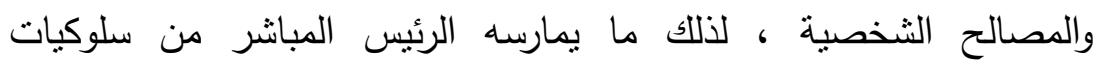

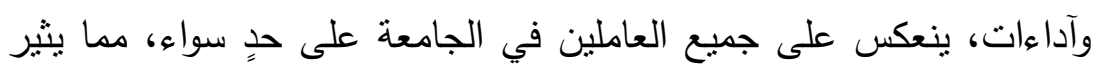

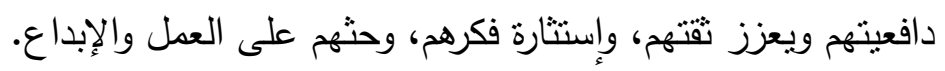

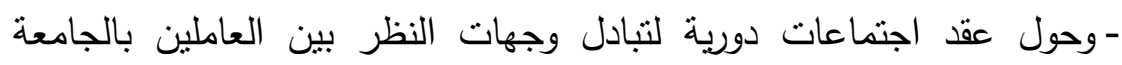

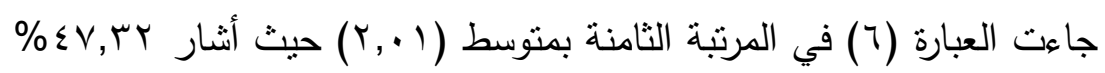

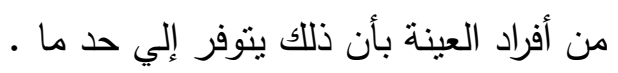

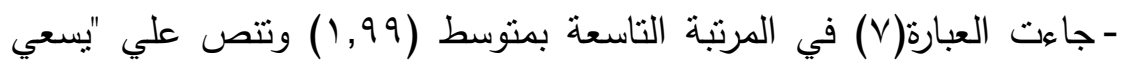

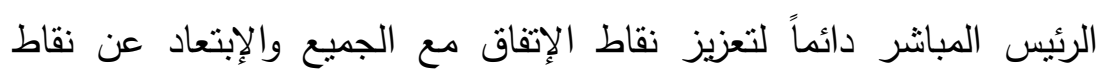

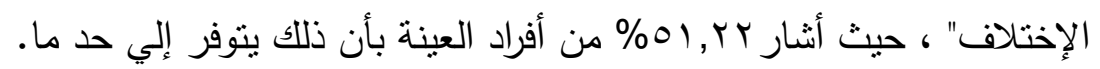
يتضح مما سبق أن هناك قصور في الثقة التنظيمية بين العاملين والرئيس

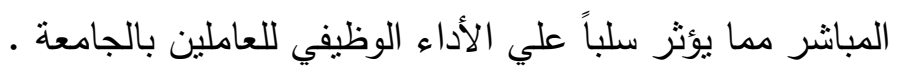

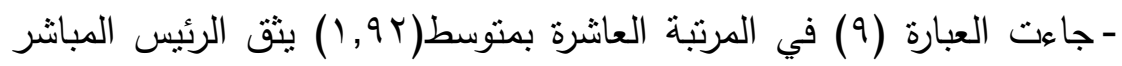
باعطاء مهام محددة وفقاً لمسئولية كل فرد حيث أثنار العينة بأن ذلك يتوفر إلي حد ما.

لذللك لابد من تدعيم التقة بين العاملين ومرؤوسيهم وإبداء كلا منهم مزيد بأيد

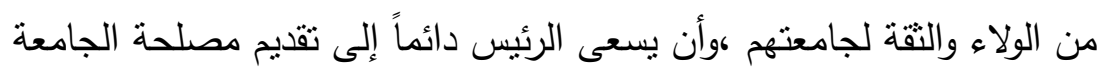

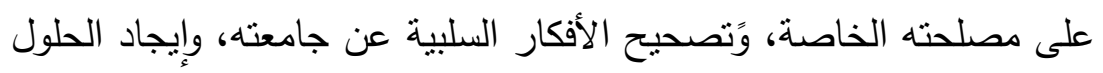
والإقتراحات بشأنها، وبهذا يعد جزء من نجاحه وتميزه المهني، ومساعدة

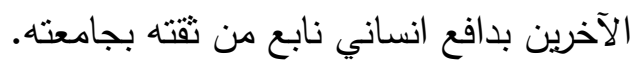


كذللك بناء تصورات إيجابيـة للعاملين تجاه التقة التنظيمية في الرئيس المباشر ، التي نتشير إلى أن هناك روابط متزنة تحكم طبيعة العلاقة بين ليناه

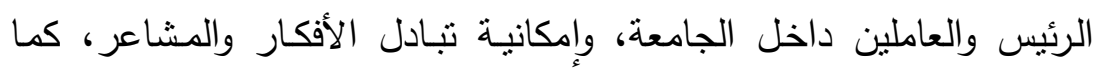

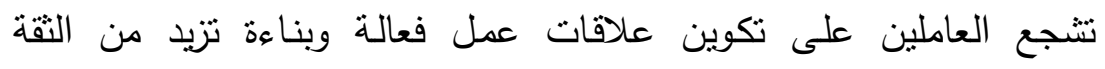
المتبادلة بين الرئيس والعاملين في الجامعة.

المحور الثالث : الثقة التظيمية بالزملاء :

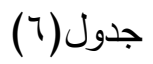

إستجابات أفراد العينة عن البنود الخاصة بالمجال الثالث

\begin{tabular}{|c|c|c|c|c|c|c|c|c|c|c|}
\hline \multirow[t]{2}{*}{ الآجاه } & \multirow[t]{2}{*}{$\ddot{\Delta}$} & \multirow[b]{2}{*}{ وزن } & \multicolumn{2}{|c|}{ غير متوفر } & \multicolumn{2}{|c|}{ إلي حد مـا } & \multicolumn{2}{|c|}{ متوفر } & \multirow[t]{2}{*}{ العبارة } & \\
\hline & & & $\%$ & ك & $\%$ & تو & $\%$ & كب & & \\
\hline عال & 7 & דיזי & 17.1 & rr & ו. & 70 & or.r. & $1 \cdot v$ & 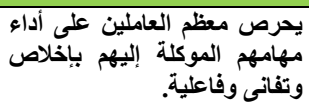 & 1 \\
\hline متوسط & $1 \cdot$ & I. $\wedge V$ & ro. 10 & or & 7.91 & 1 tro & $1 \mathrm{IV}$ & $r V$ & 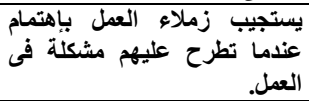 & r \\
\hline متوسط & $V$ & r. & $r Y \leq \varepsilon$ & $\varepsilon 7$ & $r \varepsilon .10$ & $V$. & $\leqslant T \leqslant 1$ & 19 & 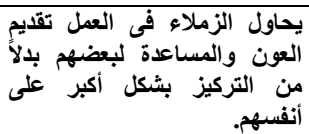 & r \\
\hline عال & 1 & $r .7 r$ & $\because \cdots$ & • & rᄉ. o & $\mathrm{VA}$ & 71.90 & ITV & والثبادل & $\varepsilon$ \\
\hline متوسط & 9 & $1 . \wedge \wedge$ & ro. 10 & or & $7 .$. & MT & $1 \leqslant .10$ & rq & لانفبون الزملاء لغيزهم ما يحبونه & 0 \\
\hline عال & 0 & q.r. & 0.10 & Ir & $\varepsilon 9 . \vee 7$ & $1 . r$ & $\varepsilon \varepsilon . \Gamma q$ & 91 & 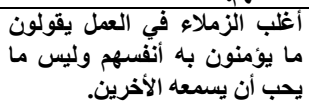 & 7 \\
\hline عال & $r$ & $r .00$ & r.q. & $\wedge$ & $r v . \cdot v$ & $V T$ & $09 . r$ & $\mid$ & 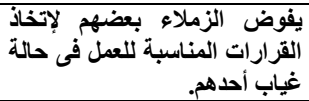 & V \\
\hline متوسط & $\Lambda$ & $r . v$ & 11.81 & r $\varepsilon$ & $79 . \mathrm{rV}$ & $1 \leqslant r$ & 19.4 & rq & توجد ثقة متبادلة بين الزملاء في & $\wedge$ \\
\hline عال & $\varepsilon$ & $r . \leqslant r$ & 1.90 & $\varepsilon$ & ד7.77 & 11. & $\varepsilon \varepsilon . r q$ & 91 & رغبوم الزملاء بتوجيه بعضي عمه شئ إذا & 9 \\
\hline عال & $r$ & $r \leqslant q$ & r.q. & $\wedge$ & EY.q & ᄉᄉ & or. IV & 1.9 & يكون الزملاء في العمل علي & 1. \\
\hline
\end{tabular}




\begin{tabular}{|l|l|l|l|l|l|l|l|l|l|l|}
\hline & & & & & & & & & & \\
\hline
\end{tabular}

من خلال ما توضحه لنا نتائج الجدول رقم (0) فإننا نسجل مستوى متوسط ومرتقع فى مختلف العبارات ببعد التقة التظظيمية للزملاء، وذلك كما يلي: - حيث أن أعلى قيمة للمتوسط الحرج بلغ باج, بالنسبة للعبارة (1) التى تتص على" يتبادل الزملاء البيانات والمعلومات بشكل واضح وصريح لأداء العمل وحل المشكلات" حيث أشار 90 , آ7\% من أفراد العينة بأن ذلك يتوفر بدرجة كبيرة، وتعزى الباحثتان ذلك إلى : أن هناك علاقات تعاونية منبادلة وميل موقفى إيجابى بين العاملين من حيث الاعتماد المنبادل والإشتراك فى لئ الأفكار والمعلومات والإتصالات المفتوحة بينهم، فإمتلاك زملاء العمل الخبرة المتعلقة بالعمل سوف يساهم فَى تحسيّن مستوى ثقة الفرد فَّى نفسه وزملائه وذلك من خلال تبادل هذه البيانات والمعلومات بُين الزملاء داخل وحدة العمل

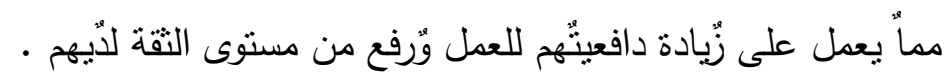
- جاءت فى المرتبة الثانية العبارة التى تتص على" يفوض الزملاء بعضهم

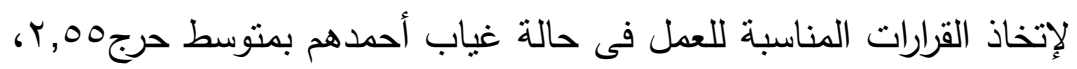

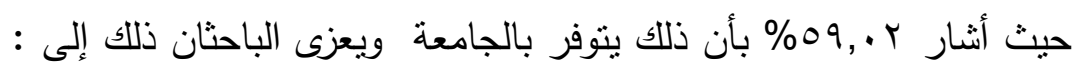
ان عملية تفويض الزملاء لإتخاذ القرارات تساعد على تحسين اداء العاملين حيث يشعرهم بثقتهم بأنفسهم والقدرة على الأداء مما ينعكس ايجابا على لئ لاعلى القيام بالعمل، بالإضافة إلى تحقيق سرعة أداء العمل الإدارى، والمرونة الإدارية والتكيف مع الظروف المختلفة، مما ينمى روح المبادرة لدى العاملين. - بينما جاءت فى المرتبة الثالثة العبارة التى تتص على " يكون الزملاء في العمل علي حذر مع بعضهه. " بمتوسط حرج 9. و. حيث أثنار 
\%०r,IV من أفراد العينة بأن ذلك يحدث بالفعل في الجامعة، ويعزو الباحثتان ذلك إلى ضعف الثقة بين الزملاء وبعضهم البعض.

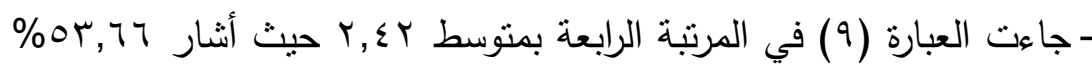

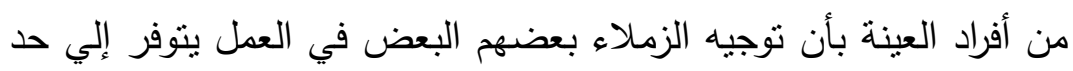

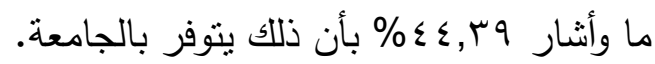

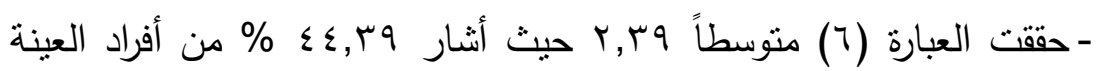

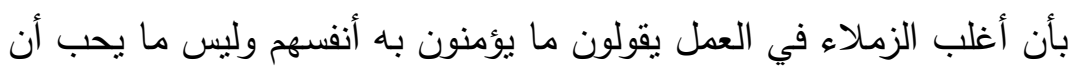

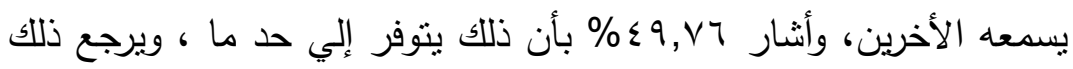

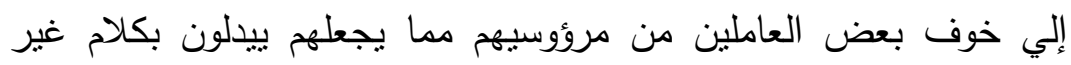

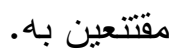

- وحول حرص معظم العاملين على أداء مهامهم الموكلة إليهم بإخلاص باص

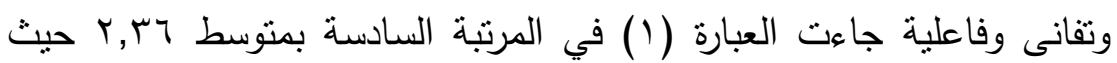

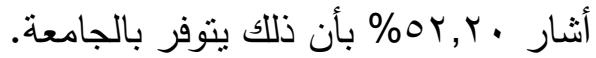

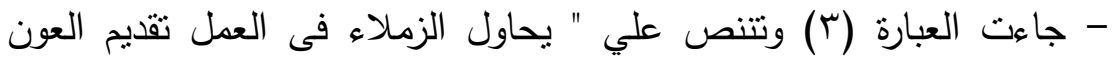

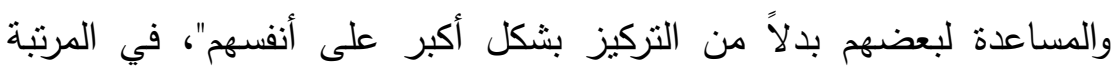

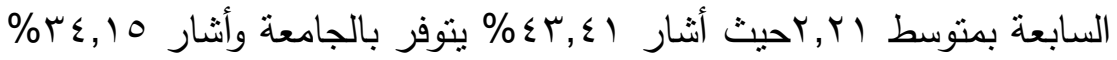

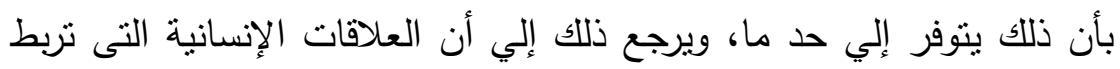
بين العاملين بعضهم بزملائهم تفرض عليهم المعاملة الحسنة ، وأن مراعاة مشاعر الزملاء فى العمل لها الأثر الايجابى وتتعكس على إنتاجية الجامعة .

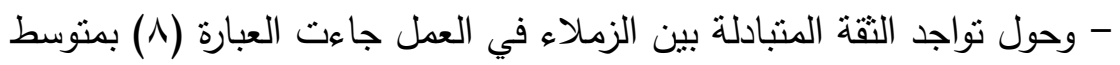

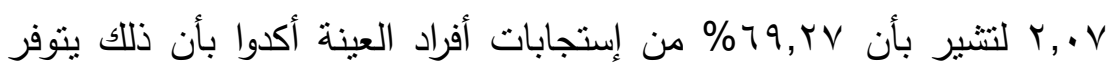
إلي حد ما بالجامعة علي الرغم من أن الثقة بين العاملين بالجامعة من أحد الحدان

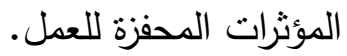


جاءت العبارة (0) وتتص علي يحب الزملاء لغيرهم ما يحبونه لأنفسهم في

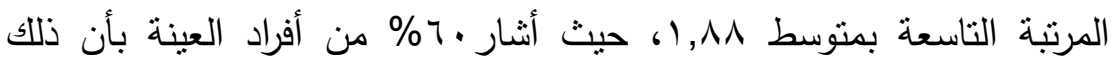

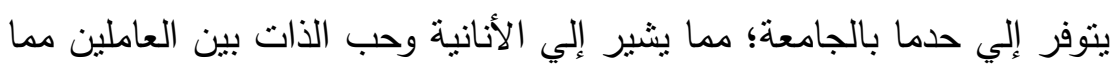

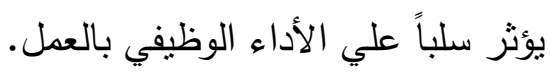

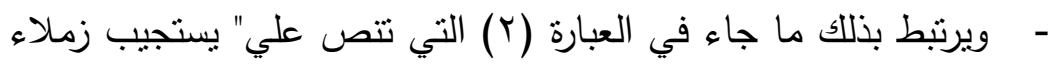
العمل بإهتمام عندما تطرح عليهم مشكلة فى العمل" في المرتبة

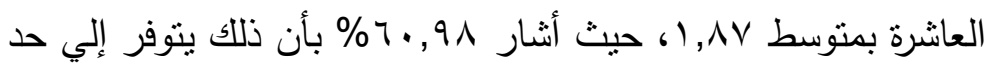

$$
\text { ما بين العاملين بالجامعة . النتائج والتوصيات: }
$$

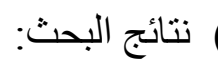

أظهرت الدراسة الميدانية مجموعة من النتائج المتعلقة بواقع الأداء الوظيفي وواقع الثقة التنظيمية، وذلك كما يلي

أولاً: النتائج المتعلقة بواقع الأداء الوظيفي لدي العالين بجامعة ولئ أسوان:

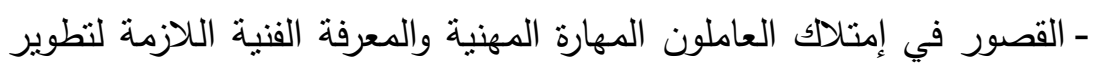

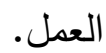

- قصور تدريب العاملين بالجامعة لتمكنهم من أداء أعمالهم بصورة جيدة.

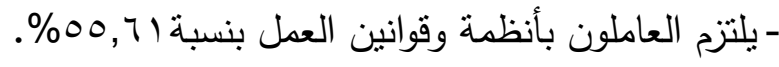

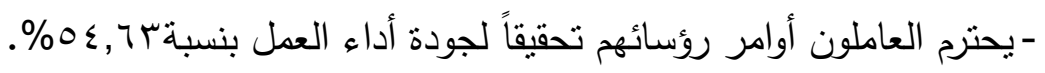
- قلة رواتب العاملون بالجامعة مقارنة بحجم مهامهم.

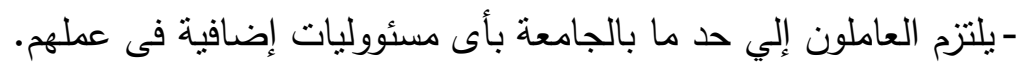
- ضعف العاملين على التكيف عند حدوث حالات طارئة فى العمل. - قصور تقييم الأداء الوظيفى للعاملين وفقا لمعايير محددة ومعروفة للجميع. - يغطى العاملون على أخطاء زملائهم فى العمل. - يؤدى العاملون واجباتهم الوظيفية بدقة واتقان. - 0 . - 
- يهتم معظم العاملون بمساعدة رؤسائهم فى إنجاز العمل. - القصور في بذل العاملون جهد كافى لإنجاز الاعمال فى الوقت المحدد.

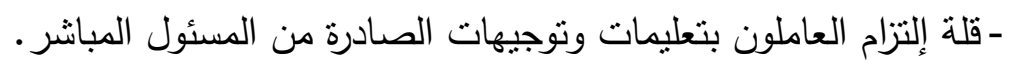
- يحاول العاملون بالجامعة ان يحققوا الأهداف المطلوب إنجازها. - يتميز العاملون إلي حد ما بالقدرة على تحمل مسئولية الاعباء اليومية. - قصور العاملون في إستغلال الموارد المتاحة لديهم أثناء ادائهم الوظيفى.

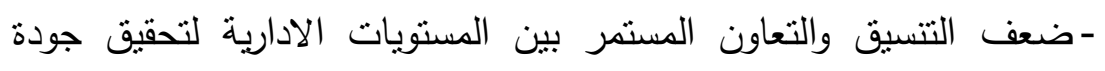
العمل. - قلة عقد لقاءات دورية مع العاملين بهدف نطوير منظومة العمل فى ضوء المستجدات.

- قلة حرص العاملون على تقديم المبادرات التى تسهم فى تحسين أداء العمل.

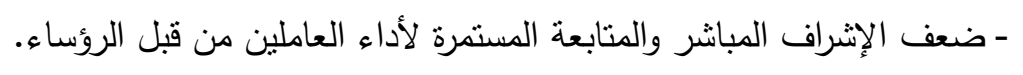
ثانياً : النتائج المتعلقة بواقع الثقة التنظيمية لدي العاملين بجامعة اسوان: 1. فيما يتعلق بواقع التقة التنظيمية بين العاملين والقيادات الجامعية: - ينم إختيار القيادات الجامعية طبقاً لقدرتهم واستعداداتهم. - تقدم القيادات الجامعية الدعم التنظيمى للعاملين بالجامعة.

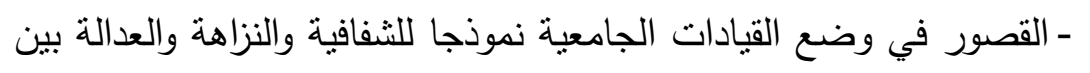

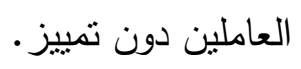

- قصور القيادات الجامعية في تقدير جهود وإسهامات العاملين بالجامعة. - القصور في اقامة وتوسيع الاتصالات بين جميع العاملين

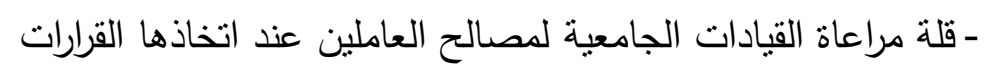
- قصور العلاقات الإنسانية بين العاملين بالجامعة. 
ـ قلة ثقة العاملين بالقيادات الجامعية بسبب جهلم بدقائق الأمور الخاصة

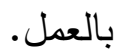
- قصور دور القيادات الجامعية في على التعرف على احتياجات العاملين التدريبية. - قصور توفر القيادات الجامعية للعاملين المعلومات اللازمة لأداء العمل

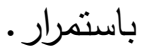
r. فيما يتعلق بواقع الثقة التتظيمية بين العاملين والمرؤوسين: - قلة الخبرات والمهارات التي يمتلكها الرئيس المباشر واللازمة التى تمكنه من الإدارة الفعالة للقسم. - قلة الفرص المتاحة للعاملين بالجامعة للمشاركة فى صنع القرارات المتعلقة بطرح البرامج التدربيية. - القصور في تقديم العون والإسناد من قِبل الرئيس المباشر للآخرين بعيدا عن الميول والاهواء والمصالح الثخصية - قلة تشجيع الرئيس المباشر للأفكار المبدعة التى تسهم فى تحسين مستوى أداء العاملين بالجامعة. - قصور الرئيس المباشر عن القيام بتوجيه العاملين فى الإتجاه السليم عند مواجهة أى مشكلة بالجامعة. - القصور في عقد الرئيس المباشر إجتماعات دورية لتبادل وجهات نظر العاملين بالجامعة حول العمل. - قلة اهتمام الرئيس المباشر بتعزيز نقاط الإتفاق مع الجميع والإبتعاد عن نقاط الإختلاف. ـ قلة اهتمام الرئيس المباشر بأولويات واحتياجات العاملين بالجامعة. - ضعف الثقة بين الرئيس المباشر والعاملين 
- يقوم الرئيس المباشر بمسامحة العاملين إذا أخطأوا أحياناً . r. فيما يتعلق بواقع الثقة التنظيمية بين العاملين وزملائهم: - قلة إخلاص بعض العاملين بالجامعة في أداء مهامهم الموكلة بتفانى وفاعلية.

- القصور في استجابة زملاء العمل بإهتمام عندما نطرح عليهم مشكلة فى العمل.

- القصور في تقديم العون والمساعدة للزملاء وبعضهم بدلاً من التركيز بشكل أكبر على أنفسهم. - مان. - ضعف تبادل الزملاء البيانات والمعلومات بشكل واضح لأداء العمل وحل المشكلات.

- أغلب الزملاء في العمل يقولون ما يؤمنون به أنفسهم وليس ما يحب أن بسمعه الأخرين. - قلة تفويض الزملاء لبعضهم في إتخاذ القرارات المناسبة للعمل فى حالة

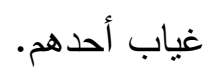
- ضعف التقة متبادلة بين الزملاء في العمل. - القصور في توجيه الزملاء لبعضهم البعض.

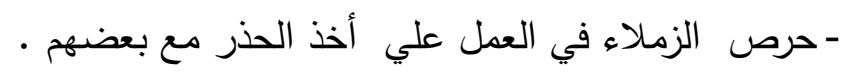

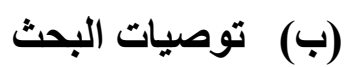

بناءً على ما سبق يستطيع البحث الحالي أن يقدم مجموعة من المقترحات،

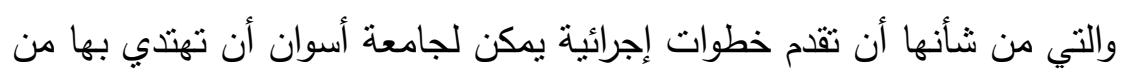

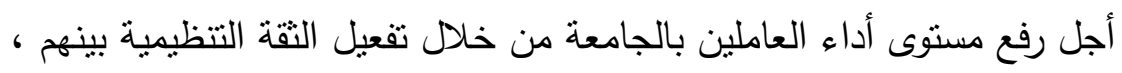

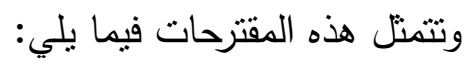

أولاً: التوصيات المتعلقة بتظوير الأداء الوظيفي لدي العاملين بجامعة أسوان: 
- إكساب العاملين بالجامعة المهارات المهنية والفنية اللازمة لتطوير العمل من خلال عقد دورات تدربيية لهم • - تدريب العاملين علي الأساليب الحديثة في تطوير العمل بالجامعة. - عقد دورات تدريبيه للعاملين بالجامعة وفقاً لاحتياجاتهم. - - زيادة رواتب العاملين بالجامعة وتقدير جهودهم في العمل. - تشجيع العاملين بالجامعة علي تحمل ساعات العمل الإضافي بالجامعة من خلال تقديم مكافآت مالية لهم. - تدريب العاملين بالجامعة علي إدارة الأزمات في العمل. - العمل علي تقييم أداء العاملين بصور مستمرة وفقاً لمعايير الجودة. - العمل علي مساعدة الزملاء لبعضهم البعض في حالة الخطأ في اداء العمل. - تشجيع العاملين علي غنجاز المهام المتطلبة منهم في الوقت المحدد. - تعريف العاملين بكيفية إستغلال الموارد والإمكانات المتاحة لديهم. - التتسيق والتعاون بين المستويات الإدارية لتحقيق جودة العمل. - عقد لقاءات دورية مع العاملين بالجامة بهدف تطوير منظومة العمل فى ضوء المستجدات الحديثة.

- تدعيم العاملون وتشجيعهم علي تقديم المبادرات التى تسهم فى تحسين أداء العمل. - الإشراف المستمر والمتابعة لأداء العاملين بالجامعة. ثانياً: التوصيات المتعلقة بتفعيل دور الثقة التنظيمية في تطوير الأداء الوظيفي لاي العاملين بجامعة اسوان: ا ـ تقعيل دور الثقة التظظيمية بين العاملين والقيادات الجامعية في تطوير الأداء - وضع معايير لإختيار القيادات الجامعية - - تقديم الدعم المادي والمعنوي للعاملين بالجامعة - تطبيق الثفافية والعدالة بين العاملين بالجامعة - تقدر جهود وإسهامات العاملين ومكافئهم عليها. 


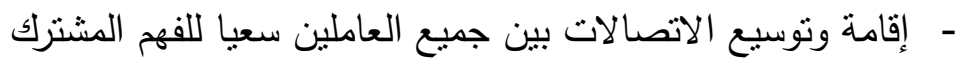

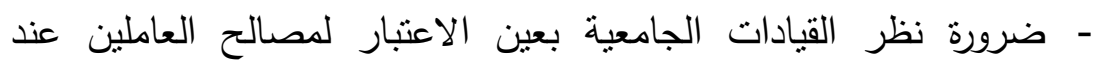

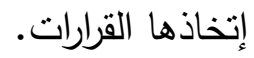

- العمل على سيادة مناخ من العلاقات الانسانية الطيبة داخل الجامعة.

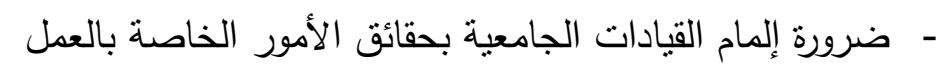
- قصور دور القيادات الجامعية في على التعرف على احتياجات العاملين

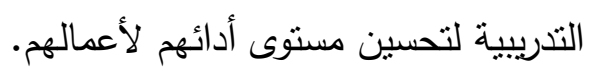
- - ضرورة توفر قاعدة بيانات اللازمة لأداء العمل بالجامعة.

r. تفعيل دور الثقة التنظيمية بين العاملين والمرؤوسين في تطوير الأداء:

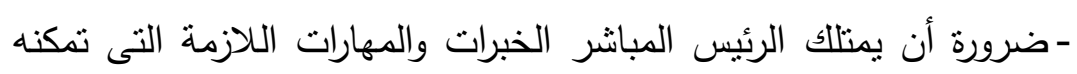

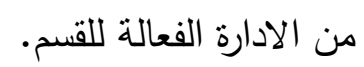
- إتاحة الفرصة للعاملين للمشاركة فى صنع القرارات المتعلقة بطرح البرامج التشريبية. - ضرورة أن يقام الرئيس المباشر العون والإسناد للآخرين بعيداً عن الميول والاهواء والمصالح الثخصية. - تشجيع الرئيس المباثر الأفكار المبدعة التى تسهم فى تحسين مستوى

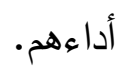
- قيام الرئيس المباشر بتوجيه العاملين فى الاتجاه السليم عند مواجهة اى مشكلة بالجامعة. - عقد الرئيس المبانر إجتماعات دورية لتبادل وجهات نظر العاملين بالجامعة حول العمل 
- سعى الرئيس المباشر دائما لتعزيز نقاط الاتفاق مع الجميع والابتعاد عن نقاط الاختلاف - اهتمام الرئيس المباشر بدرجة كبيرة بأولويات واحتياجات العاملين

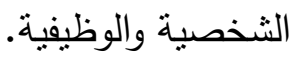
- ضرورة زيادة النقة بين الرئيس المباشر والعاملين بإعطاء مهام محددة

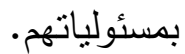
- ضرورة أن يقوم الرئيس المباشر بمسامحة العاملين إذا أخطأوا في حالة

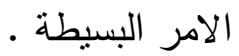
r. تفعيل دور التقة التنظيمية بين العاملين وزملائهم في تطوير الأداء : - الإخلاص لوجه اله في أداء العاملين للمهام الموكلة إليهم بتفانى وفاعلية.

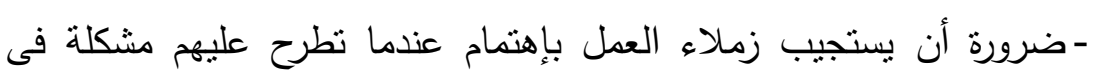

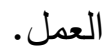

- اهتمام العاملين بتقديم العون والمساعدة لبعضهم بدلاً من التركيز بشكل أكبر على أنفسهم. - تبادل الزملاء البيانات والمعلومات بشكل واضح لأداء العمل وحل

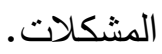
- ضرورة أن يحب الزملاء لغيرهم ما يحبونه لانفسهم.

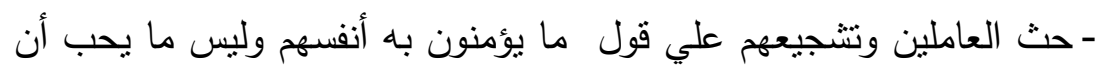

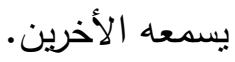

- ضرورة تفويض الزملاء لبعضهم في إتخاذ القرارات المناسبة للعمل فى حالة

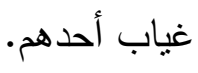
- ضرورة تواجد ثقة متبادلة بين الزملاء في العمل. - توجيه الزملاء لبعضهم البعض بالعمل. $-07$. 


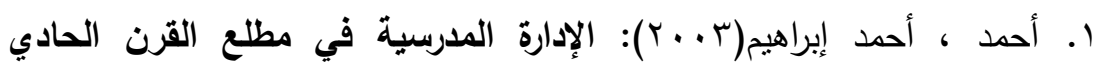
والعشرين ، القاهرة: دار الفكر العربي.

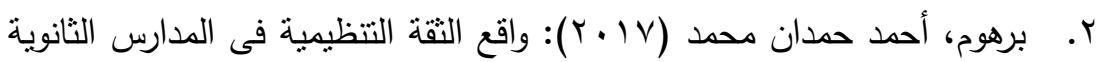

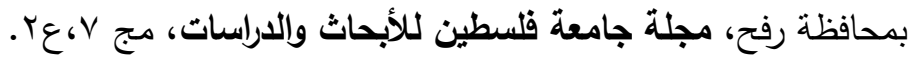
r. البلوي، محمد (^ . . ץ): التمكين الإداري وعلاقته بالأداء الوظيفي لدى معلمي المدارس الحكومية في محافظة الوجه بالمملكة العربية السعودية من وجهة نظرهم، رسالة ماجستير ، جامعة مؤتة، الكرك، الأردن.

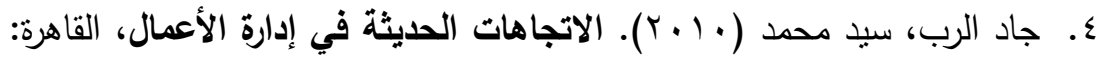
دار شتات للنشر والتوزيع. ه. الحردان، نسيم فلاح رفيفان (Y. V): درجة الذكاء العاطفى لمديرى المدارس الثانوية الحكومية وعلاقتها بالقة التظيمية للمعلمين من وجهة نظرهم فى العاصمة عمان، رسالة ماجستير ، جامعة الثرق الاوسط،كلية العلوم التربوية، قسم الادارة والمناهج. 7. حمدي، نظيمة(1/(r): درجة تقويض السلطة لدي عمداء الكليات الاكاديمية في الجامعات الأردنية وعلاقتها بكب من الثقة التنظيمية والأداء الوظيفي لدي رؤساء الأقسام فيها ، رسالة دكتوراه، جامعة عمان العربية، عمان: الأردن. V. حميد ، محمد عبد الله حس( ( 1 ب): تطوير الأداء البحثي للجامعات في ضوء الإدارة بالقيم ، كلية التربية، جامعة حجة، اليمن.

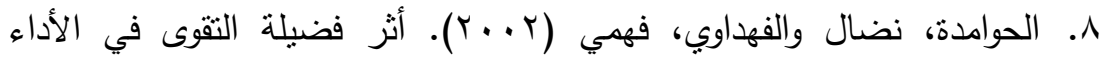
الوظيفي، مجلة مؤتة للبحوث والدراسات: سلسلة العلوم الإنسانية والاجتماعية، 


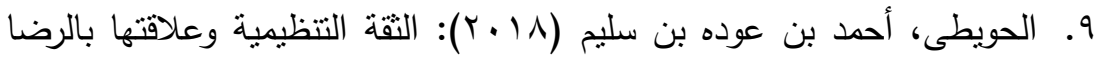
الوظيفى لدى معلمى المدارس الابتدائية الحكومية بمدينة تبوك، المجلة التريوية،

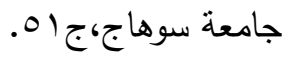

• ( . الحوامدة، نضال صالح (9 . . ץ): العلاقة بين مستوى ادراك فاعلية وعدالة نظام تقويم الاداء الوظيفى والرضا الوظيفى والولاء التنظيمى والثقة التظيمية فى

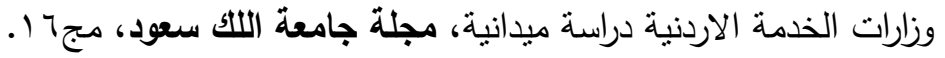

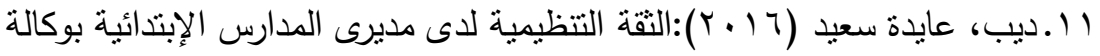

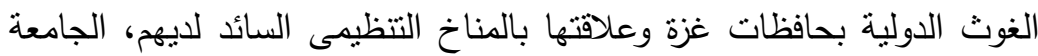
الاسلامية، غزة، رسالة ماجستير ، قسم اصول التربية. r ا. الربيق، محمد. "العوامل المؤثرة في فاعلية الأداء الوظيفي للقيادات الأمنية دراسة تطبيقية على الضباط الداخليين في قيادة أمن المنشآت والقوة الخاصة لأمن الطرق"، دراسة ماجستير ، أكاديمية نايف للعلوم الأمنية، السعودية، .$r \ldots$

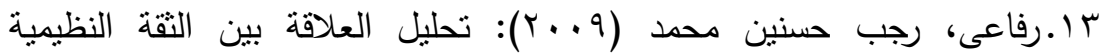

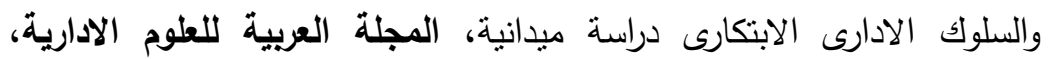

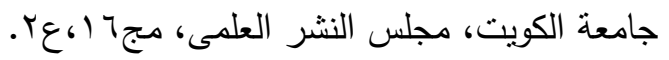
ع ا. السلمي ، علي (199 1): إدارة الموارد البشرية، القاهرة : مكتبة غريب. 1 ا.سميع، زيد صالح حسن(9 . . ץ): "أثز الثقافة التظظيمية على الأداء الوظيفي"، رسائة ماجستير، جامعة حلوان، اليمن.

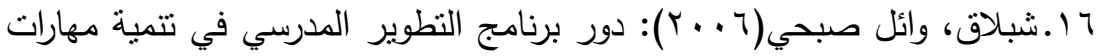
التخطيط لدي مديري المدارس الثانوية ، رسالة ماجستير ، كلية التربية ، الجامعة الاسلامية ، غزة. 
V I. الثريف، طلال عبد الملك (ع . ب): الأنماط القيادية وعلاقتها بالأداء الوظيفي

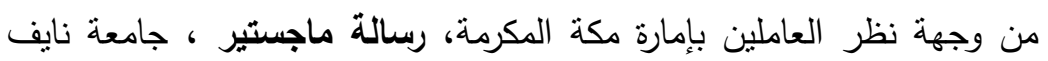

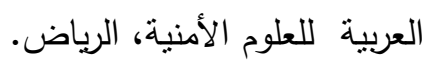

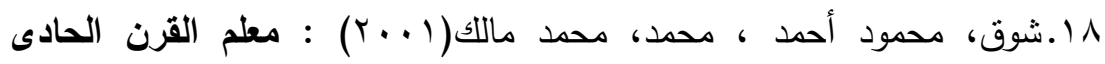
والعشرين ، القاهرة: دار الفكر العربى •

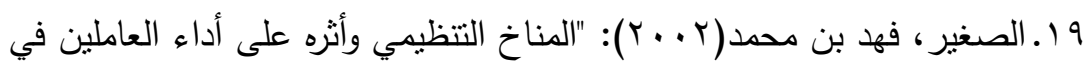
الأجهز ة الأمنية" . رسالة ماجستير ، جامعة نايف العربية للعلوم الأمنية. •r. الصقير، عبد المحسن بن محمد بن عبداله (£ ا.ب):ممارسة مديرى مدارس التعليم العام بمنطقة القصيم للصلاحيات الإدارية المنوحة وعلاقتها بالثقة

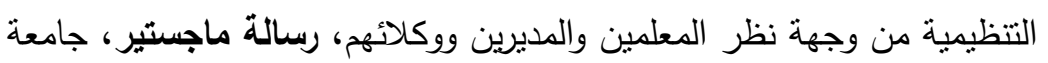
أم القرى ، كلية التربية قسم الادارة التربوية والتخطيط.

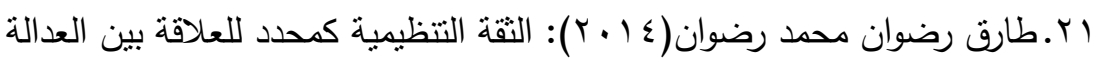

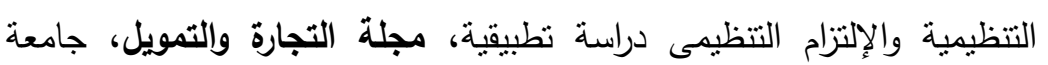
طنطا،ع:

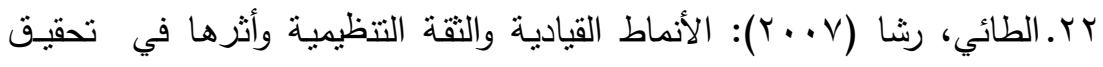

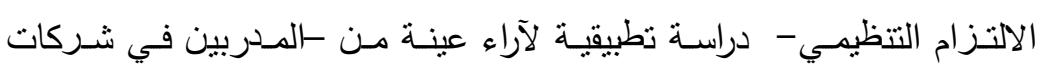

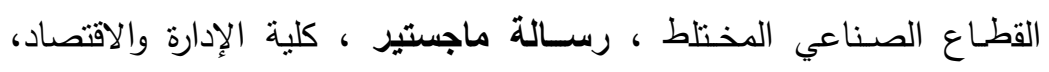

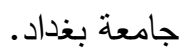

rץ.الطريف، خالد بن حمد (10 ب): افضل الممارسات لتتبع مستوى الثقة

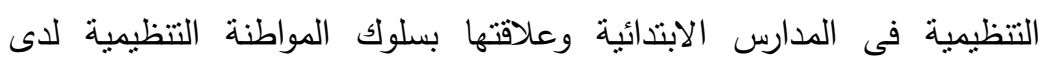

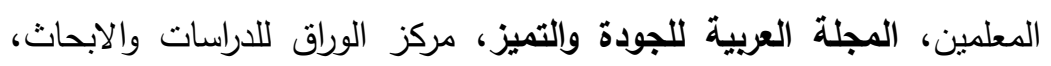

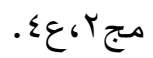


צY.العاجز، فؤاد علي ، نشوان، جميل: تطوير أداء المعلمين في ضوء برنامج الدرسة كمركز تطوير التابع لوكالة الغوث الدولية بغزة، بحث مقدم للمؤتمر

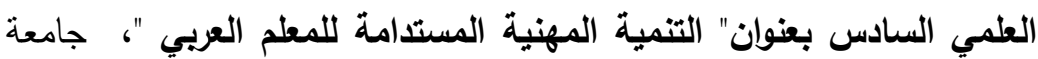

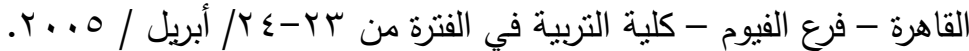

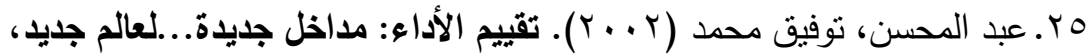
بيروت: دار الفكر العربي والنهضة العربية.

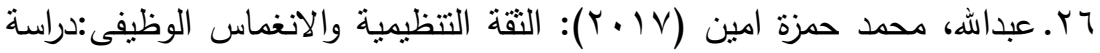
ميدانية بجامعة بنى سويف، مجلة كلية الآداب، جامعة طنطا،ع • r،جr.

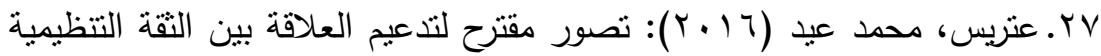
والولاء التظظيمى لدى اعضاء هيئة التنريس وعاونيهم بكلية التربية جامعة

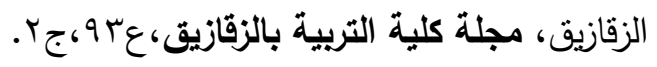

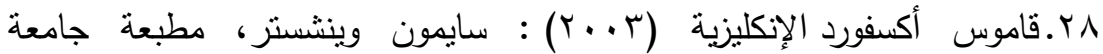

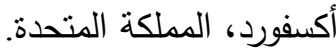

9.r.محد بن ابي بكر الرازي: مختار الصحاح..

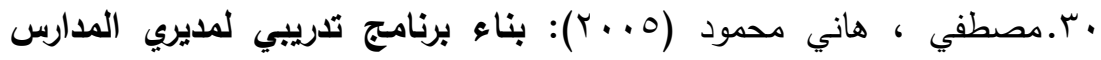

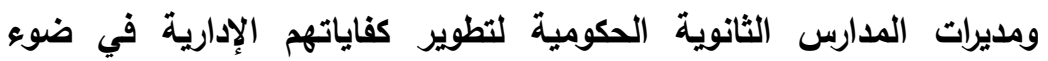
احتياجاتهم التدريبية، عمان: دار جرير للنشر والتوزيع.

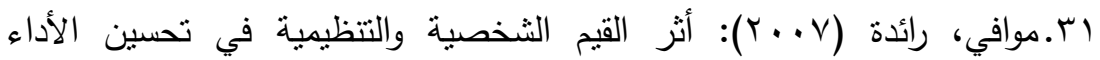

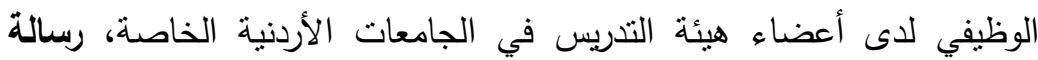
ماجستير، جامعة مؤته، الكرك، الأردن.

32. Hoppes, C,\&Holley, K(2014): .Organizational trust in times of challenge: the impact on faculty and administrators .Innovative Higher Education .39 (3): 201 - 216 
33. James, H . (2010) “A Study Organizational Trust and Related Variable Among Faculty Members at HBUCS".Unpublished Ph.D. Dissertation. The University of Iowa.

34. adams,b. et al(2008): organizational trust in the canadianforces, defense research and development, Canada Toronto.

35. Daft, Richard(2001): Organization Theory and Design, South western college publishing, Ohio.

36. sonerpolat(2013): the impact of teacher's organization trust, perception on organizational cynicism perception, journal science research-journals,issu, vol.1,no.1.

37. Chair, ebrahim alnoor, Stephenson max (2004) : Trust, Social Capital, and Organizational Effectiveness,Major paper submitted to the Faculty of the Virginia Polytechnic Institute and State University in partial fulfillment, degree of Master of Public and International Affairs, Blacksburg, VA.

38. Boe,tammy A,(2002): gaining and/or maintaining employee trust within service organizations, a research paper submitted in partial fulfillment of the, requirements for the master of science degree in training and development, University of Wisconsin-Stout August.

39. Bagraim,Jeffrey j,hime,patricia(2007):the dimensionality of workplace interpersonal trust and its relationship to workplace affective commitment, jounal of industrial psychology ,vol33, no.3.

40. PORUMBESCU, Greg, PARK, Jungho, Peter OOMSELS (2013) :building trust communication and subordinate trust in public organizations, Transylvanian review of administrative sciences, Volume: 38.

41. Robbins Stephen p(2003):organizational behavior,10th ed, prentice hall person education international, upper saddle river, new jersey.b.thesis's\&studies. 
42. Mourd, Mansour(2014):organization,justice,support and trust :evidence from saudia companies, journal of economic, business and management, vol.2,no.1.

43. Kort,katarzyna and lewicka,dagmara(2012):the importance of trust in manager-imployee reelationships, international journal electronic business management,vol.10,no.3.

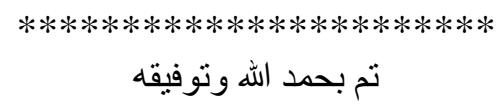

